UNIVERSIDADE DE BRASÍLIA

FACULDADE DE TECNOLOGIA

DEPARTAMENTO DE ENGENHARIA CIVIL E AMBIENTAL

DISSERTAÇÃO DE MESTRADO EM TRANSPORTES

CARACTERIZAÇÃO DOS FATORES CONTRIBUINTES EM ACIDENTES DE PEQUENAS AERONAVES DA AVIAÇÃO GERAL BRASILEIRA UTILIZANDO INTELIGÊNCIA ARTIFICIAL

RAFAEL MEDEIROS HESPANHOL ORIENTADOR: JOSÉ AUGUSTO ABREU SÁ FORTES CO-ORIENTADOR: DANILLO ROBERTO PEREIRA

BRASÍLIA / DF: 02/2016 


\author{
UNIVERSIDADE DE BRASÍLIA \\ FACULDADE DE TECNOLOGIA \\ DEPARTAMENTO DE ENGENHARIA CIVIL E AMBIENTAL
}

\title{
CARACTERIZAÇÃO DOS FATORES CONTRIBUINTES EM ACIDENTES DE PEQUENAS AERONAVES DA AVIAÇÃO GERAL BRASILEIRA UTILIZANDO INTELIGÊNCIA ARTIFICIAL
}

\section{RAFAEL MEDEIROS HESPANHOL}

DiSSERTAÇÃO SUBMETIDA AO PROGRAMA DE PÓS-GRADUAÇÃO EM TRANSPORTES DO DEPARTAMENTO DE ENGENHARIA CIVIL E AMBIENTAL DA UNIVERSIDADE DE BRASÍLIA.

APROVADA POR:

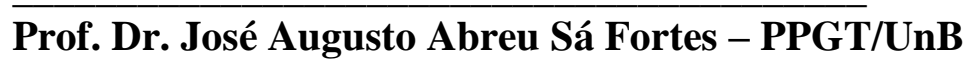
(ORIENTADOR)

$\overline{\text { Prof. Dr. Pastor Willy Gonzales Taco - PPGT/UnB }}$ (EXAMINADOR I)

Prof. Dr. Adyr da Silva - ITA BRASIL (EXAMINADOR II) 


\section{FICHA CATALOGRÁFICA}
HESPANHOL, RAFAEL MEDEIROS Caracterização dos fatores contribuintes em acidentes de pequenas aeronaves da aviação
geral brasileira utilizando inteligência artificial [Distrito Federal] 2016.
xiv, 82p., 210 x $297 \mathrm{~mm}$ (ENC/FT/UnB, Mestre, Transportes, 2016).
Dissertação de Mestrado - Universidade de Brasília. Faculdade de Tecnologia.
Departamento de Engenharia Civil e Ambiental.
1. Aviação Geral
3. Classificação de Padrões
2. Acidentes
4. Floresta de Caminhos Ótimos
I. ENC/FT/UnB
II. Título (série)

\section{REFERÊNCIA BIBLIOGRÁFICA}

HESPANHOL, R. M. (2016). Caracterização dos fatores contribuintes em acidentes de pequenas aeronaves da aviação geral brasileira utilizando inteligência artificial. Dissertação de Mestrado em Transportes, Publicação T.DM-001/2016, Departamento de Engenharia Civil e Ambiental, Faculdade de Tecnologia, Universidade de Brasília, DF, 82p.

\section{CESSÃO DE DIREITOS}

AUTOR: Rafael Medeiros Hespanhol

TÍTULO: Caracterização dos fatores contribuintes em acidentes de pequenas aeronaves da aviação geral brasileira utilizando inteligência artificial

GRAU: Mestre

ANO: 2016

É concedida à Universidade de Brasília permissão para reproduzir cópias desta dissertação de mestre e para emprestar ou vender tais cópias somente para propósitos acadêmicos e científicos. $\mathrm{O}$ autor reserva outros direitos de publicação e nenhuma parte dessa dissertação de mestrado pode ser reproduzida sem autorização por escrito do autor.

Rafael Medeiros Hespanhol

vooehes@gmail.com

Rua Eufrásio Toledo, 149 - Jardim Marupiara

Presidente Prudente - São Paulo 
"Quando camminerete sulla terra dopo aver volato, guarderete il cielo perché là siete stati e là vorrete tornare."

Leonardo da Vinci 


\section{DEDICATÓRIA}

À Cauan Michelino (in memoriam) e Murilo Péscuma (in memoriam). 


\section{AGRADECIMENTOS}

Aos meus pais, professores Nivaldo e Rosângela, por terem sido meus orientadores desde o primeiro dia de vida. A eles agradeço especialmente por sempre me conduzirem e apoiarem mesmo nos projetos com os quais não concordavam. Também a meus irmãos, Thales e Lorena, pela paciência em nossas inúmeras diferenças.

Aos meus primos César e Andrea, por fazerem de Goiânia a minha segunda casa. Terei sempre na lembrança todo o apoio e carinho recebido deles nos momentos difíceis e de comemoração; e aos meus padrinhos Wilson e Florinda, a quem tenho como pais, pela torcida, suporte e atenção sempre dispendidos com o maior amor possível.

Ao professor e orientador José Augusto, por acreditar, confiar e me orientar desde nosso primeiro contato por e-mail. Sua atenção foi peça-chave na motivação em me mudar à Brasília antes mesmo de saber onde se localizava a Asa Norte. A ele também agradeço pela oportunidade de participar nos SIMTs e nas aulas da graduação - ambas as experiências acrescentaram "créditos" impossíveis de serem quantificados.

Ao meu coorientador e amigo Danillo, pela disposição e paciência em dispor de seu tempo em me apresentar ideias novas, e pelas esfirras de carne do coruja nos momentos de desespero com o aprendizado de máquina.

À Patrícia, por todo suporte, carinho, insistência, companheirismo e, sobretudo, parceria absoluta no desenvolvimento desse trabalho.

À minha família Hespanhol: tios-avós e tias-avós, pelo apoio independente da compreensão sobre o momento; tios Beto e Lúcia, pelo aconchego da terra vermelha; e a meu avô, Pedro Hespanhol (in memorium), por toda a sabedoria de seus silêncios.

Aos prudentinos: André, pelos tererés; Dino, pelas caminhadas; Bia, por ser tudo o que é; Júnior, pelos pitis; Gabriel, pela falta de noção; Karen, pelas gargalhadas; Bhea e Wagner, pelos programas de índio; Rafael Montes, pelas cervejas e especulações; Gui, pela parceria e acolhimento; minha prima Letícia, pelo cuidado e animação de sempre; Everton e Flávia, pelos churrascos alongados; Mano, pela confiança acadêmica; e Carol Clemente, por sua simpatia cavalar.

Aos amigos da UNESP: Victão e Mari, pelo aconchego constante em seu lar; Bussa, por todo o auxílio nos cálculos de engenharia de nuvens; Barata, pelos rolos acumulados; Junão pela 
implicância constante; Simpatia, por seu gigantesco coração; e professor e amigo Marcelo Magalhães, pela participação direta e efetiva durante toda essa caminhada acadêmica.

Às famílias que me adotam: Mazinho, Eveli, Du, Ito, Gui, Léia e Théo Alberti, por me encherem de fé constantemente; João e Nilda Reginato, pelos almoços, fretes e risadas de sempre; Abílio e Sônia, pela loucura dessa "grande família"; Alba e J. Arana, por me suportarem todos os finais de semana; Renato, Simone, Valdir e Maria Ortelan, por serem sempre refúgio em meio à correria paulistana; Comandante Zé e Lorença Clemente, e Dequielle e Augusto Garcia, por todo o carinho e torcida desde a adolescência; e Marcão e Nilza Torcato, pelos abraços sempre acolhedores.

Aos amigos do PPGT: Marcello, por compartilhar das mesmas indignações; Guilherme, pela parceria em trabalhos, cervejas e amendoins; Robert, pelas implicâncias; Rafael, por me mostrar que existe esperança para a Anac; Paranaíba, por fazer reviver minha opinião política; Paulão, pela energia e alegria invejáveis; Gi, por ser a companheira de sala mais materna e paranaense que poderia encontrar em Brasília; minhas "chefas" paraenses, Thárcia e Luca, por toda ajuda nos momentos de maior desespero; Camila e diva Lucinete, por sempre quebrarem todos os galhos possíveis e imagináveis; Chris, pela companhia sempre agradável; meus queridos coorientadores não-oficiais, Abimael, Pierre e Paulinha, pelo apoio além do trabalho e por todas as discussões em que me deram o prazer de sair derrotado - espero continuar aprendendo com todos durante os anos que se seguirem; e a todos os professores que se disponibilizaram em passar seus conhecimentos em algum momento dessa jornada, em especial à Michelle Andrade, Pastor Willy e Paulo César, que muito contribuíram com esse trabalho.

Ao pessoal da Unoeste: meus alunos, por me ensinarem tanto todos os dias; colegas professores, em especial à minha coordenadora professora Clara, pela compreensão durante o período final de escrita dessa dissertação; e ao professor Creste, pela confiança depositada em minha contratação.

Aos comandantes: Lucas, pela amizade e conhecimento compartilhado; José Clemente, pelas conversas regadas à sabedoria; Urbano, pelo carinho e confiança; Marcos Marchese, por me mostrar que o conhecimento não tem limites; Helinho, por simplificar tudo o que pode parecer complicado; Cláudio Caraffa, pela confiança e motivação nos momentos mais difíceis; e ao Ten-Cel Aviador Rubens, por todo o suporte durante o desenvolvimento desse trabalho. 


\section{RESUMO}

Segurança de voo significa diminuir e gerenciar, tanto quanto possível, o risco de lesões às pessoas ou danos aos bens materiais, portanto, consideram-se necessários estudos que sirvam de base para a prevenção de novos acidentes, visto que esses acontecimentos podem provocar altos gastos de valores financeiros e a perda de vidas humanas. Partindo da teoria do "queijo suíço" de James Reason, buscaram-se analisar, por meio de inteligência artificial, os padrões de características, como por exemplo, fatores contribuintes dos acidentes da aviação geral no período de 2005 a 2013, com base nos relatórios emitidos pelo Centro de Investigação e Prevenção de Acidentes Aeronáuticos (Cenipa), utilizando-se aprendizado de máquina, por meio do classificador de padrões conhecido como OPF (Floresta de Caminhos Ótimos). Foram analisadas relações entre características como, por exemplo, experiência total, experiência na aeronave do acidente, experiência recente e nível de qualificação do piloto, aspectos e quantidade total de fatores contribuintes, quantidade de motores da aeronave, quantidade de fatores indeterminados, presença de copiloto, e fatalidade, totalizando 49 relações que também foram avaliadas por meio dos testes estatísticos, a fim de se testar a robustez do método OPF. Nos casos em que se tiveram resultados robustos as análises foram realizadas pelo viés da segurança de voo e dos padrões encontrados. Nos casos em que não se obtiveram resultados robustos, foram analisadas possíveis adequações e melhorias na aplicação do método, buscando explicar a que o pesquisador deve se atentar ao organizar e aplicar o OPF em sua base de dados. Complementarmente, realizaram-se análises sobre os relatórios de acidentes com base no que se notou durante a extração dos dados ressaltando, sobretudo, casos e eventos que devem ser mais bem observados pelo órgão investigador sobre seus métodos de elaboração de relatórios e sobre sua imparcialidade. A importância de se discutir os padrões dos acidentes se mostrou evidente visto que alguns perfis de pilotos necessitam de mais atenção quanto a algumas características (motorização da aeronave ou suas ações, por exemplo) quanto à segurança de voo, concluindo que, de maneira geral, se obtiveram bons resultados com o OPF, encontrando padrões que não seriam possíveis de serem identificados por meio de correlação estatística.

Palavras-chave: Aviação Geral, Acidentes Aeronáuticos, Classificação de Padrões, Floresta de Caminhos Ótimos. 


\section{ABSTRACT}

Flight safety means reducing and managing the risk of personal injuries or material goods damage to material goods as much as possible, therefore, it's considered necessary studies serving as a basis for preventing new accidents, since these events can cause high expenses in financial values and the loss of human lives. Departing from the "swiss cheese" theory of James Reason, different assessments were conducted, through artificial intelligence, regarding aspects and characteristics patterns of general aviation accidents between 2005 and 2013, based on the reports from the investigative body, using a machine learning pattern classifier known as OPF (Optimum-Path Forest). Examples of characteristics that were analyzed are total experience, experience in the aircraft of the accident, recent experience, qualification level, aspects of the contributing factors, the total amount of contributing factors, number of engines, number of uncertain factors, engine type, presence of co-pilot, and fatality, amounting 49 possibilities that were also assessed by means of statistical tests in order to analyze the robustness of the OPF method. Analyzes were performed at the robust results, by the bias of flight safety considering the patterns found. In the results that did not obtain robust results, it was analyzed possible adjustments and improvements in the application of this method, in order to explain what the investigator should be alert when organizing and applying the OPF on a database. As a complement analysis, some aspects which were noticed at accident reports during the data extraction emphasizing, specially, cases and events that should be better observed by the investigative body about their reporting methods and about its impartiality. The value of discussing the patterns of characteristics clearly proved that some pilots profiles require more attention regarding some characteristics (engine of the aircraft or its actions, for example) about flight safety, concluding that, in general, it's possible to have good results with OPF, finding patterns beyond the statistical correlation.

Keywords: General Aviation, Aviation Accidents, Pattern Classification, Optimum-Path Forest. 


\section{ÍNDICE}

1 - INTRODUÇÃO

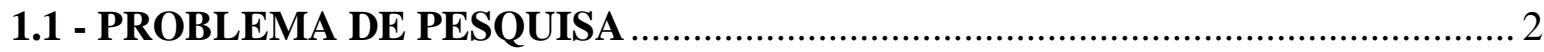

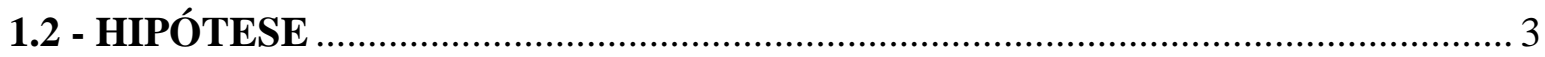

1.3 - OBJETIVOS

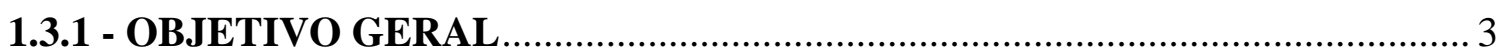

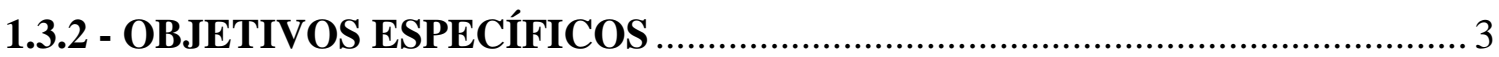

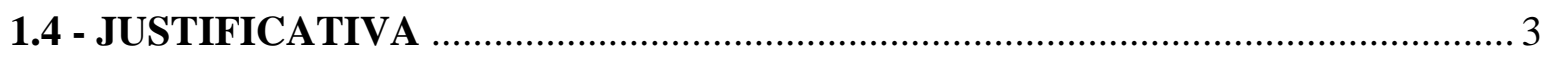

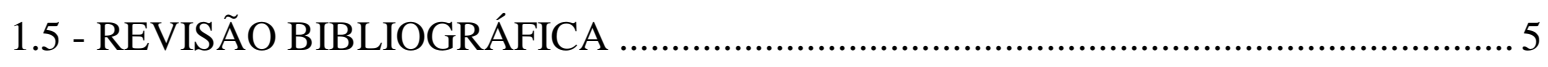

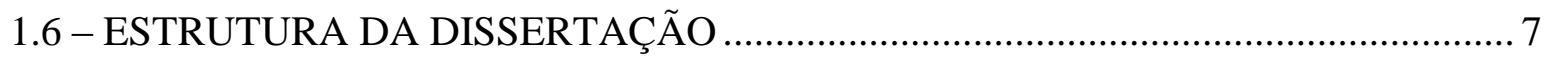

2 - SEGURANÇA DE VOO NA AVIAÇÃO GERAL NO BRASIL .................................. 8

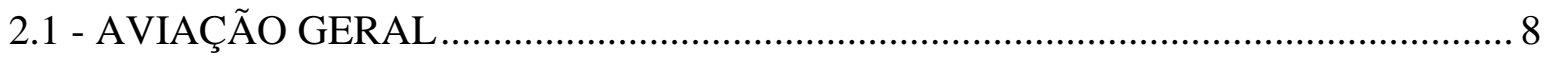

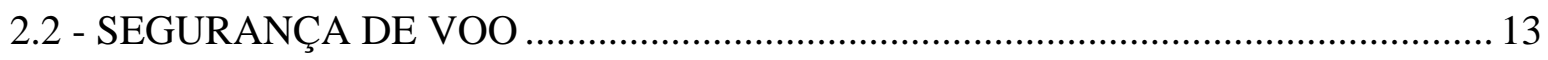

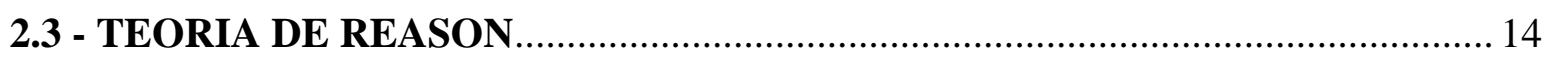

2.4 - FATORES CONTRIBUINTES EM ACIDENTES AERONÁUTICOS.................15

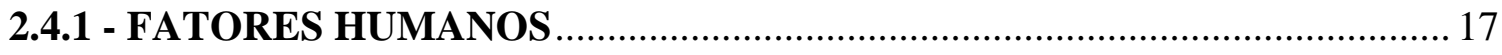

2.5 - RELATÓRIOS DE ACIDENTES AERONÁUTICOS …………………………..... 21

2.6 - SEGURANÇA DE VOO NA AVIAÇÃO GERAL ………………………......... 22

2.7 - ELEMENTO HUMANO "PILOTO” NA AVIAÇÃO GERAL .................................... 22

3 - FERRAMENTAS, PROCEDIMENTOS E MÉTODOS ............................................... 24

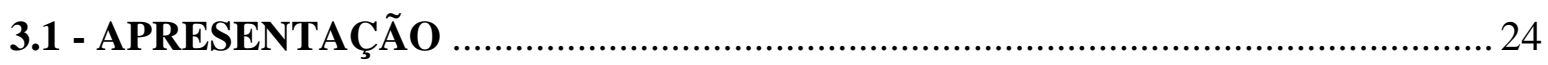

3.2 - COLETA E ORGANIZAÇÃO DE DADOS DOS ACIDENTES ……………….... 24

3.2.1 - LEVANTAMENTO DOS REGISTROS DE ACIDENTES DA AVIAÇÃO

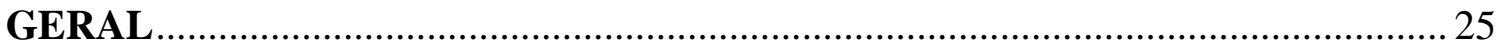

3.2.2 - ANÁLISE DA DISPONIBILIDADE DOS RELATÓRIOS FINAIS ……...... 28

3.2.3 - COLETA E ORGANIZAÇÃO DE DADOS DOS RELATÓRIOS FINAIS . 29

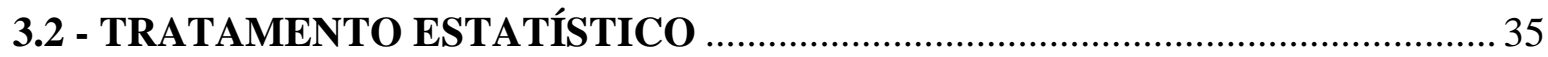

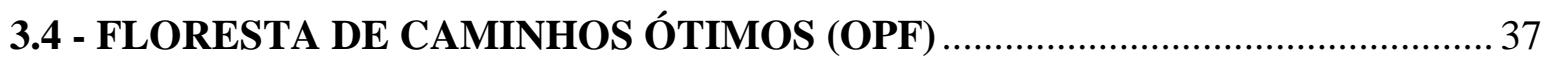

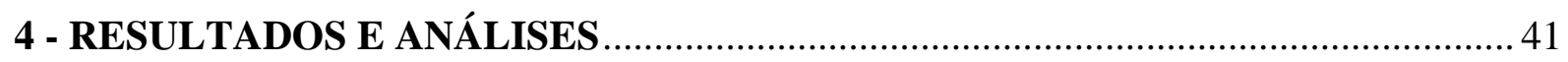

4.1 - RESULTADOS ROBUSTOS DO OPF.......................................................... 9

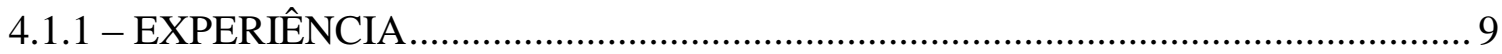

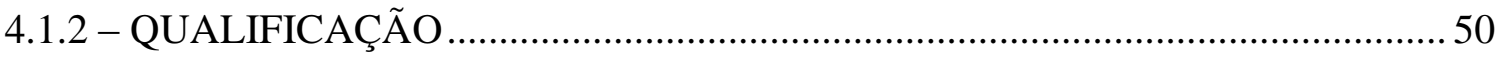




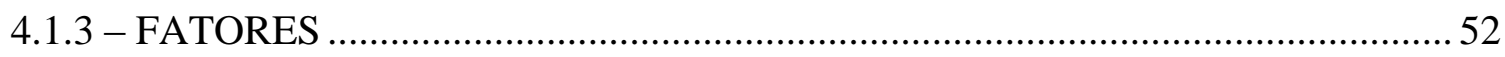

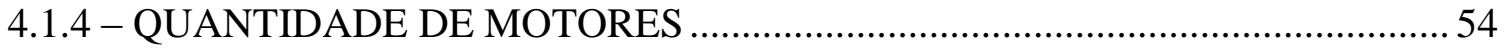

4.2 - POSSIBILIDADES DE MELHORIA NA APLICAÇÃO DO OPF........................... 55

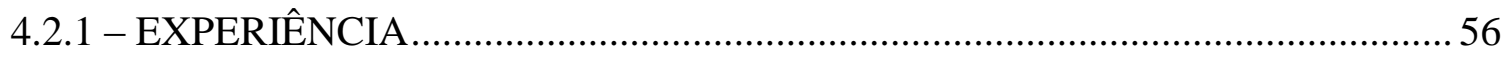

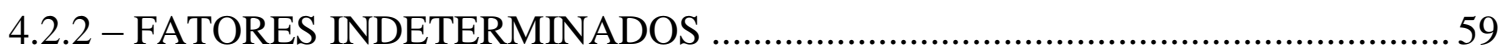

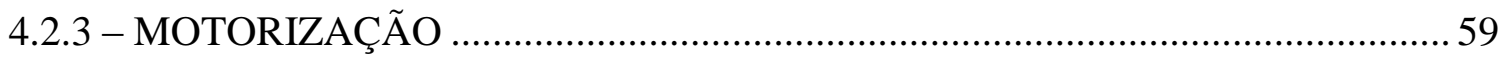

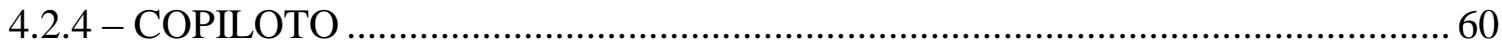

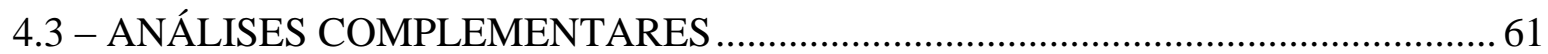

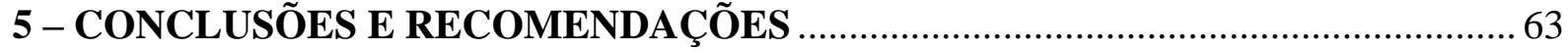

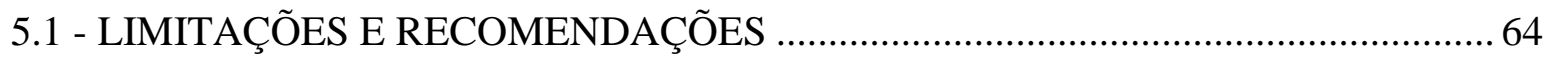

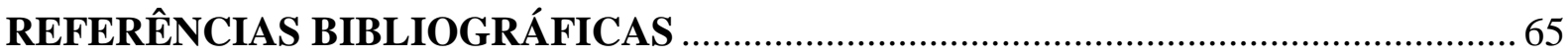

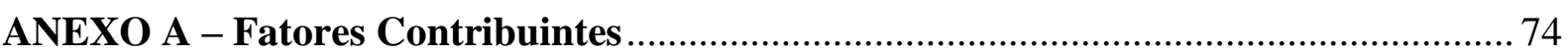

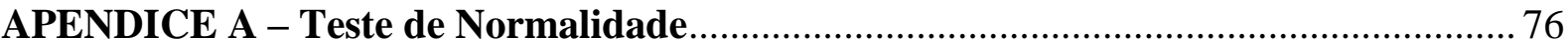

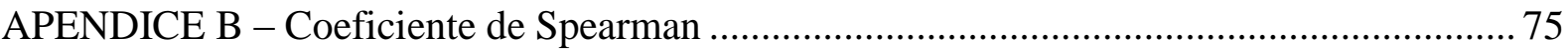

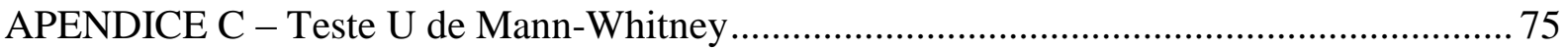

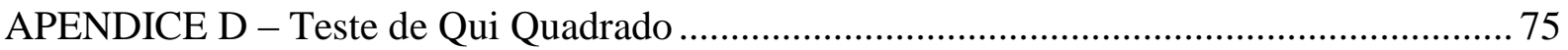

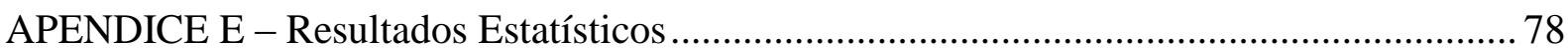




\section{LISTA DE TABELAS}

$\mathbf{N}^{\circ}$

Pág.

3.1 Quantidade de Relatórios Finais por Ano 


\section{LISTA DE QUADROS}

1.1 Termos combinados com algoritmos booleanos

3.1 Categorias de experiência

4.1 Padrões para nível baixo de experiência total com 25 caminhos

4.2 Padrão para nível médio de experiência total com 75 e 100 caminhos

4.3 Padrões dos tipos de fatores para baixa experiência na aeronave do acidente com 25 caminhos

4.4 Padrão dos tipos de fatores para média experiência na aeronave do acidente com 25 caminhos

4.5 Padrão dos tipos de fatores para elevada experiência na aeronave do acidente com 25 caminhos

4.6 Padrão dos tipos de fatores para elevada experiência recente com 25 caminhos

4.7 Padrões dos tipos de fatores para média experiência recente com 25 caminhos

4.8 Padrão dos tipos de fatores para baixa experiência recente com 25 caminhos

4.9 Padrão dos tipos de fatores para qualificação "Piloto Privado" com 75 caminhos

4.10 Padrão dos tipos de fatores para qualificação "Tipo" com 75 caminhos

4.11 Padrão dos tipos de fatores para qualificação "Tipo" com 100 caminhos

4.12 Padrões dos tipos de fatores em relação à fatalidade do acidente com 75 caminhos

4.13 Padrões de experiência dos pilotos com 25 caminhos

A.1.a Fatores contribuintes

A.1.b Teste de Normalidade Kolmogorov-Smirnov 76

B.1 Variáveis analisadas pelo Coeficiente de Spearman 77

C.1 Variáveis analisadas pelo Teste U de Mann-Whitney 78

D.1 Variáveis analisadas pelo Teste de Qui Quadrado 79

E.1 Resultados com o Coeficiente de Spearman 80

E.2 Resultados com o Teste U de Mann-Whitney 81

E.3 Resultados com o Teste de Qui Quadrado $\left(\mathrm{X}^{2}\right) \quad 82$ 


\section{LISTA DE FIGURAS}

$\mathbf{N}^{\mathbf{o}}$

Pág.

$\begin{array}{lll}1.1 & \text { Estrutura da Dissertação } & 07\end{array}$

$\begin{array}{lll}2.1 & \text { Cessna Citation X } & 10\end{array}$

2.2 Beechcraft King Air C90 GTX 11

2.3 Piper Seneca V 11

2.4 Composição da frota da Aviação Geral 12

2.5 Idade da frota de aviões à pistão em 2012 (em anos) 14

2.6 Esquema da Teoria do Queijo Suíço 15

2.7 Mapa mental dos aspectos dos fatores contribuintes 16

2.7 Primeiro nível do método HFACS 18

2.8 Segundo nível do método HFACS 19

2.9 Terceiro nível do método HFACS 20

2.10 Quarto nível do método HFACS 21

2.11 Quantidade de acidentes em 2013 por categoria 22

2.12 Modelo SHELL 23

3.1 Helicóptero AS365 N3+ 26

3.2 Motoplanador ASH $26 \quad 26$

3.3 Motor a Jato 26

3.4 Motor turbo-fan $\quad 26$

3.5 EMB202A Ipanema $\quad 27$

$\begin{array}{lll}3.6 & \text { AT-802A } & 27\end{array}$

3.7 Quantidade de Relatórios por Etapa 28

3.8 Conjunto inicial de dados em 2D 39

3.9 Conjunto de dados em processamento em 2D 40

3.10 Conjunto de dados processados em 2D 40

4.1 Mapa mental dos resultados e análises $\quad 42$ 


\section{1 - INTRODUÇÃO}

Nas últimas décadas, o setor aéreo assumiu papel de destaque na integração de diferentes países e mercados. Juntamente com a evolução tecnológica em áreas como comunicação e informática, pode-se considerar que o transporte aéreo facilitou a globalização (Castles, 2002).

No Brasil, a aviação apresentou expressivo crescimento, especialmente a partir de 2001 com a liberalização tarifária (Da Silva, 2008), tendo participação cada vez maior na economia do país, com aumento significativo tanto da movimentação e número de aeronaves, quanto do volume de carga e número de passageiros transportados (Salgado, 2009; Salgado et al., 2010; Mckinsey \& Company do Brasil, 2010; Brasil, 2012a; Brasil, 2014a).

A aviação geral (executiva) se constitui numa das categorias de transporte aéreo e engloba desde modelos conhecidos por "jatos" e turboélices até aviões convencionais (movidos pelo conjunto pistão-hélice), usados tanto para o transporte quanto para o lazer (Abag, 2013a). Essa categoria possui características técnicas, operacionais e regulatórias muito distintas da aviação regular (conhecida pelas linhas aéreas regulares) por atender, por exemplo, uma parcela restrita da população com interesse e capacidade financeira de pagar por um transporte extremamente específico (Santi, 2009).

Apesar de não ser um transporte público, a aviação geral possui grande relevância para o desenvolvimento do país. Tal categoria se mostra como alternativa para transportar com rapidez pessoas em viagens de urgência, profissionais com alto nível de qualificação ou investidores em viagens de negócio, sendo, portanto, uma atividade econômica de interesse público (Stolt \& Ensslin, 2009).

A aviação geral também é importante para a integração entre regiões, culturas e sociedades, devido à sua capacidade de conectar fisicamente praticamente qualquer localidade do Brasil e do mundo, característica reconhecida pelas autoridades apenas nos últimos anos. Enquanto a aviação regular atende pouco mais de 130 localidades dos 5.565 municípios brasileiros, a aviação geral atua em cerca de três mil aeródromos em todo o país (Abag, 2013a).

Uma cultura que garante o crescimento da aviação ao longo do tempo é também um dos preceitos mais importantes e antigos em setores aeronáuticos: a segurança de voo. Esse termo significa diminuir e gerenciar, tanto quanto possível, o risco de lesões às pessoas ou danos aos bens materiais (OACI, 2013). A prevenção é considerada, portanto, um investimento necessário, visto que as consequências de um acidente podem provocar não apenas o gasto de altos valores financeiros, mas também a perda de vidas humanas. Para que essa prevenção seja efetiva, todos os profissionais e organizações integrantes do sistema aeronáutico devem ser envolvidos nas ações de conscientização, independente de estarem ligados ao planejamento, gerenciamento, operação ou suporte. 
Quanto aos acidentes aeronáuticos brasileiros, o Centro de Investigação e Prevenção de Acidentes (Cenipa), órgão do Comando da Aeronáutica responsável pela investigação de acidentes civis e militares, constatou que no período entre 2003 e 2012, os acidentes na aviação geral ocorreram em número proporcionalmente superior a outras categorias de transporte de passageiros. Exemplo disso são os acidentes do tipo "falha de motor em voo", que representaram aproximadamente $23 \%$ dos acidentes na aviação geral, enquanto que na aviação regular esse percentual foi de apenas $5 \%$.

Para diminuir esses acidentes aéreos, faz-se necessário reduzir seus principais precedentes e fatores contribuintes, considerando as características e peculiaridades desse segmento da aviação civil, visando seu pleno desenvolvimento. O Cenipa agrupa os fatores contribuintes para acidentes aeronáuticos em: humanos, materiais e operacionais (Santi, 2009; Brasil, 2011), sendo que na aviação geral no país, os fatores humanos e operacionais são responsáveis pela maior parte dos acidentes (Brasil, 2013, 2015b).

No presente trabalho, parte-se do pressuposto de que um bom piloto é aquele que possui conhecimento suficiente para julgar situações apropriadamente. Exemplo disso seria o comportamento em uma situação de pane, a supervisão da aeronave e dos procedimentos executados antes do voo, a correta coordenação entre a tripulação, além da operação do equipamento (avião e seus sistemas). Considera-se, portanto, que dedicar atenção ao fator humano da aviação geral pode ser uma medida válida para reduzir a incidência dos fatores humanos e operacionais que provocam acidentes.

Considerando a grande quantidade de informações contida nos relatórios finais de acidentes aeronáuticos e a riqueza de seu conteúdo, explorá-los a fundo e buscar extrair medidas preventivas é uma oportunidade que dificilmente seria possível em outros modos de transporte, como o rodoviário, por exemplo. Para extrair essas informações de maneira imparcial e identificar os padrões dos acidentes, utilizou-se do método classificador de padrões conhecido como Floresta de Caminhos Ótimos (OPF) (Papa, 2008),

Procurou-se no presente trabalho, encontrar informações que possam fomentar políticas ligadas, por exemplo, as novas exigências de treinamento ou experiência, levando em conta que a melhoria na capacitação dos recursos humanos, em especial os pilotos, pode ser considerada uma medida relativamente simples e essencial para aumentar consideravelmente a segurança da operação na aviação (Benson, 1998; Gillingham \& Previc, 1996; Santi, 2009).

\section{1 - PROBLEMA DE PESQUISA}

Circunscreveu-se a análise dos relatórios finais de acidentes da aviação geral no Brasil referentes a ocorrências no período compreendido entre 2005 e 2013, disponibilizados pelo Cenipa, procurando responder à seguinte pergunta: quais são os padrões dos acidentes da aviação geral, identificados por meio de inteligência artificial, que podem servir como base para políticas de prevenção e aumento da segurança de voo na categoria? 


\section{2 - HIPÓTESE}

Existem padrões nos acidentes da aviação geral possível de serem identificados nos relatórios finais de acidentes no Brasil, a partir dos quais se podem estabelecer medidas que contribuam para a prevenção de acidentes nessa categoria.

\section{3 - OBJETIVOS}

\subsection{1 - OBJETIVO GERAL}

Identificar padrões nos acidentes da aviação geral entre os anos de 2005 e 2013.

\subsection{2 - OBJETIVOS ESPECÍFICOS}

1. Identificar os principais padrões de ocorrência dos acidentes aéreos da aviação geral, especialmente àqueles ligados aos pilotos, com base nos relatórios finais emitidos pelo Cenipa

2. Avaliar utilização do método classificador de padrões Floresta de Caminhos Ótimos (OPF) em uma amostra pequena.

3. Analisar os dados obtidos nos relatórios finais do Cenipa visando identificar melhores práticas e oportunidades de melhoria.

\section{4 - JUSTIFICATIVA}

A relevância da presente pesquisa para a aviação brasileiras se dá pelo fato do país ser signatário da Organização Internacional da Aviação Civil (OACI), órgão que recomenda padrões de segurança visando ao desenvolvimento seguro e ordenado da aviação internacional. Isso torna o país responsável por evitar perdas humanas e materiais decorrentes de acidentes aeronáuticos (Brasil, 1971; 1982; 1986; 2014b; 2015b).

Além da obrigação em agir de acordo com o que preceituam os tratados celebrados, acidentes aéreos causam grande comoção social e muitas vezes chocam a população. Quando comparados com a aviação regular, os acidentes aéreos da aviação geral vitimam um número inferior de pessoas por acidente pelo fato de tratar-se de aeronaves menores, mas, em contrapartida, acidentes na aviação geral ocorrem com frequência muito superior à da aviação regular.

Alguns acidentes envolvendo a aviação geral no Brasil se tornaram especialmente conhecidos pela população brasileira em geral devido à repercussão gerada, especialmente pela fama das vítimas envolvidas, como por exemplo: o Bombardier Learjet em que se encontrava a banda Mamonas Assassinas, em 1996; o Embraer Legacy 600 norte-americano que se chocou com uma aeronave da aviação regular brasileira da "Gol Linhas Aéreas Inteligentes", derrubando o 
Boeing da linha aérea em uma densa área de floresta amazônica na Serra do Cachimbo, no Estado do Mato Grosso vitimando todos os tripulantes e passageiros, totalizando mais de 150 falecimentos no voo Gol 1907; o Cessna Citation 560XLS+ que se acidentou em um bairro residencial em Santos, SP, com o candidato a Presidente da República, Eduardo Campos; o EMB 820C Carajá que realizou pouso forçado próximo à Campo Grande, MS, com os apresentadores Angélica e Luciano Hulk e sua família em 2015, sem vítimas fatais; e o Cessna Citation VII, do banco Bradesco, que caiu próximo à divisa de Goiás com Minas Gerais em novembro de 2015, em que faleceram dois dos principais executivos do banco (além dos dois tripulantes).

O tema da segurança de voo na aviação geral tem sido discutido também no meio acadêmico. De acordo com Fangueiro (2008) quase $70 \%$ dos acidentes aeronáuticos ocorrem nessa categoria, que no Brasil tem aumentado a sua frota consideravelmente nos últimos anos (Abag, 2013a). Estatísticas apontam os fatores humanos e operacionais como os mais recorrentes em acidentes aeronáuticos (Marques, 2004; Martins et al., 2006) e a necessidade desses fatores serem mais profundamente estudados é defendida por vários autores, pois consideram que essa categoria de aviões está mais sujeita a acidentes pelo fato dos pilotos muitas vezes não receberem treinamento e capacitação suficientes para garantir a segurança aeronáutica (Araujo \& Bezerra, 2007; Fangueiro, 2008).

No entanto, não se encontrou análises sobre o padrão de ocorrência desses fatores e as relações entre todas as variáveis envolvidas em um acidente, especialmente pela complexidade e abrangência das informações contidas nos relatórios de acidentes, resultado da complexidade inerente ao sistema aeronáutico. Apesar disso, considera-se que o conhecimento desses padrões seja essencial para se identificar em quais linhas devem se concentrar os esforços ligados à prevenção de acidentes.

Buscou-se dar continuidade ao trabalho de Santi (2009) intitulado "Fatores Humanos Como Causas Contribuintes Para Acidentes e Incidentes Aeronáuticos na Aviação Geral" do curso de pós-graduação lato-sensu do Centro Interdisciplinar de Estudos em Transporte (Ceftru) da Universidade de Brasília (UnB), apresentado no ano de 2009. Nesse trabalho, o autor concluiu que "medidas educativas estão entre as mais recomendadas para evitar que novos acidentes ocorram pelos mesmos motivos" (Santi, 2009, p. 66). O autor ainda recomendou a promoção de palestras e seminários relacionados com segurança de voo visando aumentar o conhecimento que, na sua avaliação, é capaz de diminuir o risco de acidentes por fatores humanos. O mesmo autor afirma que situações adversas como falhas mecânicas e condições de tempo, por exemplo, não são tão preocupantes isoladamente. Santi (2009) ressalta, no entanto, que quando combinados com outros fatores, eles podem quebrar ou até mesmo remover as defesas do sistema, o que é extremamente preocupante. Por conta disso, o autor recomenda a revisão das leis e regulamentos que regem e regulam a atividade aérea no Brasil para adequá-los à realidade do momento e contribuir para o aumento da segurança de voo.

Outros autores consideram o treinamento como uma boa medida mitigadora de acidentes. Benson (1998) afirma que a prevenção a partir do treinamento tem sido uma constante na 
formação e manutenção operacional dos pilotos em todo mundo. Considera-se que, se o piloto é capaz de reconhecer fenômenos anormais (os fatores contribuintes) - conhecimento que pode ser adquirido por meio de treinamento ou vivência - a chance de adotar uma ação preventiva ou corretiva adequada a tempo é maior, evitando acidentes com perdas humanas e materiais (Benson, 1998; Gillingham \& Previc, 1996). A ação corretiva tomada a tempo se refere, nesse caso, tanto à altura em relação ao solo, quanto ao posicionamento e controle da aeronave em relação a seus eixos perpendiculares.

Por esses motivos, nesse trabalho objetivou-se identificar e analisar os padrões de nível de treinamento e experiência dos pilotos com características dos fatores contribuintes, das aeronaves e das fatalidades nos acidentes da aviação geral. Acredita-se que os resultados dessa dissertação possam auxiliar e motivar trabalhos semelhantes em outras modalidades de transporte (ferroviário, aquaviário e rodoviário), nas quais também ocorrem acidentes e, no caso dos transportes rodoviário e ferroviário, podem envolver pedestres e ciclistas que não são submetidos a qualquer treinamento formal antes de transitarem pelas vias.

A Universidade de Brasília - UnB, por sua localização estratégica na capital do país, pode vir a exercer papel fundamental em parcerias ligadas a órgãos como o Cenipa e a Agência Nacional de Aviação Civil (Anac). Essas parcerias podem levar, por exemplo, ao estabelecimento e criação de novas leis e exigências no auxílio e suporte ao desenvolvimento de treinamento e capacitação a pilotos do país - estendendo-se a outros agentes envolvidos com a segurança de voo ou de transportes de uma maneira geral - por meio do Centro de Formação de Recursos Humanos em Transportes (Ceftru).

As informações e análises sobre a ocorrência de fatores contribuintes contidas nesse trabalho podem servir de subsídio para a alteração e aperfeiçoamento da legislação e das exigências existentes quanto à capacitação dos pilotos, bem como na elaboração de novas diretrizes que possam contribuir para aprimorar a segurança de voo da aviação geral, conforme recomendado por Santi (2009).

\section{5 - REVISÃO BIBLIOGRÁFICA}

Antes da busca externa por bibliografia, procurou-se o que existia de material sobre aviação civil e acidentes na Universidade de Brasília, especialmente no acervo do Programa de PósGraduação em Transportes (PPGT) e na biblioteca do Centro Interdisciplinar de Estudos em Transportes (Ceftru), onde foram ministrados diversos cursos de especialização relacionados ao transporte aéreo.

No acervo do PPGT, não foi encontrado material relevante à área de segurança de voo, fatores humanos ou treinamento na aviação civil. No entanto, deve-se ressaltar a dificuldade na busca por meio de páginas eletrônicas e a limitação existente pela procura se dar por meio de uma busca sem auxílio de nenhuma ferramenta de banco de dados, apenas procurando na biblioteca física do programa. 
No acervo do Ceftru há materiais ligados tanto ao treinamento de pilotos, quanto a segurança de voo, os quais foram utilizados nesse trabalho, com destaque para Araújo \& Bezerra (2007) e Santi (2009).

Também foram levantados materiais por meio da utilização de motores de busca disponíveis na base de dados da Coordenação de Aperfeiçoamento de Pessoal de Nível Superior (CAPES), principalmente nas bases Scopus, Science Direct, Web of Science e Elsevier. Foi utilizada também a rede social Research Gate, principalmente para realizar pedidos de artigos diretamente a alguns autores. Nesses motores de busca, procurou-se pelos termos combinados com algoritmos booleanos ${ }^{1}$, inicialmente em português, conforme o quadro 1.1 , e posteriormente em inglês, o que permitiu encontrar um número maior de trabalhos:

Quadro 1.1 - Termos combinados com algoritmos booleanos (elaborado pelo autor).

\begin{tabular}{|c|}
\hline "Aviação" E "Fatores Contribuintes" \\
\hline "Fator* Human*” E “Aviação” \\
\hline "Fator* Human*” E "Acident*” \\
\hline "Aviação Civil” E "Segurança de Voo" \\
\hline “Aviação Geral” E “Acident*” \\
\hline "Aviação Geral” E “Acident*” E "Fator* Human*” \\
\hline "Aviação" E “Queijo Suiço" \\
\hline “Aviação" E “Reason" \\
\hline "Aviação" E “SHELL” \\
\hline "Aviação" E "HFACS” \\
\hline "Floresta de Caminhos Ótimos" E "OPF" \\
\hline "Clusterização" E "Aprendizado de Máquina" \\
\hline
\end{tabular}

\footnotetext{
${ }^{1}$ Palavras que definem para o motor de busca de que forma deve ser feita a combinação entre os termos ou expressões em uma pesquisa.
} 


\section{6 - ESTRUTURA DA DISSERTAÇÃO}
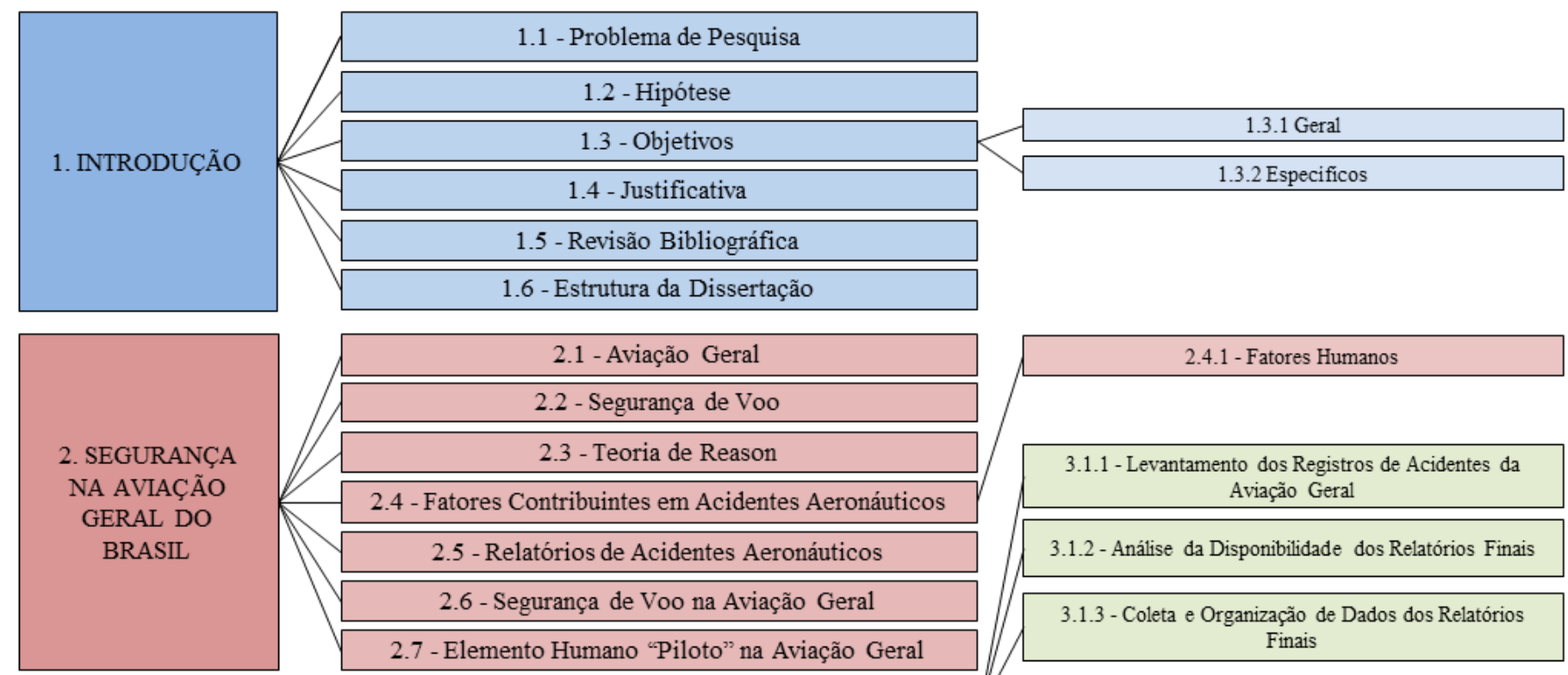
3.1.1 - Levantamento dos Registros de Acidentes da Aviação Geral

3.1.2 - Análise da Disponibilidade dos Relatórios Finais

2.7 - Elemento Humano "Piloto" na Aviação Geral

3. FERRAMENTAS,
PROCEDIMENTOS
E MÉTODOS

3.1 -Coleta e organização de Dados de Acidentes

3.1 .3 - Coleta e Organização de Dados dos Relatórios Finais
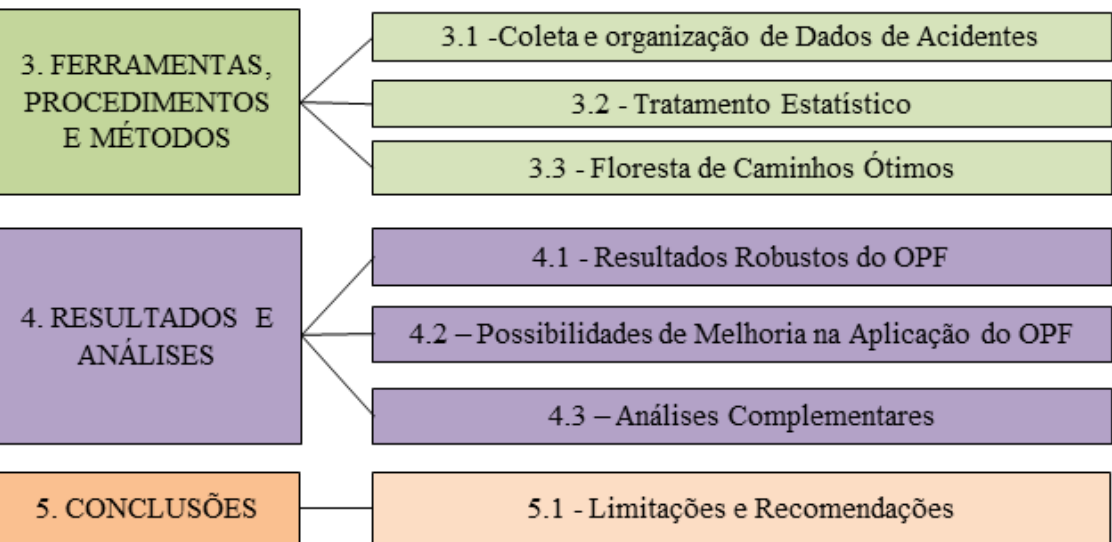

5.1 - Limitações e Recomendações

\begin{tabular}{|c|}
\hline Finais \\
\hline 4.1 .1 - Experiència \\
\hline 4.1 .2 - Qualificação \\
\hline 4.1 .3 - Fatores \\
\hline 4.1 .4 - Quantidade de Motores \\
\hline 4.2 .1 - Experiência \\
\hline 4.2 .2 - Fatores Indeterminados \\
\hline 4.2 .3 - Motorização \\
\hline 4.2 .4 - Copiloto \\
\hline
\end{tabular}

Figura 1.1 - Estrutura da Dissertação (elaborada pelo autor) 


\section{2 - SEGURANÇA DE VOO NA AVIAÇÃO GERAL NO BRASIL}

Esse capítulo se divide em: caracterização do que é tratado no presente trabalho como Aviação Geral; apresentação do tema da Segurança de Voo; embasamento na Teoria de Reason; descrição do que são os Fatores Contribuintes em Acidentes Aeronáuticos; breve explicação sobre o que são e para que servem os Relatórios de Acidentes Aeronáuticos utilizados como base de dados desse trabalho; caracterização da Segurança de Voo na Aviação Geral; e por fim, numa análise do Elemento Humano "Piloto" na Aviação Geral.

\section{1 - AVIAÇÃO GERAL}

Por mais que algumas pessoas externas ao meio aeronáutico confundam, o termo "aviação geral" não é sinônimo de "aviação em geral". De modo a esclarecer tal diferença, é necessário explicar quais são as categorias da aviação, destacando o que é considerado como aviação geral.

A classificação das aeronaves brasileiras começa por uma divisão entre aeronaves públicas e privadas. Como a aviação geral é composta apenas por aeronaves privadas, demonstram-se e explicam-se as categorias de registro de aeronaves privadas e as suas siglas, de acordo com a Anac (2003, 2013).

- Administração Indireta Federal (AIF) - A serviço das autarquias, empresas públicas, sociedades de economia mista e fundações da administração indireta federal, para transporte não remunerado de autoridades, pessoas ou materiais.

- Administração Indireta Estadual (AIE) - A serviço das autarquias, empresas públicas, sociedades de economia mista e fundações da administração indireta estadual, para transporte não remunerado de autoridades, pessoas ou materiais.

- Administração Indireta Municipal (AIM) - A serviço das autarquias, empresas públicas, sociedades de economia mista e fundações da administração indireta municipal, para transporte não remunerado de autoridades, pessoas ou materiais.

- Administração Indireta do Distrito Federal (AID) - A serviço das autarquias, empresas públicas, sociedades de economia mista e fundações da administração indireta do Distrito Federal, para transporte não remunerado de autoridades, pessoas ou materiais.

- Serviço de Transporte Público Não-Regular - Táxi Aéreo (TPX) - Serviços de transporte aéreo público não regular de passageiro ou carga, realizados por pessoa natural ou jurídica brasileira, autorizada, mediante remuneração convencionada entre o usuário e o transportador, visando proporcionar atendimento imediato, independente de horário, percurso ou escala. 
- Serviço Aéreo Especializado Público (SAE) - Prestação de serviço aéreo especializado, realizado por pessoa física ou jurídica brasileira, autorizada, mediante remuneração, envolvendo somente as pessoas e materiais relacionados com a execução do serviço. Exemplos de SAE são: aerofotografia, aerofotogrametria, aerocinematografia, aerotopografia; prospecção, exploração ou detecção de elementos do solo ou do subsolo, do mar, da plataforma submarina, da superfície das águas ou de suas profundezas; publicidade aérea de qualquer natureza; fomento ou proteção da agricultura em geral; saneamento, investigação ou experimentação técnica ou científica; provocação artificial de chuvas ou modificação de clima; qualquer outra modalidade de serviço remunerado, distinto do transporte público de pessoas, cargas e malas postais.

- Serviço de Transporte Aéreo Público Regular Doméstico ou Internacional (TPR) Serviços de transporte aéreo público, realizado por pessoas jurídicas brasileiras, por concessão e mediante remuneração em troca do transporte de passageiro, carga ou mala postal, no âmbito regional, nacional ou internacional.

- Serviço de Transporte Aéreo Público Não-Regular, Doméstico ou Internacional (TPN) Serviços de transporte aéreo público não regular de passageiro, carga ou mala postal, realizados por pessoa física ou jurídica brasileira, autorizadas, mediante remuneração, entre pontos situados no país, entre um ponto situado no território nacional e outro em país estrangeiro ou entre pontos situados em países estrangeiros.

- Instrução (PRI) - Uso na instrução, treinamento e adestramento de voo pelos aeroclubes, clubes ou escolas de aviação civil proprietárias da aeronave, podendo ser usada, ainda, para prestar tais serviços a pessoal de outras organizações sob contrato aprovado pelo DAC e como aeronave administrativa da entidade sua proprietária. Essas aeronaves não podem ser utilizadas na prestação de qualquer serviço aéreo público, remunerado ou não.

- Experimental (PET) - Essa categoria de aeronaves é dividida em três tipos de utilização:

- Por fabricantes ou centros de pesquisa e de desenvolvimento aeronáutico privados ou da administração pública indireta com as seguintes finalidades: obtenção de certificado de homologação de tipo, certificado suplementar de homologação de tipo e emendas a tais certificados, ensaios em voo de novas concepções de projetos de aeronaves, novos equipamentos aeronáuticos, novas técnicas operacionais, novas instalações em aeronaves e novos empregos para aeronaves.

- Operação restrita de protótipo após a conclusão ou cancelamento do respectivo processo de homologação de tipo, não podendo efetuar nenhum serviço aéreo remunerado.

○ Operação restrita de aeronaves produzidas por amadores e de outras aeronaves não homologadas, como aquelas destinadas exclusivamente ao desporto e lazer, não podendo efetuar nenhum serviço aéreo remunerado. 
- Privada - Histórica (PRH) - Aeronave a serviço de museus e entidades afins, inclusive dos órgãos da administração indireta Federal, Estadual, Municipal ou do Distrito Federal, utilizadas em amostras e voos de exibição, restritas a essas finalidades e declaradas como tal na forma da legislação em vigor.

- Serviços Aéreos Privados (TPP) - Essa é a categoria considerada como aviação geral nesse trabalho. Trata-se de serviços de transporte realizados sem remuneração, em benefício dos proprietários ou operadores, compreendendo as atividades aéreas de recreio ou desportivas, de transporte reservado ao proprietário ou operador, de serviços aéreos especializados realizados em benefício exclusivo do proprietário ou operador, não podendo efetuar quaisquer serviços aéreos remunerados para terceiros.

Considerando os seus aviões, que são utilizados tanto para o transporte quanto para o lazer, essa categoria engloba desde modelos conhecidos por "jatos" e turboélices, até aviões convencionais (movidos pelo conjunto pistão-hélice) (Abag, 2013a).

Os “jatos”, como são conhecidos, são, na verdade, aeronaves de asa fixa, cuja função primária é transportar passageiros, equipados com motores à reação, movidos por querosene de aviação JET A-1, com uma turbina acoplada a um "fan" (espécie de ventoinha). Esses aviões são especialmente projetados para grandes velocidades de cruzeiro, com melhor desempenho em altitudes elevadas. Um exemplo de "jato" da aviação geral encontra-se na Fig. 2.1.

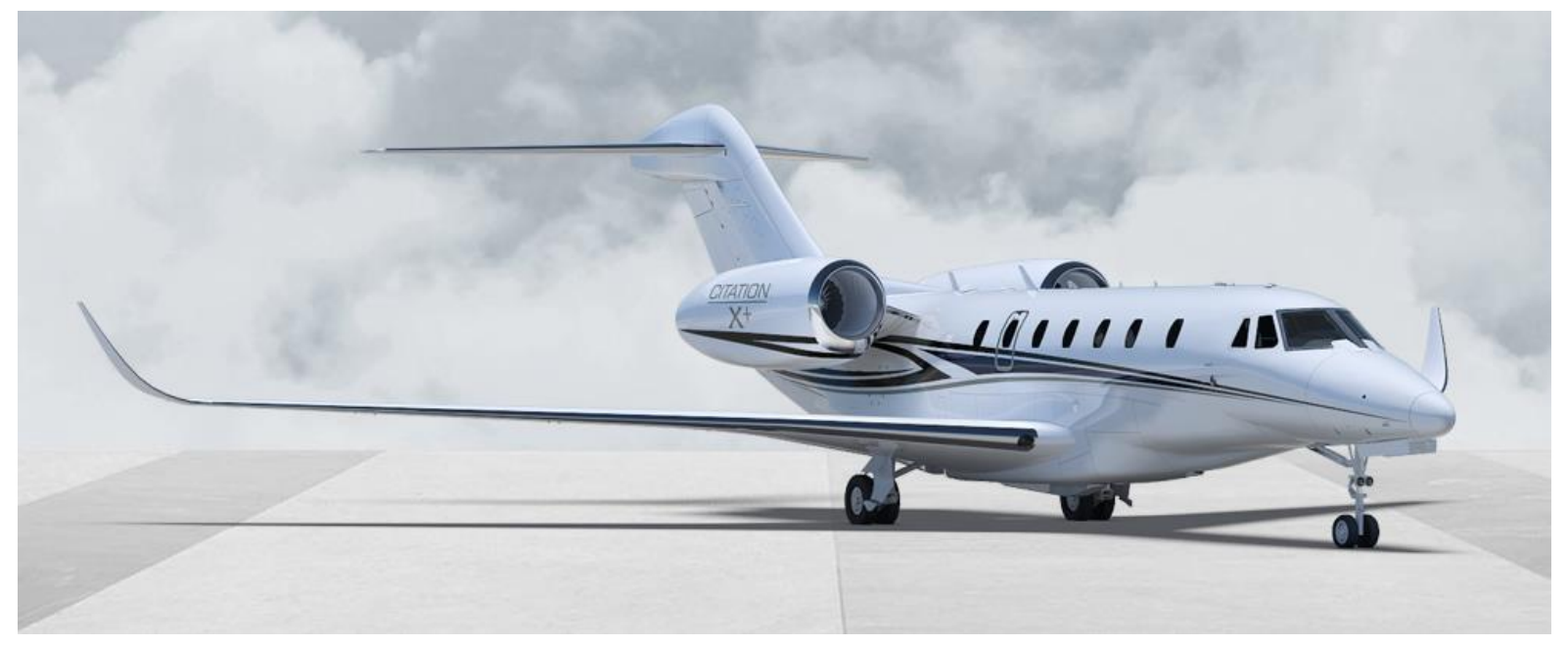

Figura 2.1 - Cessna Citation X (Cessna, 2015).

Os turboélices possuem um motor de reação mista pelo fato de, basicamente, possuírem um motor a jato que aciona uma hélice (ao invés de uma ventoinha, como é o caso dos jatos). Esses aviões também são movidos a querosene de aviação JET A-1, e operam em altitudes intermediárias entre os jatos e os aviões convencionais (movidos pelo conjunto pistão-hélice). Um exemplo de turboélice na aviação geral encontra-se na Fig. 2.2. 


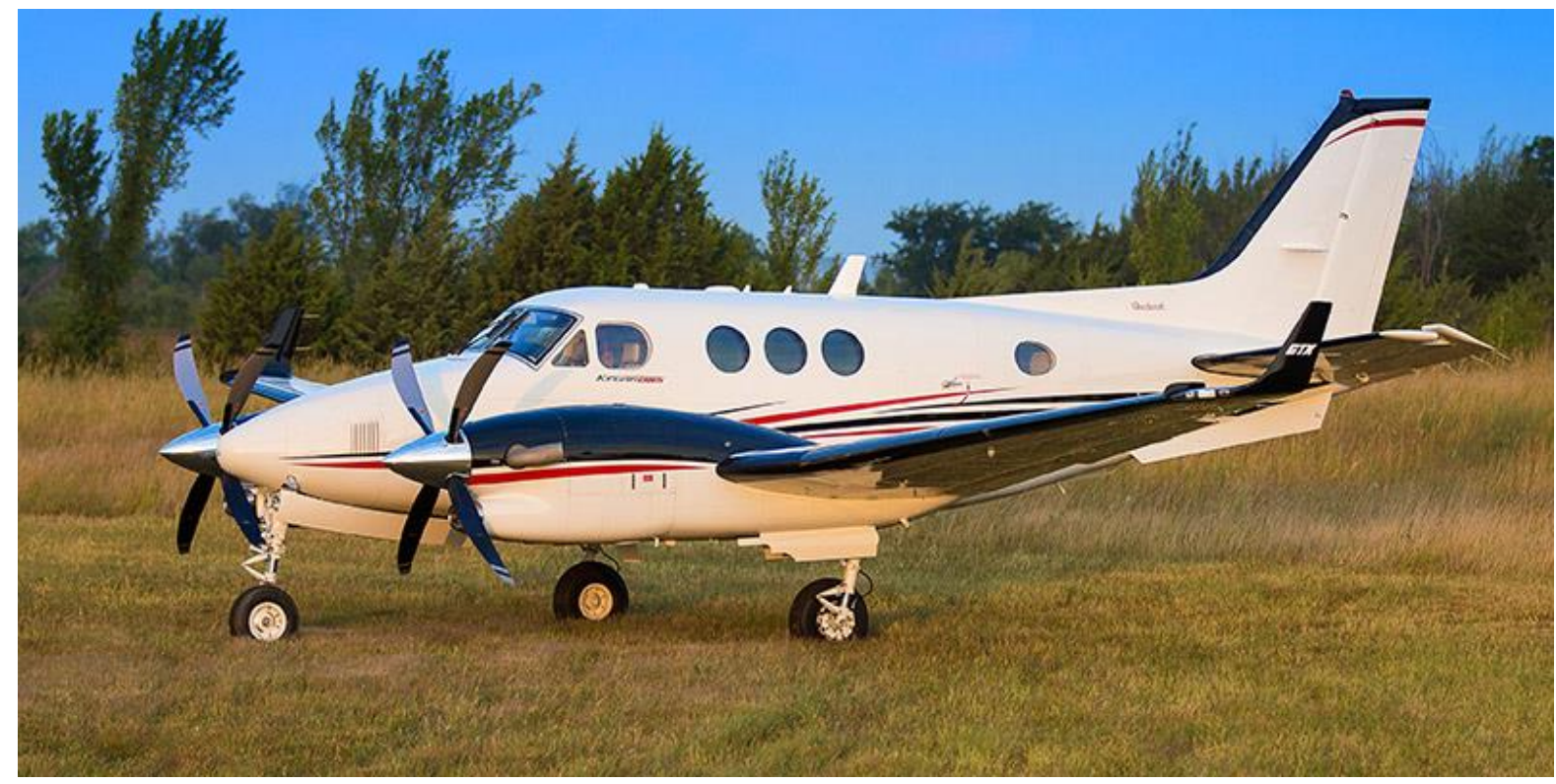

Figura 2.2 - Beechcraft King Air C90 GTX (Beechcraft, 2015).

Os aviões conhecidos como "convencionais", são movidos pelo conjunto pistão-hélice, ou seja, um motor de combustão interna, movido à gasolina de aviação AVGAS, que faz girar uma hélice. Para efeito de comparação, esse motor se assemelha ao de um carro à gasolina, mas ao invés de fazer girar um eixo de rodas, faz girar a hélice, conforme o exemplo da Fig. 2.3 .

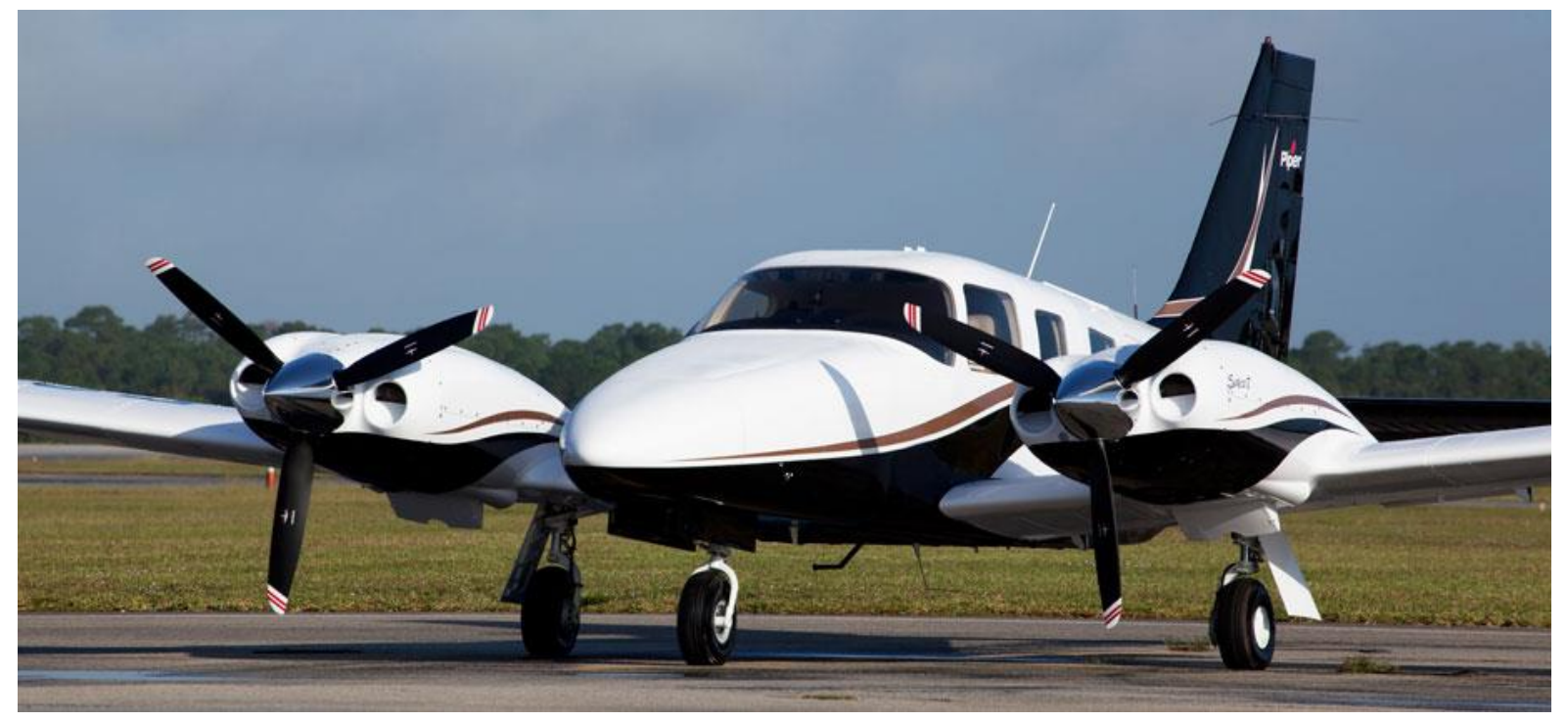

Figura 2.3 - Piper Seneca V (Piper, 2015).

Essa categoria (aviação geral) possui características técnicas, operacionais e regulatórias próprias às suas atividades, podendo ser considerada equivalente ao transporte rodoviário motorizado individual (o carro, por exemplo). A Associação Brasileira de Aviação Geral (Abag) elabora um documento anual com informações sobre o setor da aviação geral, nos 
moldes do documento elaborado pela Anac para a aviação regular. O Anuário Brasileiro de Aviação Geral reúne dados atualizados sobre diversos itens do setor, como por exemplo, a segmentação da frota nacional por idade, tipo, uso e quantidade por estado da federação, bem como a movimentação da aviação geral nos maiores aeroportos do país (Abag, 2013a). Nesse documento, a aviação geral é tratada em conjunto com outras categorias que não condizem com o transporte de passageiros, sendo subdividida em: Serviço Aéreo Privado (SAP); Taxi Aéreo; Instrução; Agrícola; e outros. O foco do presente trabalho é no transporte privado de passageiros, portanto, no que é considerado como SAP.

A frota de aeronaves convencionais, de 2011 para 2014, passou de 9.770 para 10.994 composta por 8.522 aviões monomotores e 2.372 bimotores (Abag, 2015), sendo a aviação geral (Serviço Aéreo Privado) a maior frota atual de aeronaves da aviação geral do Brasil, conforme apresentado na Fig. 2.4.

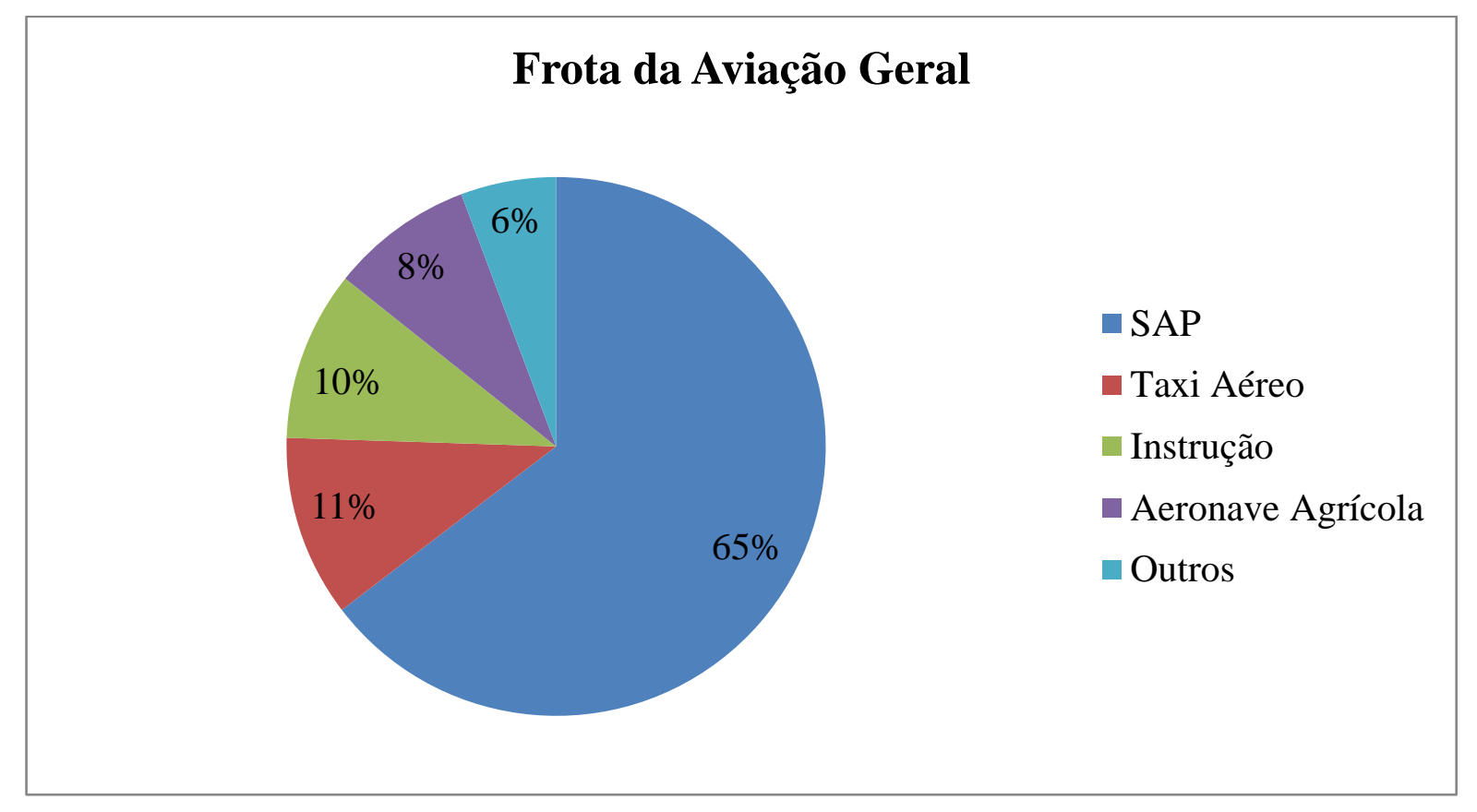

Figura 2.4 - Composição da frota da Aviação Geral (modificada - Abag, 2015).

A Fig. 2.4 condiz com o que afirma Fangueiro (2008) ao demonstrar que, entre 1997 e 2007, $67 \%$ dos acidentes da aviação geral ocorreram com aeronaves pistão-hélice (convencionais) e turboélice.

É possível, portanto, notar que os serviços aéreos privados são a categoria que mais possui aeronaves dentro do que a Abag considera por aviação geral, representando $65 \%$ do total, devido a uma frota de 9.770 aeronaves. 


\section{2 - SEGURANÇA DE VOO}

O Brasil é signatário da Organização Internacional da Aviação Civil (OACI), agência especializada da Organização das Nações Unidas (ONU), que foi criada no final da Segunda Guerra Mundial. A OACI regulamenta, organiza, estabelece princípios e desenvolve técnicas com o intuito de propiciar o progresso da aviação civil internacional com segurança, eficiência e economia (Brasil, 1946). Essa organização define segurança operacional como "estado no qual o risco de lesões às pessoas ou danos aos bens se reduzem e se mantém em um nível aceitável, por meio de um processo contínuo de gerenciamento de riscos" (OACI, 2013, p.17, tradução livre²).

Por recomendação da OACI (2003), o Brasil desenvolveu o Sistema de Investigação e Prevenção de Acidentes Aeronáuticos (Sipaer) que tem a finalidade de planejar, orientar, coordenar, controlar e executar as atividades de investigação e prevenção de acidentes aeronáuticos (Brasil, 1971; Brasil, 1982). O Sipaer tem como órgão central, desde 1971, uma organização militar denominada Cenipa.

O Cenipa faz parte do Comando da Aeronáutica (Força Aérea Brasileira) e está subordinado ao Ministério da Defesa. O órgão é responsável pela organização das atividades necessárias ao funcionamento e ao desenvolvimento do Sipaer, visando evitar perdas de vida e de material decorrentes de acidentes aeronáuticos (Brasil, 1971; Brasil, 1982; Brasil, 2014b). Mesmo com a criação da Agência Nacional de Aviação Civil (Anac) em 2005, o Sipaer continuou sob a responsabilidade do Cenipa (Brasil, 2005; Madeira, 2008).

O Cenipa publica, periodicamente, um panorama estatístico de todas as categorias da aviação civil brasileira baseado nos relatórios de investigação de acidentes, denominado Folheto do Comando da Aeronáutica (FCA). Esse documento serve de complemento às orientações do órgão para a Aviação Civil Brasileira, no âmbito das competências de prevenção de acidentes aeronáuticos do Sipaer. O objetivo desse documento é permitir que, por meio dos dados nele expostos, a comunidade aeronáutica concentre seus esforços na prevenção de acidentes nas áreas mais críticas (Brasil, 2013).

A aviação geral é composta por $73 \%$ de aviões convencionais, com idade média de 31 anos (Abag, 2015). Isso pode significar que a maior parte da frota da aviação geral fica mais sujeita a falhas e panes, mesmo com manutenção adequada. A Fig. 2.5 apresenta a composição da frota de aeronaves convencionais no país no ano de 2012, com $60 \%$ de aeronaves com mais de 30 anos.

\footnotetext{
2 "the state in which the possibility of harm to persons or of property damage is reduced to, and maintained at or below, an acceptable level through a continuing process of hazard identification and safety risk management"
} 


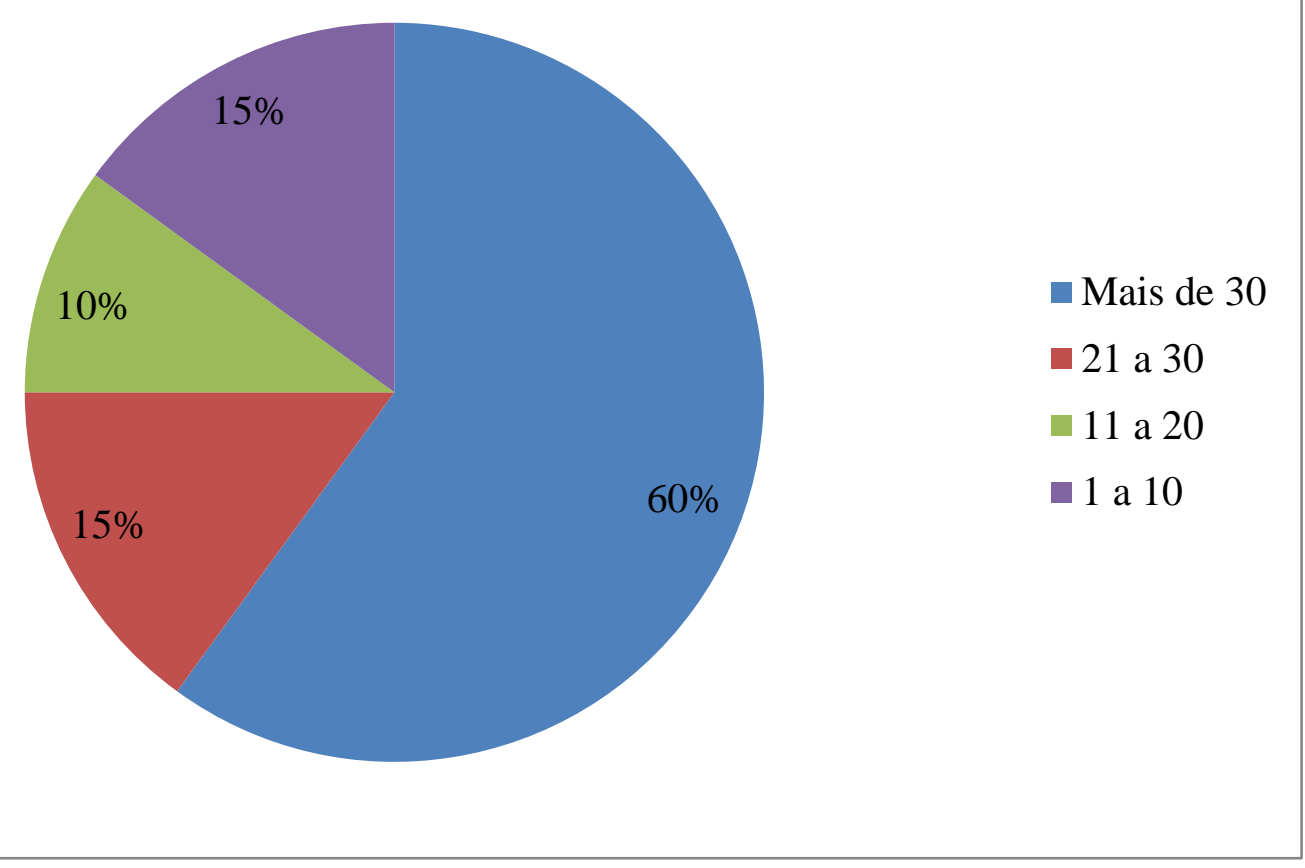

Figura 2.5 - Idade da frota de aviões à pistão em 2012 (em anos) (modificada - Abag, 2013a).

Tratando-se de acidentes e incidentes aeronáuticos, a OACI recomenda para a comunidade científica de países signatários a utilização da Teoria de Reason, no que diz respeito aos acidentes (Barreto, 2008).

\section{3 - TEORIA DE REASON}

A teoria para a ocorrência de acidentes apresentada por James Reason em 1990 é conhecida por teoria do "queijo suíço". Essa teoria defende que um acidente acontece devido a vários fatores contribuintes combinados, não derivando de causas isoladas (Reason, 1990). A teoria de Reason é amplamente difundida e aceita pela indústria e pelos órgãos reguladores da aviação, pois permite uma boa compreensão do erro humano de uma maneira sistêmica - de acordo com o conceito de sistêmico abordado em Cunha (1997) - sendo muito utilizada na investigação de acidentes aeronáuticos.

A teoria do "queijo suíço" se fundamenta na influência de sistemas complexos ${ }^{3}$ (Axelrod \& Cohen, 2001; Grabowski \& Strzalka, 2008) sobre o indivíduo, como é o caso da aviação. Reason (1992) explica que esses sistemas são constituídos de camadas de defesa em profundidade, que garantem a segurança e são ameaçadas por falhas latentes e ativas. Esse modelo é exemplificado na Fig. 2.6.

\footnotetext{
3 “Agentes, de uma variedade de tipos, usam suas estratégias, em interações padronizadas, uns com os outros e com artefatos. Medidas de desempenho sobre os eventos resultantes impulsionam a seleção de agentes ou estratégias através de processo de cópia e recombinação, mudando assim as frequências dos tipos dentro do sistema" (Axelrod \& Cohen, 2001, grifo nosso, tradução livre).
} 


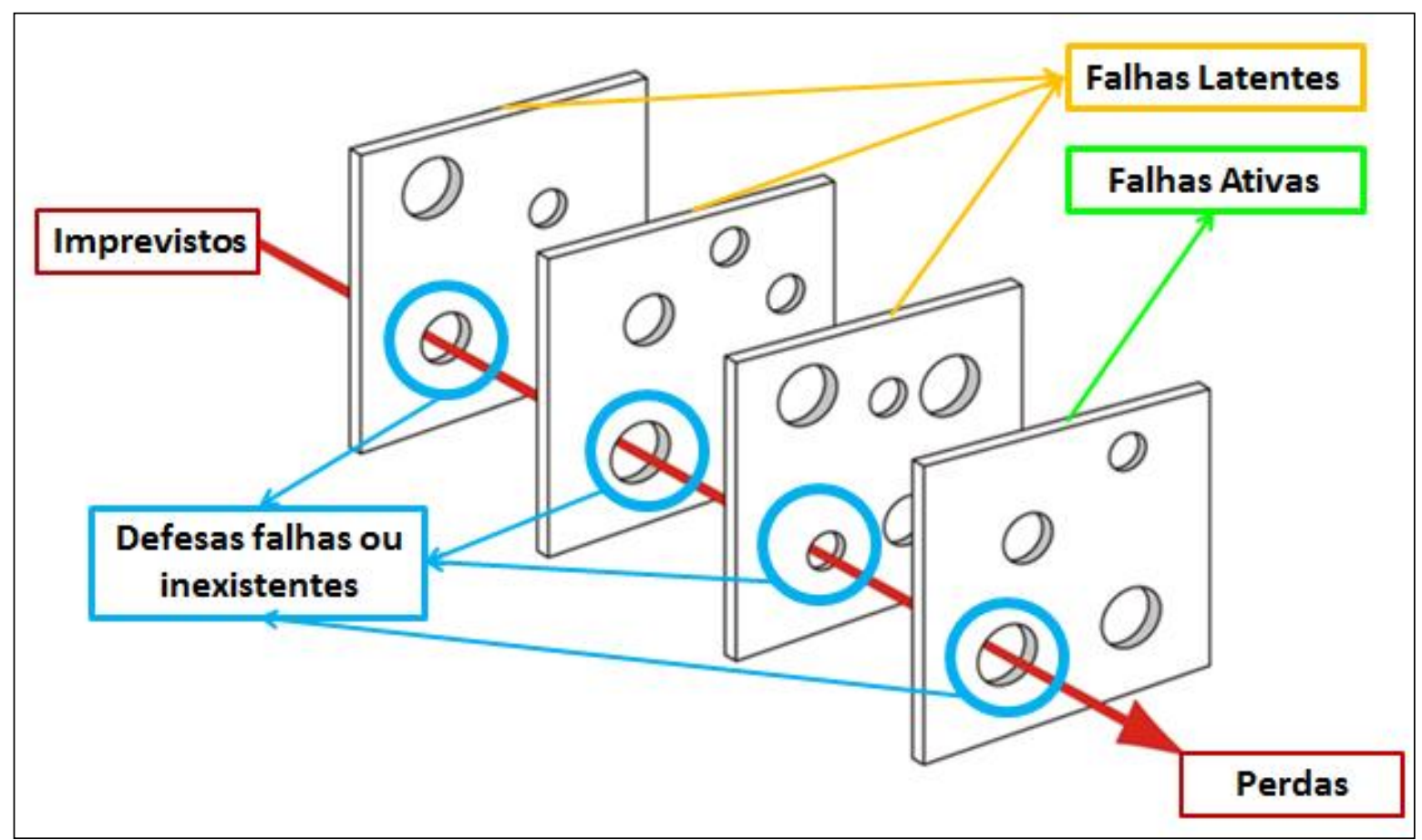

Figura 2.6 - Esquema da Teoria do Queijo Suíço (modificada - Reason, 1992).

As falhas latentes são resultados de decisões tomadas em níveis mais elevados do sistema e que permanecem dormentes até que seus efeitos sejam ativados por circunstâncias operacionais, conhecidas por falhas ativas - que seriam falhas de equipamento ou erros operacionais. Na teoria de Reason, as falhas ativas não são, portanto, a causa das rupturas nessas camadas de defesa, mas apenas o estopim sobre falhas latentes (Reason, 1995). Pereira \& Ribeiro (2001) exemplificam como erros latentes, inclusive, as políticas que determinam a despreocupação com o treinamento em um sistema ligado à aviação.

Reason (2005) defende que antes de considerar os operadores como principais causadores do acidente, faz-se necessário compreendê-los como herdeiros de defeitos do sistema. Para o mesmo autor, esses defeitos de sistema podem ser criados, por exemplo, por uma concepção mal feita, uma instalação inadequada, manutenção deficiente ou por decisões errôneas da direção (Reason, 2002).

\section{4 - FATORES CONTRIBUINTES EM ACIDENTES AERONÁUTICOS}

Leveson (2002) recomenda que seja adotada na investigação de acidentes, de uma maneira geral, e não apenas na aviação, uma visão ampla do ocorrido, não se restringindo apenas aos eventos próximos. $\mathrm{O}$ autor ainda ressalta a necessidade de se explorar e gerir tanto as deficiências estruturais, quanto as falhas na cultura de segurança, do sistema ou da sociedade.

De acordo com o Cenipa (Brasil, 2013), os fatores contribuintes para acidentes aeronáuticos são divididos quanto à "Área" e subdivididos quanto ao "Aspecto" do fator. Quanto à "Área", o órgão divide os fatores contribuintes em "Materiais" e "Humanos". Já quanto ao "Aspecto" 
do fator contribuinte, o órgão militar não subdivide a "Área" de "Fatores Materiais", mas subdivide os "Fatores Humanos" em "Fatores Humanos Médicos", "Fatores Humanos Psicológicos" e "Fatores Humanos Operacionais", enquanto que Martins et al. (2006) não subdividem os Fatores Humanos pelos seus aspectos, tratando Fatores "Psicológicos", "Operacionais" e "Médicos" de forma conjunta.

O Cenipa explica que Fator Material é a área de abordagem da segurança de voo que se refere à aeronave no seu projeto, fabricação e de manuseio de material (Brasil, 2013). Esses fatores não incluem os serviços de manutenção de aeronave, que são realizados por humanos e estão, portanto, sujeitos a falhas psicológicas, médicas ou operacionais.

No entanto, ao separar Fator Humano de Fator Operacional, o Cenipa acaba por tornar confusa essa caracterização. O órgão define que Fator Humano é a área de abordagem da segurança de voo que se refere ao complexo biológico do ser humano, em sua fisiologia (médica) e psicológicos que podem refletir nas ações da tripulação e demais pessoas envolvidas no acidente. A confusão se torna possível por separar de Fator Humano, os Fatores Operacionais, que são resultados de ações humanas. Ainda assim, o Cenipa define que Fator Operacional é a área de abordagem da segurança de voo que se refere ao desempenho do ser humano na atividade relacionada com o voo (Brasil, 2015a).

Organizaram-se os fatores contribuintes quanto ao seu aspecto conforme o mapa mental da Fig. 2.7.

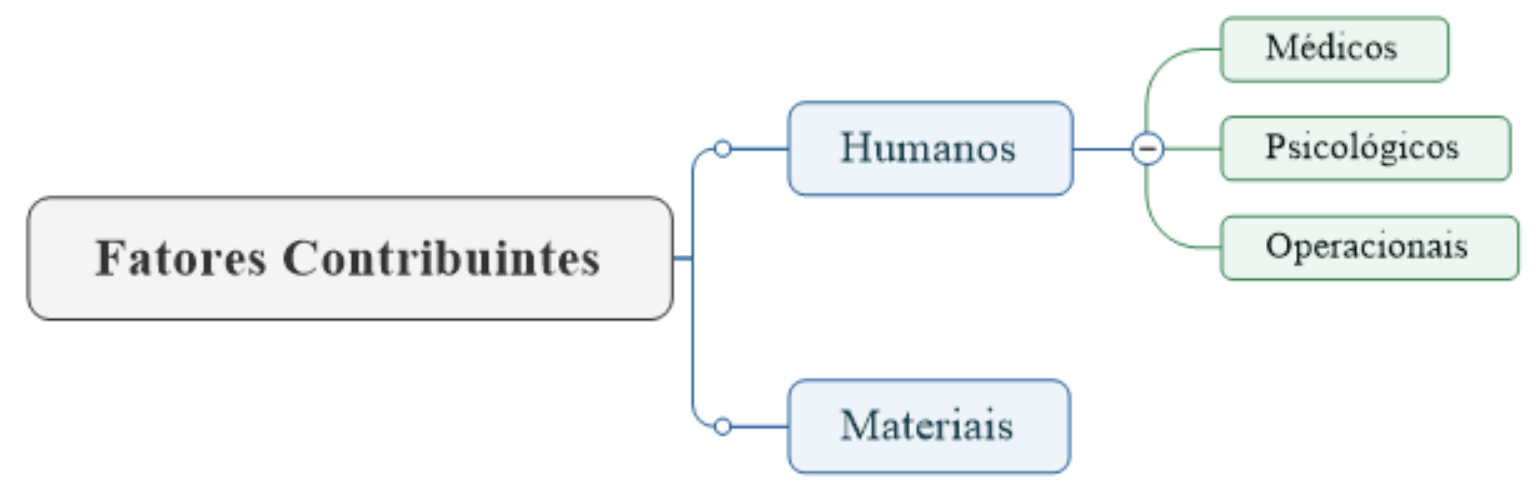

Figura 2.7 - Mapa mental dos aspectos dos fatores contribuintes (elaborada pelo autor)

A seguir, são explicados alguns aspectos dos fatores (Brasil, 2013) sendo que os fatores específicos de cada aspecto podem ser encontrados no Anexo A.

- Fatores Materiais - Podem estar ligados tanto à aeronave quanto ao complexo de engenharia aeronáutica, abrangendo aspectos relacionados à fabricação, ao manuseio de materiais, ao projeto da aeronave ou de algum componente, e a equipamentos de solo, como radar, por exemplo.

- Fatores Humanos Médicos - Abrangem o homem sob o ponto de vista biológico em seus aspectos fisiológicos, como a utilização de álcool ou outras drogas, ansiedade, desorientação espacial, dieta inadequada, algum tipo de dor ou enfermidade, enjoo 
aéreo, fadiga, gravidez, inconsciência, insônia, intoxicações, efeitos de algum medicamento e obesidade, por exemplo.

- Fatores Humanos Psicológicos - Levam em conta características psicológicas, organizacionais e sociais dos recursos humanos envolvidos no acidente. São fatores como atitude, estado emocional, motivação, indícios de estresse, dinâmica de equipe, cultura do grupo de trabalho, e cultura organizacional, por exemplo.

- Fatores Humanos Operacionais - Alcançam todas as circunstâncias da operação, manutenção da aeronave e infraestrutura aeronáutica, incluindo o controle do espaço aéreo. Alguns exemplos desses fatores podem ser a aplicação de comandos, indisciplina de voo, julgamento de pilotagem, manutenção de aeronave, planejamento de voo, pouca experiência do piloto, e desconhecimento de normas de sistema de tráfego aéreo.

A ocorrência dos fatores contribuintes nos Relatórios de Acidentes é classificada como "não contribuiu", "contribuiu" ou "indeterminado", sendo que são considerados para as estatísticas do Cenipa apenas os fatores constatados como "contribuiu". No entanto, foram considerados também, nesse trabalho os fatores "indeterminado", levando em consideração o fator classificado como indeterminado ter sido levantado como possível de estar presente pelo órgão investigador, e para fins de prevenção pode, portanto, ser relevante, o que justifica a sua inclusão no presente estudo.

\subsection{1 - FATORES HUMANOS}

A participação de fatores humanos em acidentes ligados a sistemas complexos, como é o caso de acidentes aeronáuticos (Shappell et al., 2007), tem sido crescente nas últimas décadas (Dekker, 2002; Woods \& Hollnagel, 2006). É o exemplo do fator "Julgamento" (Anexo A), que significa que o piloto poderia ter evitado o acidente caso tivesse tomado a decisão adequada. Esse fator aparece em 48,4\% de acidentes tipo "falha de motor em voo" no país (Brasil, 2013).

Os estudos na área de fatores humanos foram intensificados durante a Segunda Guerra Mundial pela incompatibilidade entre o projeto das máquinas e equipamentos bélicos e as características físicas e psicofisiológicas do ser humano (Vidal, 1999). Barreto (2008) explica que, nessa fase, as pesquisas se concentraram na interação entre o ser humano, a máquina e o ambiente físico. Após diversas mudanças realizadas a partir da década de 1970, o erro humano deixou de ser visto como causa dos acidentes e passou a ser considerado como consequência de fatores sistêmicos, algumas vezes até distantes da operação - e não das limitações humanas - justificando a sua pesquisa (Vidal, 1999; Barreto, 2008). A simples associação do erro humano ao desempenho deficiente dos operadores na ponta de linha é, portanto, um equívoco (Helmreich, 1998; Martins et al., 2006; Barreto, 2008). 
Apesar de ser necessário considerar a complexidade envolvida em fatores humanos, o trabalho procurou analisar, sobretudo os fatores de dificuldade, que são os inerentes ao trabalho executado pelo operador a partir de suas habilidades, competências e saberes, conforme definido por Amalberti (1996). É importante que essa definição esteja muito clara para que não seja confundida com fatores de complexidade, os quais são os externos ao operador (Perrow, 1984).

Para se compreender a dinâmica envolvida nos fatores humanos que foram foco das análises dos relatórios do Cenipa e a possível relação dos mesmos com os pilotos, procurou-se estudar, antes de iniciar as análises, o Human Factors Analysis and Classification System, conhecido também como Modelo HFACS. O HFACS é um modelo utilizado para investigar e analisar as causas de acidentes aeronáuticos decorrentes especificamente de fatores humanos (Wiegmann \& Shappell, 1997). Esse modelo foi desenvolvido em razão da dificuldade encontrada em se analisar e investigar dados armazenados em diferentes sistemas de registro de acidentes aeronáuticos.

O modelo organiza os fatores de risco em quatro níveis de falhas, apresentadas em ordem crescente sendo elas: influências organizacionais; supervisão insegura; pré-condições para ações inseguras; e ações inseguras (Wiegmann \& Shappell, 2001; DOD HFACS, 2005). Buscando compreender o papel do piloto nessa visão sistêmica, analisam-se a sua ligação com os quatro níveis considerados pelo modelo HFACS (Wiegmann \& Shappell, 2003) explicitados nas Figs. 2.8, 2.9, 2.10 e 2.11.

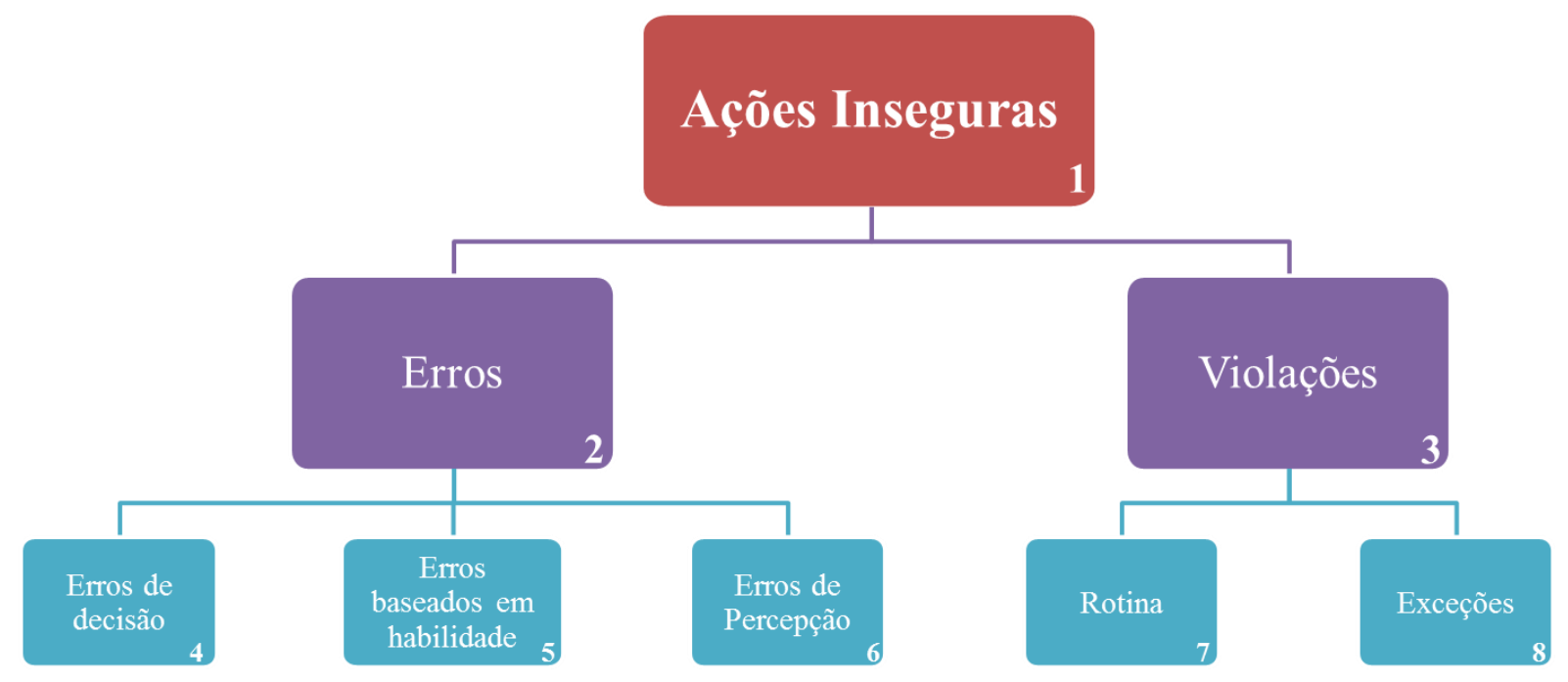

Figura 2.8 - Primeiro nível do método HFACS (tradução livre, modificada - Wiegmann \& Shappell, 1997).

No primeiro nível, das ações inseguras (1), já se encontram itens que podem ser ligados aos pilotos, especialmente em relação ao treinamento e experiência, tanto na área de erros (2) quanto na área de violações (3). Os erros de decisão (4) têm relação direta com o conhecimento do piloto, partindo-se do pressuposto de que alguém ciente dos procedimentos, 
riscos e situações pode decidir melhor; os erros de habilidade (5) são consequência da falta de treino prático, enquanto que os erros de percepção (6) indicam a falta de conhecimento teórico para reconhecer situações. As violações também podem ser minimizadas por meio de treinamento, pois a partir do momento em que se tem consciência dos riscos decorrentes dos erros ligados à rotina operacional (7) e os erros que podem advir de exceções (8) aos padrões de segurança, a ocorrência desses itens pode ser diminuída.

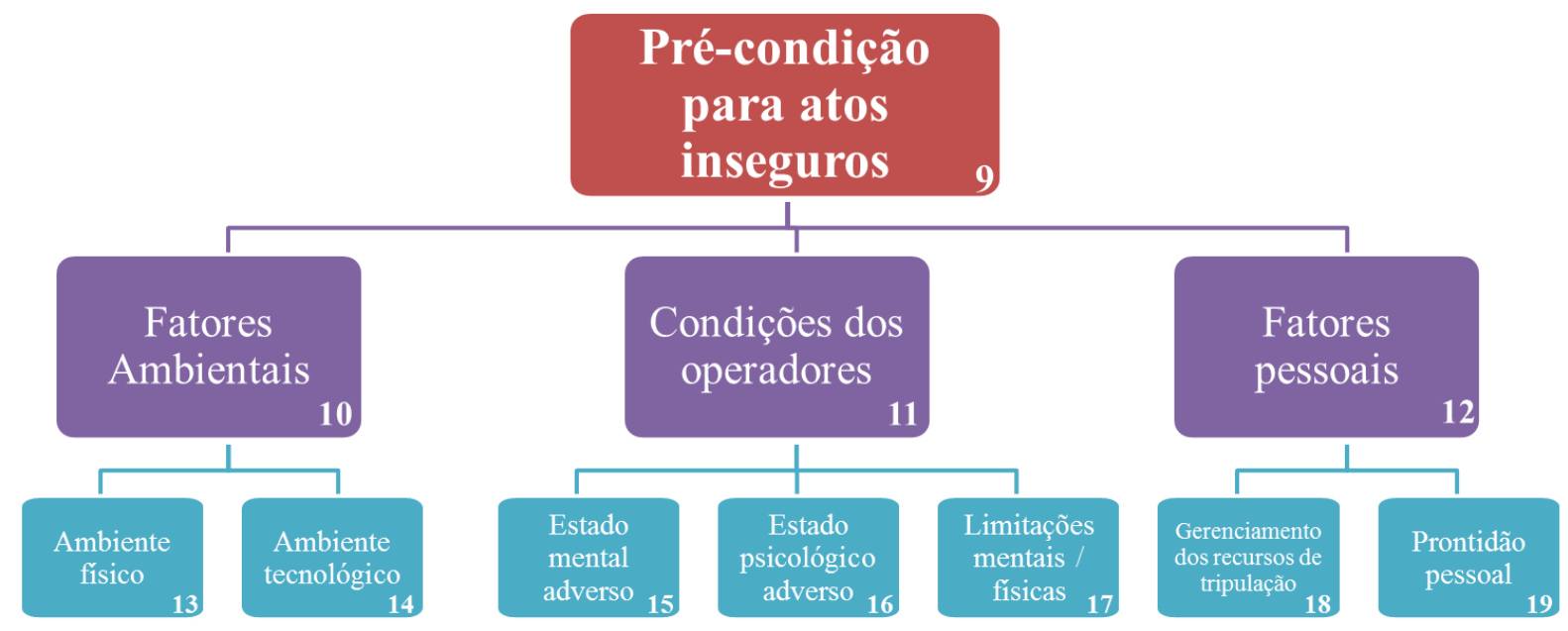

Figura 2.9 - Segundo nível do método HFACS. (tradução livre, modificada - Wiegmann \& Shappell, 1997).

Quanto aos fatores do segundo nível de classificação (9), que é da pré-condição para atos inseguros (Fig. 2.9), também se encontram diversas áreas que podem ser diminuídas, por exemplo, por meio de treinamentos ligados à segurança. Os fatores ambientais (10), especialmente os físicos (13) podem ser minimizados por meio de treinamento para reconhecer esses fatores e evitá-los, uma vez que não se pode controlá-los, como em situações de baixa visibilidade ou outras Condições de Voo por Instrumentos ${ }^{4}$. Assim, pode-se considerar a importância do treinamento dos pilotos para operar sob Regras de Voo por Instrumentos 5 .

Quanto ao ambiente tecnológico (14), o conhecimento do piloto com relação ao equipamento que utiliza (avião, sistemas de navegação, aeroporto) é essencial e tem ligação direta com a interação liveware - software do Modelo SHELL, abordado no capítulo 2.7 da presente dissertação. Em relação às condições dos operadores (11), o treinamento voltado à segurança já não estaria ligado diretamente aos pilotos, a não ser que fossem elaborados treinamentos sobre como lidar $(15,16$ e 17) e explicar ao operador da aeronave do risco envolvido em determinado tipo de operação (sob condições meteorológicas adversas, por exemplo).

Nos fatores pessoais (12), o gerenciamento de recursos de cabine (18) são fatores muito discutidos na aviação regular nos últimos anos, como por exemplo, nos cursos de Crew

\footnotetext{
${ }^{4}$ Instrument Meteorological Conditions (IMC) (tradução livre)

${ }^{5}$ Instrument Flight Rules (IFR) (tradução livre)
} 
Resource Management $(C R M)^{6}$ realizados regularmente. No entanto, o fato de não ser obrigatória, e, portanto, extremamente pequena a quantidade de acidentes com presença de copiloto, a análise desse fator acaba por perder relevância. A prontidão pessoal do piloto (19) necessita de verificação, pois a relação de trabalho costuma ser extremamente variável nessa profissão, principalmente na categoria aviação geral.

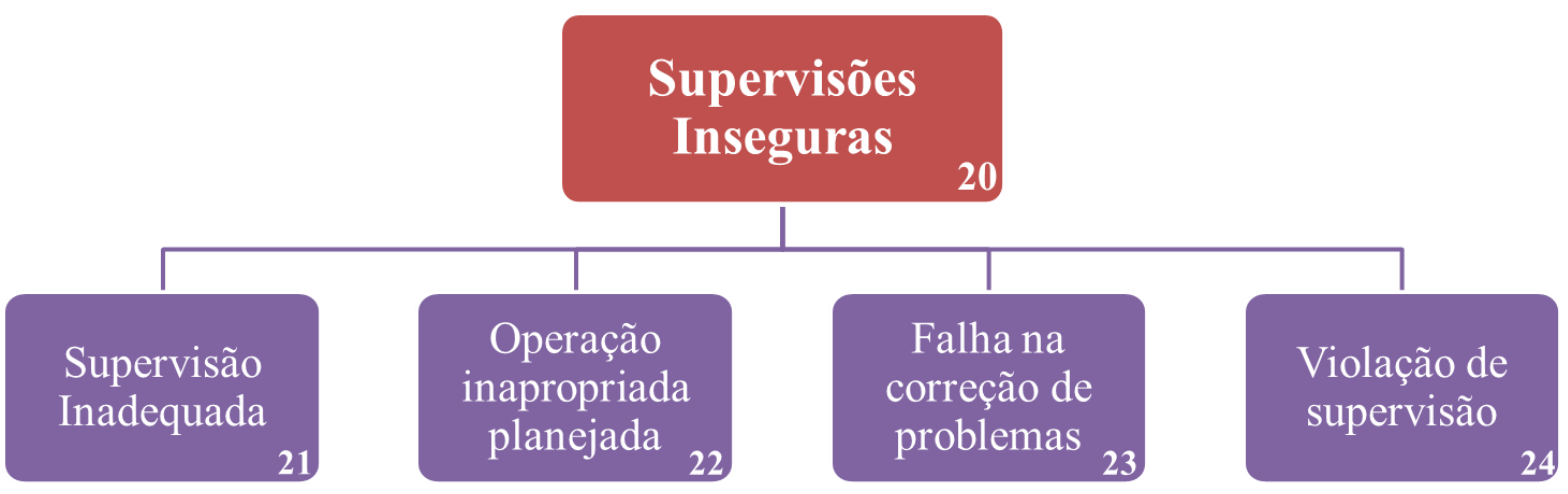

Figura 2.10 - Terceiro nível do método HFACS (tradução livre, modificada - Wiegmann \& Shappell, 1997).

O terceiro nível do método HFACS (Fig. 2.10), das supervisões inseguras (20), também tem ligação direta com a formação do piloto, especialmente quanto à segurança de voo. Considerando a supervisão inadequada (21), ela pode acontecer devido à falta de consciência do piloto com relação à importância da mesma, bem como características do seu planejamento. A operação inapropriada planejada (22) pode ter origem em uma cultura de não segurança no meio e pode ser diminuída com cursos e treinamentos constantes sobre a segurança de voo e sua importância. A falha na correção dos problemas (23) pode ter origem na falta de conhecimento sobre o que seja importante ser supervisionado e como isso deve ser feito. Sobre o último item (24), acredita-se que, a partir do instante que o piloto tem consciência dos efeitos positivos de uma supervisão segura, dificilmente violará essa etapa.

\footnotetext{
${ }^{6}$ Gerenciamento dos Recursos de Tripulação (tradução livre).
} 


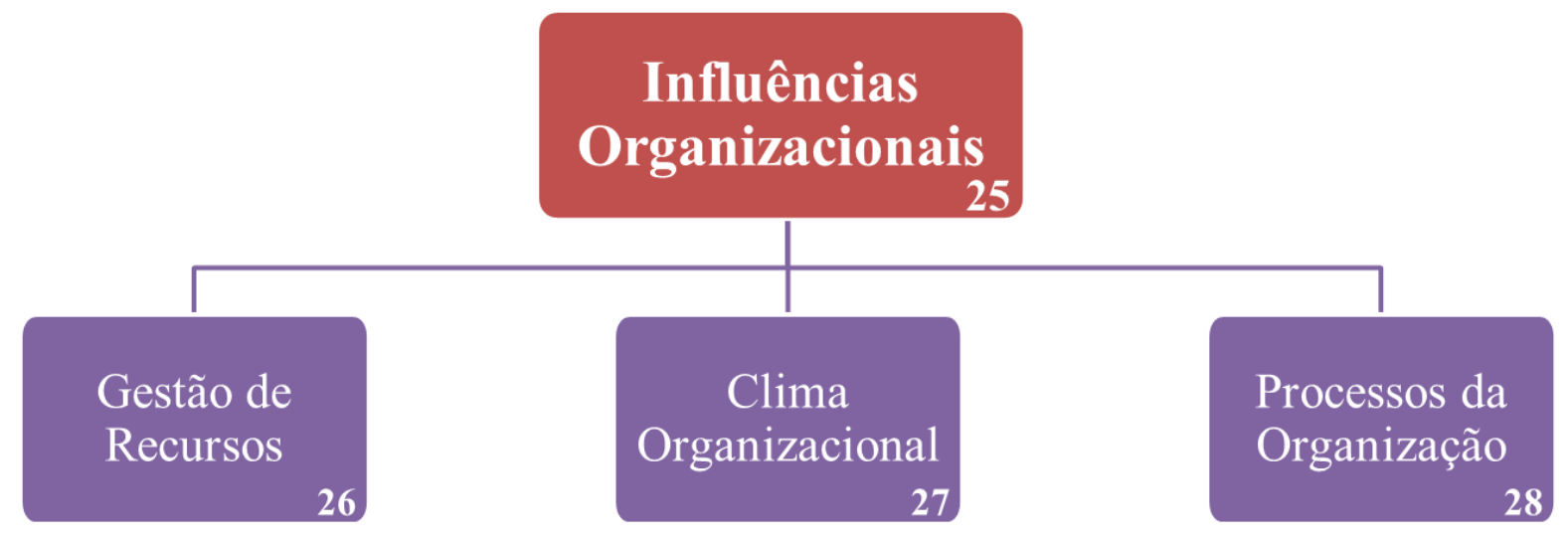

Figura 2.11 - Quarto nível do método HFACS (tradução livre, modificada - Wiegmann \& Shappell, 1997).

O quarto nível (Fig. 2.11), de influências organizacionais (25) é particularmente desafiador para a aviação geral, pois no setor considerado (Serviço Aéreo Privado), muitas vezes a organização em questão é reduzida, se limitando ao proprietário do avião e seu (s) piloto (s). O controle dos processos (28), a variação do clima organizacional 27) e a própria gestão de recursos (26) ficam reduzidos e esquecidos, sendo por vezes negligenciados pelos pilotos ou pelos proprietários. Investigações sobre o nível de conhecimento dos envolvidos com o quarto nível desse método são essenciais para a segurança de voo.

\section{5 - RELATÓRIOS DE ACIDENTES AERONÁUTICOS}

Os relatórios finais de acidentes aeronáuticos são públicos e podem ser encontrados na página de internet do Cenipa (http://www.cenipa.aer.mil.br). Ao clicar no link "Relatórios Finais", o site abre uma nova página com o motor de busca dos Relatórios disponíveis a partir de 2005. Verifica-se que, ao clicar no link para abrir a ocorrência, o Cenipa apresenta a página de Recomendação de Segurança de Voo, com a data do acidente e matrícula da aeronave (essenciais para a identificação do acidente específico) e um breve histórico do acidente.

Apesar do título da página (Recomendação de Segurança de Voo), em alguns acidentes da aviação geral, não se encontrou recomendações, mesmo sendo possível identificar possíveis melhorias e recomendações considerando a segurança de voo ao se analisar o que foi levantado no relatório de acidente. Nessa página, tem-se a opção de solicitar encaminhamento ao relatório final do acidente. Ao clicar no link "Relatório Final", é aberta uma nova página, que deixa claro o objetivo da investigação que é o de permitir "o estudo e o estabelecimento de providências de caráter preventivo", que vão ao encontro do objetivo desse trabalho. Outro motivo para o destaque desse aviso pelo órgão está em se evitar que seus relatórios sejam utilizados para fins punitivos ou de incriminação.

Notou-se que, em alguns casos, especialmente os mais recentes em que o Relatório Final ainda não está disponível, tem-se disponível o "Relatório Final Simplificado" (SUMA), em 
que a descrição e conclusão sobre os fatores não é completa, e, portanto, não foi utilizada nesse trabalho. Ressalta-se ainda que nessa dissertação foram consideradas as datas de ocorrência dos acidentes, e não de publicação dos relatórios, a fim de uma correta definição de período de acidentes.

\section{6 - SEGURANÇA DE VOO NA AVIAÇÃO GERAL}

No panorama estatístico publicado pelo Cenipa, divide-se a aviação civil em diferentes categorias (Brasil, 2014c), sendo que três delas possuem como atividade principal o transporte de passageiros: aviação regular, taxi aéreo e aviação geral. O que mais chama a atenção no panorama estatístico é a participação da aviação geral nos acidentes aeronáuticos, muito superior à das outras categorias, conforme mostra a Fig. 2.12.

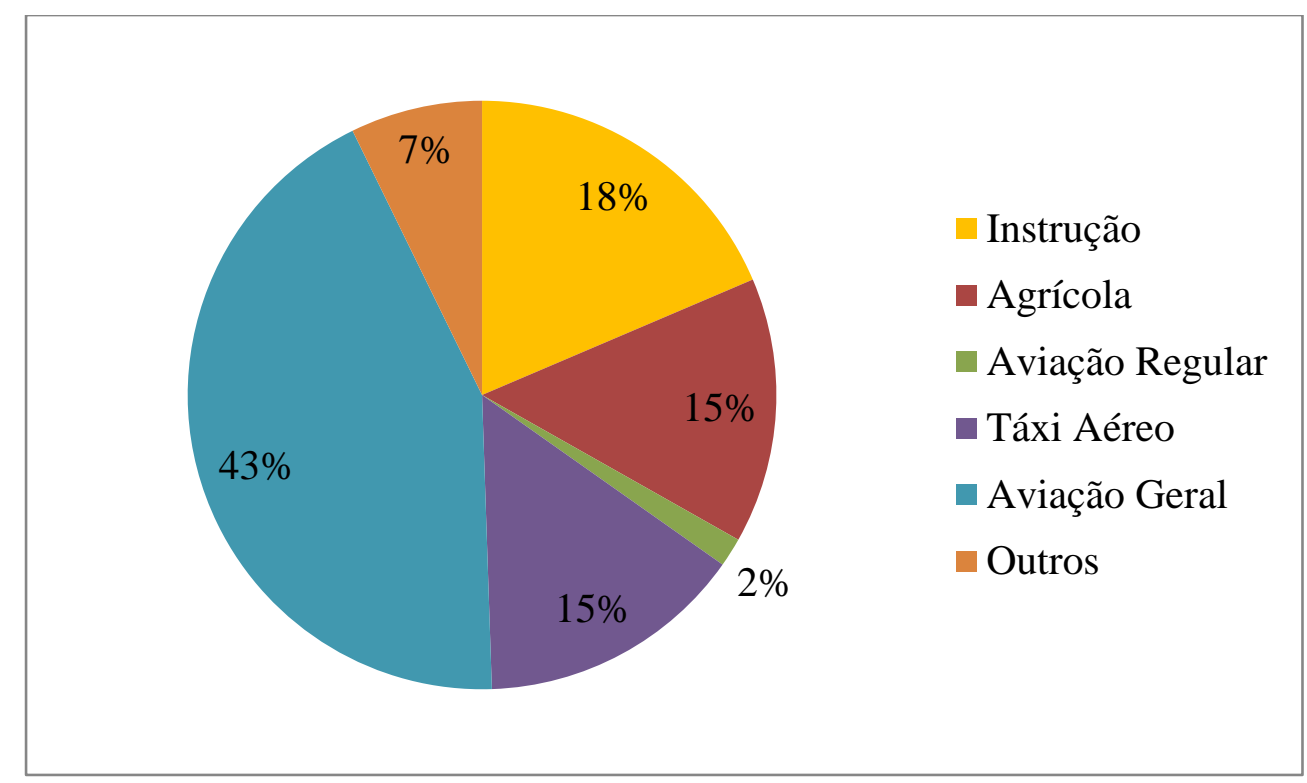

Figura 2.12 - Quantidade de acidentes em 2013 por categoria (modificada - Brasil, 2014c).

Se forem considerados todos os acidentes ocorridos no período entre 2004 e 2013 (Fig. 2.12), a aviação geral foi responsável por $43 \%$ dos acidentes na aviação civil, enquanto a aviação regular, que também faz o transporte de passageiros, por exemplo, foi responsável por apenas $2 \%$ no mesmo período (Brasil, 2014).

\section{7 - ELEMENTO HUMANO "PILOTO" NA AVIAÇÃO GERAL}

Para se pilotar um avião, é necessário possuir habilitação suficiente para o equipamento. Alguns aviões, como a maioria dos convencionais - movidos por conjunto pistão-hélice necessitam de licença de "Classe", por serem considerados de operação simples e semelhante, não sendo necessário curso específico. Aviões de maior porte e complexidade requerem um treinamento avançado e focado apenas na sua operação, sendo necessário que o piloto obtenha a licença de "Tipo" (Brasil, 2012b), que torna esses profissionais mais valorizados e reconhecidos no mercado (Stolt \& Ensslin, 2009). Esse reconhecimento faz sentido quando se 
considera o conhecimento específico do piloto sobre aquele sistema (hardware + software) conforme pode ser verificado no modelo SHELL (Hawkins, 1984), recomendado a comunidade científica de países signatários da OACI para análises sobre fatores humanos (Barreto, 2008).

O modelo SHELL, que começou a ser desenvolvido por Edwards em 1972, foi modificado e publicado por Hawkins em 1984 (Hawkins, 1984). Esse modelo é representado num diagrama de blocos dentados (Fig. 2.12), significando as interfaces entre os elementos do sistema e indicando que é necessário um ajuste cuidadoso entre esses blocos para evitar sobrecarga no sistema e eventual ruptura.

O que garante a robustez do emprego desse modelo nas análises do presente trabalho é o fato de considerar o ser humano como elemento central de um sistema complexo, considerando o seu inter-relacionamento com outras interfaces, quais sejam: programação (software); equipamento (hardware); ambiente (environment); ser humano (liveware) e outros seres humanos (liveware) (Hawkins, 1993). Essas relações são demonstradas na Fig. 2.13.

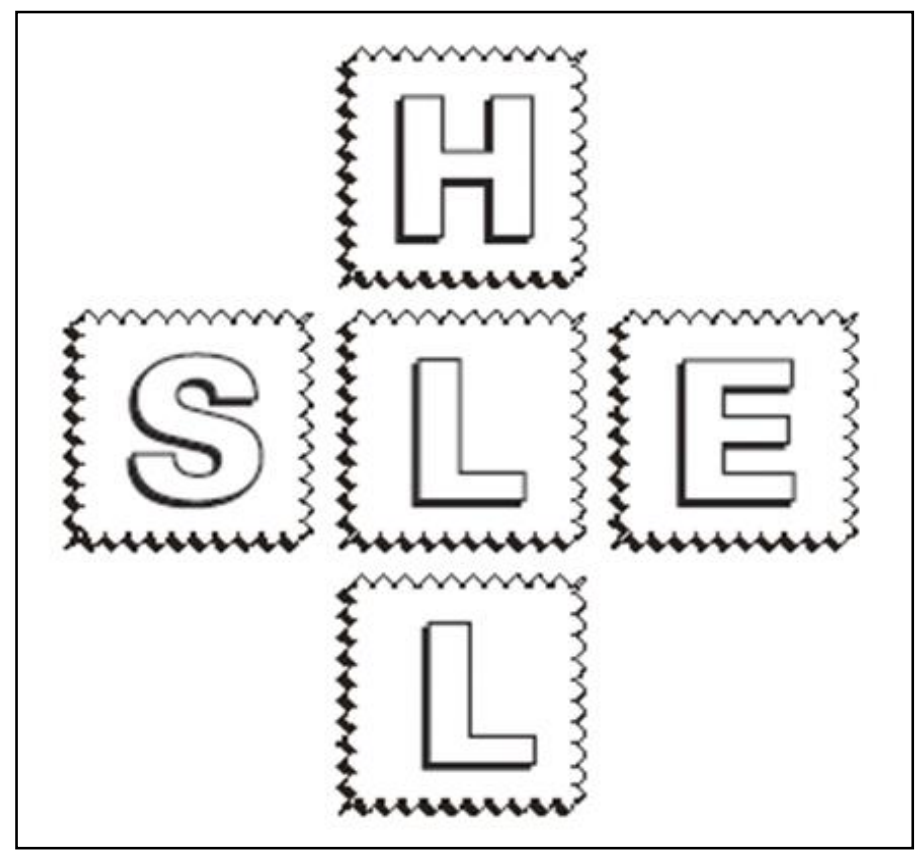

Figura 2.13 - Modelo SHELL (modificada - Hawkins, 1984).

Nesse modelo, o encaixe dos blocos, ou seja, as interfaces são tão importantes quanto às próprias características dos blocos, pois a falta de encaixe pode ser fonte de erro pelo elemento que se encontra no centro da Fig. 2.13 (Liveware). Isso explica, inclusive, porque o ser humano aparece duas vezes: pode ocorrer uma falha na integração entre dois blocos humanos, como um piloto e um controlador de voo ou mecânico, por exemplo.

Além das conclusões de Santi (2009) sobre a eficiência da prevenção por meio de treinamento e conhecimento dos pilotos, diversos autores afirmam que aviões turboélice e pistão-hélice - 
que compõem a maior parte da frota de aeronaves da aviação geral - estão mais sujeitos a acidentes pelo fato dos pilotos não receberem treinamento suficiente nessas aeronaves (Araújo \& Bezerra, 2007; Fangueiro, 2008; Stolt \& Ensslin, 2009). Esses autores identificam que tripulantes consideram aeronaves a pistão como equipamentos de menor complexidade e que a experiência nesse tipo de equipamento acaba por não agregar valor às horas de voo (experiência do piloto) pela baixa capacitação envolvida.

\section{3 - FERRAMENTAS, PROCEDIMENTOS E MÉTODOS}

\section{1 - APRESENTAÇÃO}

Diversas tecnologias têm surgido tanto para a obtenção quanto para o tratamento e análise de dados de amostras ou populações grandes e pequenas. O objetivo desse trabalho não é se aprofundar em características específicas das ferramentas utilizadas ou de seu desenvolvimento na área da ciência da computação, mas explorar o potencial analítico de seus resultados.

Foi adotada a abordagens interdisciplinar, por buscar criar conhecimento a partir da integração entre as áreas da Ciência da Computação e da Engenharia de Transportes em todas as etapas do trabalho, conforme recomendado por Cardella (1999). Após a coleta e organização dos dados, essa abordagem foi colocada em prática por meio do método hipotético-indutivo com a identificação de padrões mais representativos nos acidentes.

Para tanto, utilizou-se a Inteligência Artificial por meio do método de Aprendizado de Máquina conhecido como Floresta de Caminhos (OPF) (Papa, 2008). Foi utilizado o método não-supervisionado, visando não interferir no estabelecimento desses padrões, conhecidos na ciência da computação por "clusters". O estabelecimento desses clusters nada mais é do que uma técnica de Data Mining que visa realizar agrupamentos automáticos de dados segundo seu grau de semelhança. Os critérios de semelhança entre aspectos selecionados para o algoritmo fazem parte da definição do problema a ser analisado (Papa, 2008).

Os padrões buscados consideraram características como formação e experiência dos pilotos, quantidade de motores das aeronaves e de fatores contribuintes, fatalidades, aspectos dos fatores contribuintes, e presença ou ausência de copiloto. A partir dos padrões obtidos, foram analisadas as possíveis falhas no sistema da aviação geral, buscando compreender a relação entre essas características e os fatores contribuintes dos acidentes.

\section{2 - COLETA E ORGANIZAÇÃO DE DADOS DOS ACIDENTES}

A coleta e organização dos dados dos Relatórios Finais de acidentes da aviação geral foi dividida nas três partes que se seguem: primeiro foi realizado o levantamento de todos os registros de acidentes da aviação geral (Cap. 3.2.1), para depois ser verificada a disponibilidade dos Relatórios Finais no site do Cenipa (Cap. 3.2.2), e por fim foi realizada a 
coleta e organização desses dados (Cap. 3.2.2). Trata-se, portanto, da população de dados disponíveis nos Relatórios Finais do Cenipa, considerando a aviação geral.

\subsection{1 - LEVANTAMENTO DOS REGISTROS DE ACIDENTES DA AVIAÇÃO GERAL}

Nessa primeira parte, foram solicitadas informações tabuladas sobre os relatórios de acidentes ao Cenipa. O órgão respondeu prontamente, enviando duas planilhas com dados de todos os acidentes registrados nos últimos dez anos da pesquisa (período de 2005 a 2015).

A primeira planilha, denominada "Fatores Contribuintes", possuía quatro variáveis (nas colunas), sendo elas: "Matrícula da Aeronave"; "Classificação da Ocorrência"; "Data da Ocorrência"; e "Nome do Fator Contribuinte". Cada linha dessa planilha representava as informações de um mesmo acidente. No entanto, por considerar apenas os fatores "contribuiu" e não possuir os fatores "indeterminado" optou-se por não utilizar essa planilha. Esses fatores "indeterminado" são aqueles que o investigador levanta como possível de ter ocorrido, mas não possui meios para prová-lo, mas que são considerados, no presente trabalho, como relevantes, visto que o objetivo é explorar ao máximo todos os fatores.

A segunda planilha, denominada "Ocorrências", possuía 10 variáveis, sendo elas "Matrícula da Aeronave", "Classificação da Ocorrência", "Data da Ocorrência", "Tipo de Ocorrência", "Estado", "Cidade", "Categoria de Registro da Aeronave", "Tipo de Aviação", "Modelo da Aeronave" e "Tipo de Operação". Nessa segunda planilha, foram encontrados 543 registros de acidentes que eram considerados, pelo Cenipa como sendo da categoria aviação geral. No entanto, percebeu-se que o órgão também inclui na categoria aviação geral, outras categorias, pois o órgão considera como aviação geral todas as aeronaves que não fazem parte da aviação regular. Portanto, nesses 543 registros, constavam aeronaves dedicadas a atividades relacionadas, por exemplo, à Instrução, Táxi Aéreo, Agrícola e Múltipla, que possuem exigências e características muito diferentes do que se considera como aviação geral.

Para chegar ao total de acidentes exclusivamente relacionados à aviação geral, foram realizadas seis etapas explicadas a seguir.

\subsubsection{1 - $1^{\text {a ETAPA }}$}

Foram considerados apenas os registros da coluna "Tipo de Aviação" que estavam com rótulo "Aviação Geral", restando um total de 281 registros de acidentes.

\subsubsection{2 - 2a ETAPA}

Percebeu-se a existência de relatórios de acidentes dos Serviços Aéreos Especializados (SAE), que não são objeto de estudo desse trabalho por não terem o transporte de passageiros como atividade fim, e sim como consequência de outra atividade, como por exemplo, a 
pulverização aérea, os serviços de bombeiros ou de fotogrametria. Depois de excluídos os acidentes de SAE, restaram 255 relatórios de acidentes.

\subsubsection{3 - $3^{\text {a }}$ ETAPA}

Essa etapa exigiu consulta ao banco de dados público do Registro Aeronáutico Brasileiro (RAB, 2015), utilizando o prefixo de matrícula de cada uma dessas 255 aeronaves para categorizá-las como de asa fixa (aviões) ou asas rotativas (helicópteros).

Nessa análise, foram excluídos também, além dos Helicópteros (Fig. 3.1), os Motoplanadores Fig. 3.2), que são planadores com pequenos motores, geralmente utilizados para desporto.
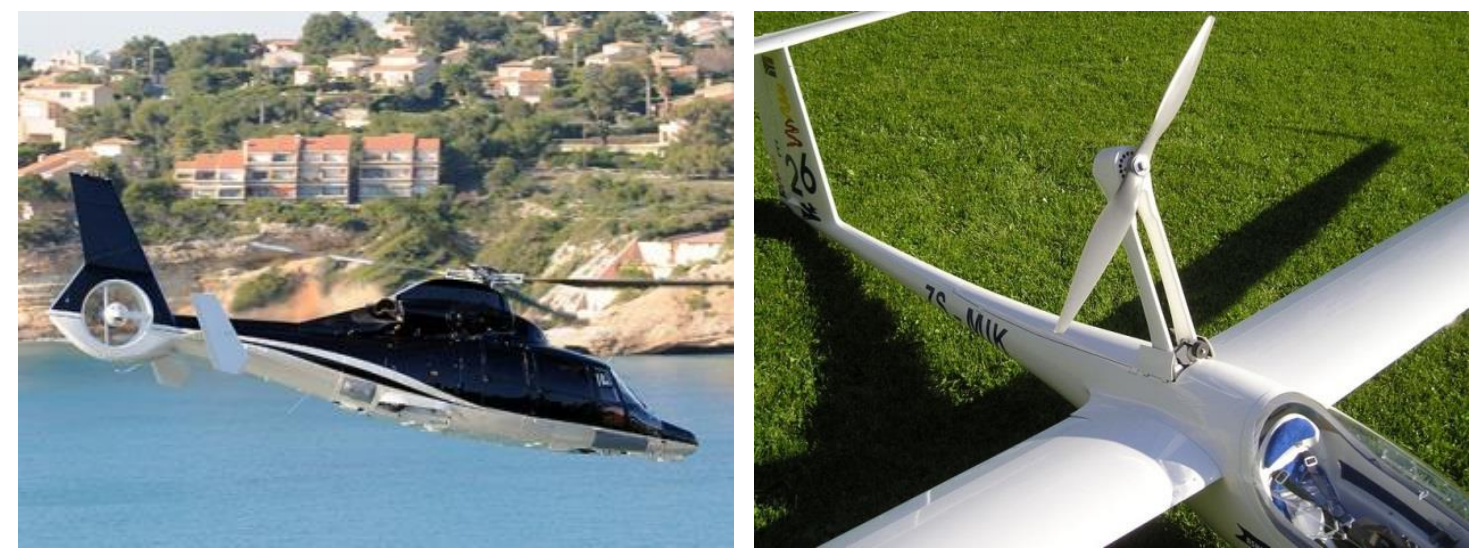

Figura 3.1 - Helicóptero AS365 N3+ (Helibras, 2015).

Figura 3.2 - Motoplanador ASH 26 (Let Model (2015).

Foram excluídos também os "Jatos", que são as aeronaves que utilizam motores a jato (Fig. 3.3) ou turbo-fan (Fig. 3.4), restando 182 registros de acidentes.
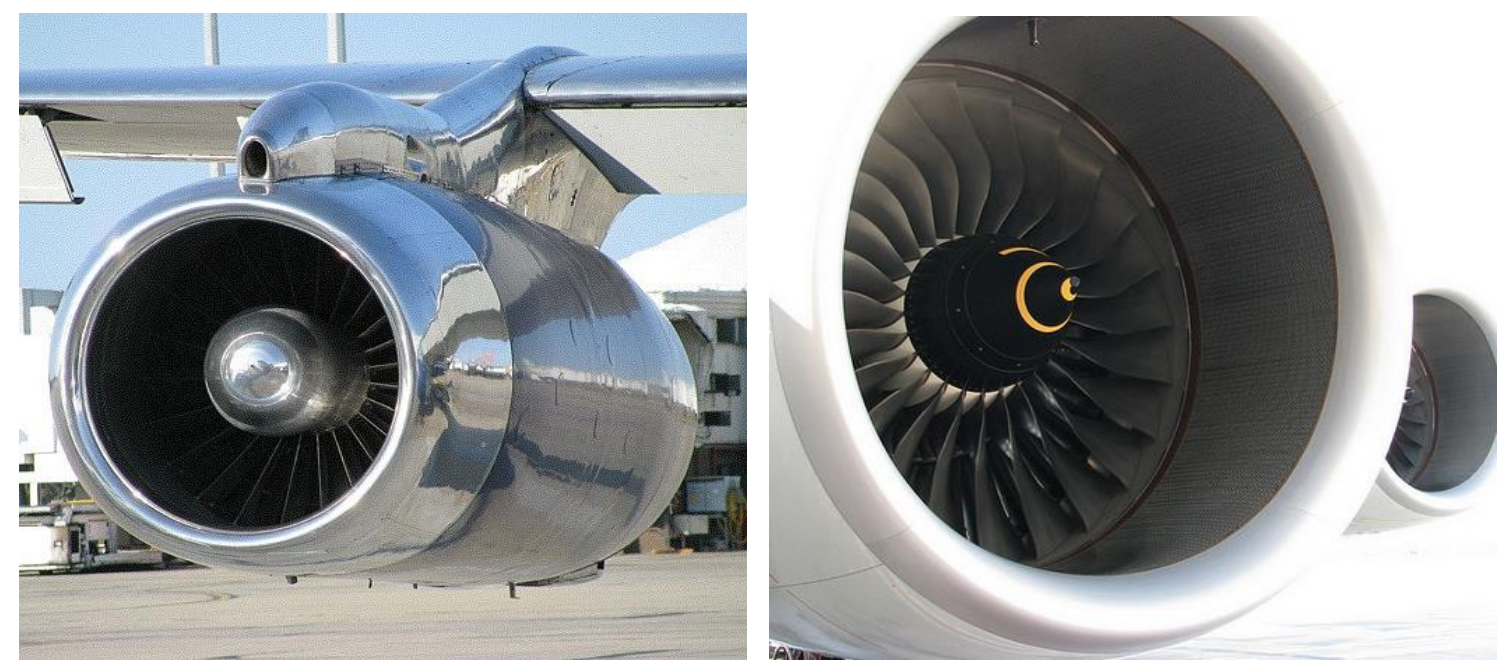

Figura 3.3 - Motor a Jato (Flickr de brucek68, 2015).

Figura 3.4 - Motor turbo-fan (Flickr de brucek68, 2015). 


\subsubsection{4 - $4^{\text {a ETAPA }}$}

Essa etapa também exigiu consulta ao banco de dados público do Registro Aeronáutico Brasileiro (RAB, 2015) para que fossem analisados os modelos de aeronaves. Nessa análise, foram identificadas 23 aeronaves que são tipicamente utilizadas para serviços de pulverização agrícola ou para atividades aéreas dos bombeiros, sendo 21 do modelo EMB-202/EMB-202a (Fig. 3.5), e duas do modelo AT-802/AT-802 (Fig. 3.6).

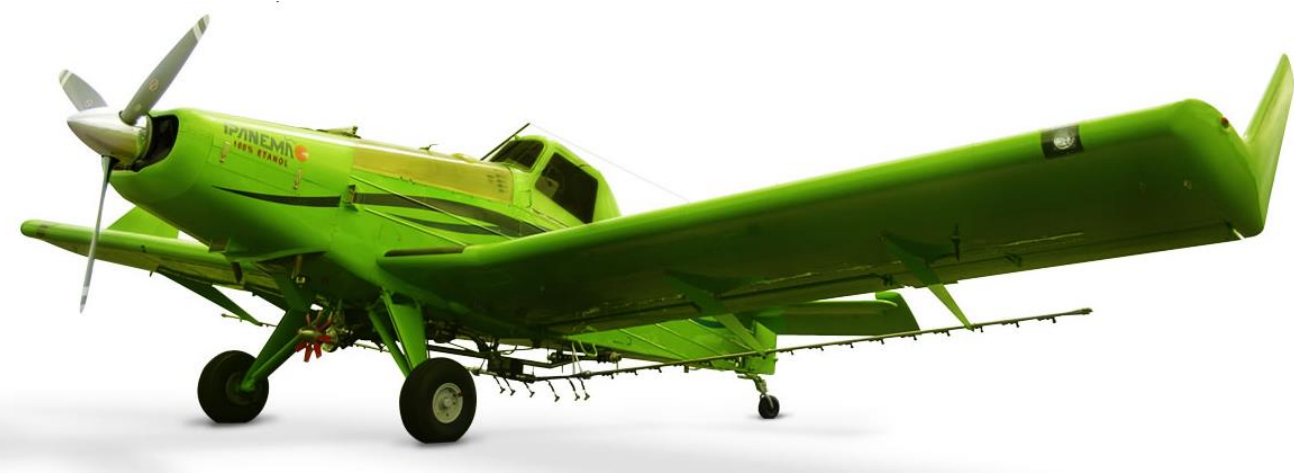

Figura 3.5 - EMB202A Ipanema. (Piper, 2015).

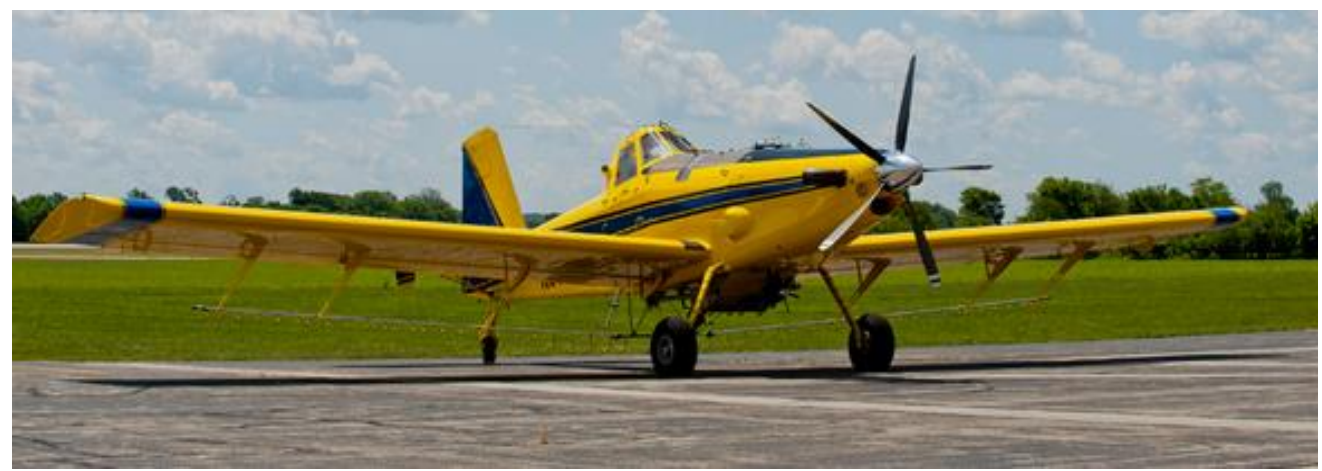

Figura 3.6 - AT-802A (Air Tractor, 2015).

Por não executarem o mesmo tipo de atividade que as outras aeronaves da aviação geral, essas 23 aeronaves foram excluídas da planilha, restando 159 relatórios.

\subsubsection{5 - 5 ETAPA}

Visando unificar a legislação referente às exigências de treinamento dos pilotos e considerando o modelo da aeronave levantado anteriormente junto ao banco de dados público do Registro Aeronáutico Brasileiro (RAB), encontrou-se que nove desses acidentes ocorreram com aeronaves "Tipo", que não se enquadram no problema de pesquisa desse trabalho por exigirem treinamento específico do piloto na aeronave a ser voada, sendo desconsideradas nessa etapa da triagem. Restaram, portanto, 150 registros de acidentes, todos de aeronaves "Classe", em que pilotos não realizam treinamento específico para operá-las. 


\subsubsection{6 - 6 ${ }^{\text {a ETAPA }}$}

Dos 150 registros, 143 se enquadravam na Categoria de Registro de Aeronave "Serviços Aéreos Privados (TPP)", três na Categoria de Registro de Aeronave "Administração Direta Estadual (ADE)", e uma na Categoria de Registro de Aeronave "Administração Direta Federal (ADF)”. Notaram-se também três aeronaves de matrícula estrangeira.

Optou-se por desconsiderar todos os registros de Categoria de Registro de Aeronave que não fossem "Serviços Aéreos Privados (TPP)", mantendo as três aeronaves de matrícula estrangeira por executarem o mesmo tipo de atividade para o mesmo tipo de operador, restando 146 registros considerados doravante como os Registros de Acidentes da Aviação Geral no período 2005 a 2015. As seis etapas e a quantidade de relatórios em cada uma delas pode ser verificada na Fig. 3.7.

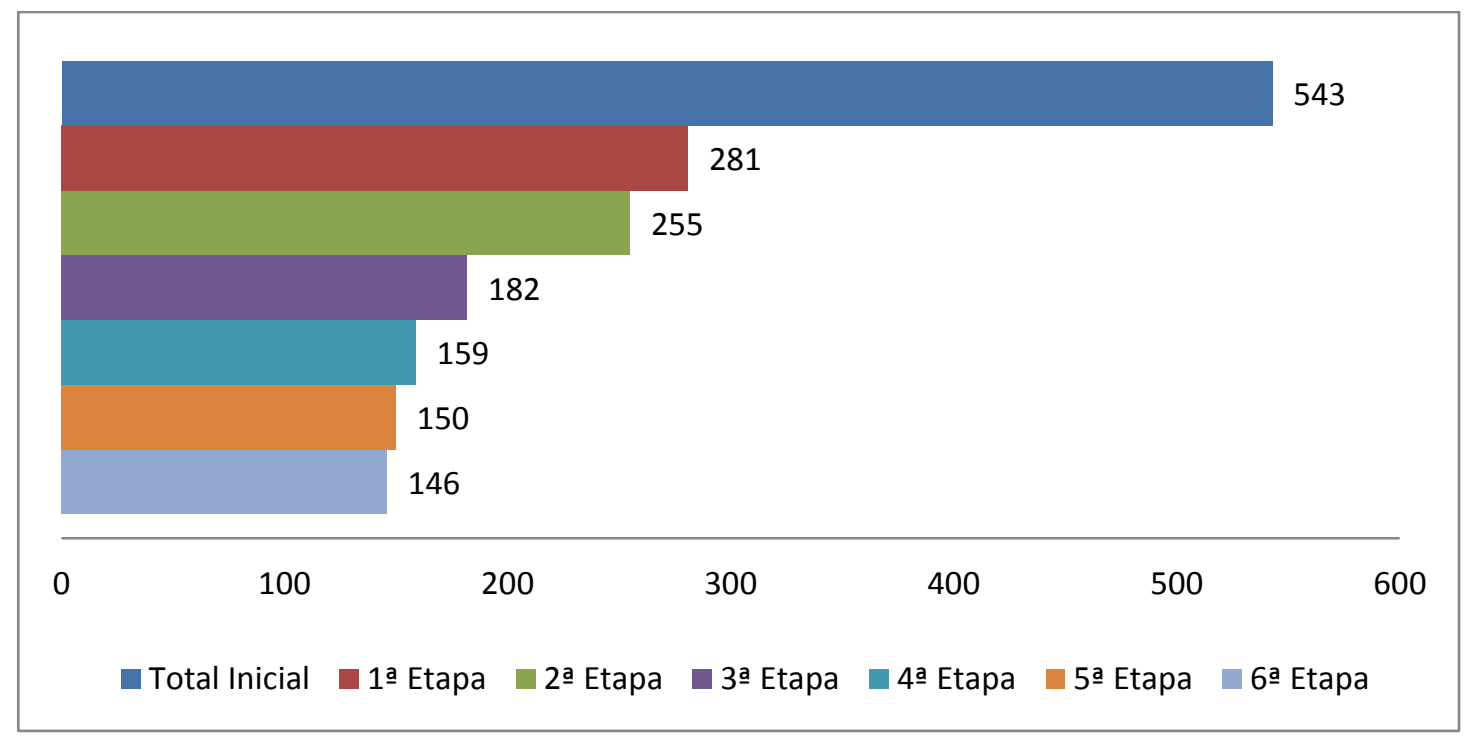

Figura 3.7 - Quantidade de Relatórios por Etapa (elaborada pelo autor).

A Figura 3.7 mostra a quantidade total inicial de registros com base na planilha enviada pelo Cenipa e a quantidade final que foi considerada nesse trabalho como quantidade total de Registros de Acidentes da Aviação Geral no período 2005 a 2015.

\subsection{2 - ANÁLISE DA DISPONIBILIDADE DOS RELATÓRIOS FINAIS}

Nessa etapa, buscaram-se os Relatórios correspondentes aos Registros de Acidentes da Aviação Geral no período 2005 a 2015. Notou-se, na página inicial dos Relatórios (Brasil, 2015c), o seguinte aviso: "Estão disponibilizados os Relatórios produzidos a partir de 2007”. Apesar disso, foram verificados todos os relatórios disponíveis, considerando os Registros de Acidentes da Aviação Geral no período 2005 a 2015 identificados na $1^{\text {a }}$ Parte, encontrando-se a quantidade de 97 resultados, sendo que quatro deles consistiam apenas "Relatório Final 
Simplificado" (SUMA) e não dispunham de boa parte dos dados e informações disponibilizados nos Relatórios Finais, restando portanto, 93 relatórios a serem analisados.

Os 93 Relatórios Finais encontrados se dividiam por ano conforme se apresenta na tabela 3.1.

Tabela 3.1 - Quantidade de Relatórios Finais por Ano (elaborada pelo autor).

\begin{tabular}{cc}
\hline Ano & Quantidade \\
\hline $\mathbf{2 0 0 5}$ & 3 \\
$\mathbf{2 0 0 6}$ & 4 \\
$\mathbf{2 0 0 7}$ & 10 \\
$\mathbf{2 0 0 8}$ & 18 \\
$\mathbf{2 0 0 9}$ & 22 \\
$\mathbf{2 0 1 0}$ & 13 \\
$\mathbf{2 0 1 1}$ & 17 \\
$\mathbf{2 0 1 2}$ & 5 \\
$\mathbf{2 0 1 3}$ & 1 \\
\hline TOTAL & 93 \\
\hline
\end{tabular}

Consideraram-se, portanto, esses 93 acidentes como população de acidentes da aviação geral com relatórios finais disponíveis.

\subsection{3 - COLETA E ORGANIZAÇÃO DE DADOS DOS RELATÓRIOS FINAIS}

Foi realizada a coleta de dados dos 93 Relatórios Finais, reunindo-se os dados considerados mais padronizados e importantes ao presente trabalho, que compõem as variáveis analisadas no mesmo. A seguir, foi realizada uma breve explicação sobre o tipo de dado e sua relevância para as análises, bem como as observações relacionadas a cada um deles. Nos casos em que se julgou necessário fazer alguma observação sobre especificidades de algum relatório, o mesmo foi citado por meio da matrícula da aeronave, designada pelos dois caracteres de nacionalidade $(\mathrm{XX})$, seguidos pelos três caracteres marca de matrícula (YYY), formando XXYYY, conforme se segue.

\subsubsection{1 - MATRÍCULA DA AERONAVE}

A matrícula trata da identificação da aeronave. De acordo com o Registro Aeronáutico Brasileiro (RAB, 2015), a matrícula é o primeiro registro de uma aeronave no Brasil e consiste na atribuição de uma marca a esta aeronave. Cada aeronave possui uma matrícula própria e cada combinação de marcas pode ser atribuída a apenas uma aeronave, ou seja, as marcas de matrícula de uma aeronave são o grupo de caracteres identificadores de uma aeronave civil próprio de sua nacionalidade e decorrente de seu registro. 
Estas marcas são representadas por cinco caracteres alfabéticos: os dois primeiros são as marcas de nacionalidade, que no caso de aeronaves brasileiras são designados os caracteres PT, PP, PR ou PU, que indicam a nacionalidade brasileira; e os três últimos são as marcas de matrícula. Considerando as análises desse trabalho, a matrícula auxilia no sentido de rotular cada relatório de acidente.

\subsubsection{2 - QUANTIDADE DE FATORES “CONTRIBUIU”}

A quantidade de fatores "contribuiu" do Relatório Final de um determinado acidente representa os fatores que o órgão determinou, após a investigação, terem influenciado diretamente e comprovadamente a ocorrência do acidente.

\subsubsection{3 - QUANTIDADE DE FATORES "INDETERMINADO"}

Os fatores que o órgão não conseguiu determinar, após a investigação, como fatores que tenham influenciado diretamente na ocorrência do acidente são quantificados como “indeterminado". Apesar de não serem comprovados, são fatores considerados pelo órgão como relevantes a ponto de serem considerados nos relatórios e são, portanto, também considerados nesse trabalho.

\subsubsection{4 - QUANTIDADE TOTAL DE FATORES}

Ao se referir à quantidade total de fatores, trata-se da soma dos fatores contribuintes considerados como "indeterminado" e "contribuiu" nos Relatórios Finais.

\subsubsection{5 - TIPOS DE FATORES}

Após o levantamento das quantidades de fatores ("indeterminado" e "contribuiu"), foram criadas colunas para cada um dos fatores contribuintes específicos dentro dos aspectos dos Fatores Operacionais, Humanos e Materiais.

É importante ressaltar que, considerando o foco desse trabalho na prevenção centrada no piloto, alguns fatores foram "separados" de acordo com a descrição de sua ocorrência, sendo acrescentada a coluna "Fator" + "Outros" nesses casos. É o exemplo de "Supervisão - outros" para os casos em que a supervisão não estava ligada à responsabilidade do piloto, mas de outros envolvidos no processo. Para o fator específico de nome "Outros", foi realizado o mesmo processo, separando os fatores "Outros" ligados ao piloto daqueles relacionados a outras partes do sistema.

Em alguns casos, como do PT-LKH, em que uma aeronave modelo A-36 Bonanza perdeu o controle em voo em condições meteorológicas pesadas, o Cenipa atribuiu o fator "Julgamento", e não "Julgamento de Pilotagem", bem como "Planejamento", e não "Planejamento de voo". No entanto, referem-se a fatores que foram relacionados ao 
julgamento e ao planejamento do próprio piloto, sendo colocados, portanto, nas categorias específicas. Ainda nesse relatório, não foram estabelecidos os fatores contribuintes específicos psicológicos, sendo estes apenas citados dentro da categoria, de forma a serem estabelecidos pelo autor desse trabalho, os seguintes fatores: "Humanos - Psicológico Individual - Humanos - Processo Decisório", "Humanos - Psicológico - Individual Percepção", e "Humanos - Psicológico - Individual - Invulnerabilidade", por meio do texto a seguir.

\footnotetext{
"Possíveis traços de invulnerabilidade, elevada auto estima (sic) e excesso de autoconfiança do piloto teriam comprometido sua capacidade de percepção e de tomada de decisão, levando-o a concluir que, mesmo com as condições meteorológicas desfavoráveis, conseguiria pousar no aeródromo de destino." Pela palavra "possíveis", resolveu-se categorizar esse fator como "indeterminado", e não como "contribuiu"(Brasil, 2015d, p.13).
}

No relatório do acidente do PR-RAT, de uma aeronave modelo Cirrus SR20 que efetuou um pouso muito longo e ultrapassou os limites da cabeceira da pista, verificou-se falta de padronização no termo do fator "Infraestrutura" ao se referir à "Infraestrutura Aeroportuária", mas o conteúdo do fator encontrava-se nos mesmos moldes de outros fatores de "Infraestrutura Aeroportuária", sendo considerado, portanto, nessa categoria.

Houve um caso em que o relatório (PT-DON), de uma aeronave modelo PA-24-260 que arremeteu na reta final e realizou curva à esquerda, perdendo altura até colidir com o solo, indicava como fator a "tomada de decisões", que foi considerado como "Humano Operacional - Processo decisório" pelo fato das explicações serem semelhantes com relação ao conteúdo.

No relatório do acidente PT-VHK, de uma aeronave modelo EMB-711 ST que colidiu em voo com a encosta de uma serra encoberta por nuvens após a decolagem, não foram aprofundados os fatores humanos psicológicos, tendo sido estabelecidos por esse autor, com base nos textos, os fatores "Humanos - Psicológicos - Individuais - Processo Decisório", e "Humanos Psicológicos - Individuais - Percepção” como fatores indeterminados.

No relatório do acidente PT-OOH, de uma aeronave modelo BE-60 com esgotamento de combustível durante o voo (pane seca) não foram aprofundados os fatores humanos psicológicos, tendo sido estabelecidos, portanto, com base nos textos, como fatores "Humanos - Psicológicos - Individuais - Percepção", "Humanos - Psicológicos - Individuais - Descaso com Normas e Procedimentos", e "Humanos - Psicológicos - Individuais Processo decisório". O texto não afirma serem fatores "contribuiu", portanto, optou-se por categorizar esses fatores como "indeterminado".

No relatório do acidente PT-KEZ, uma aeronave modelo BE-V35B com falha de motor em voo após a decolagem, não foram aprofundados os fatores humanos psicológicos, tendo sido estabelecidos com base nos textos, os fatores "Humanos - Psicológicos - Individuais Atenção", "Humanos - Psicológicos - Individuais - Processo Decisório". Esses fatores foram categorizados como "indeterminado", conforme indicado no relatório. 
No relatório do acidente PT-NEB, de uma aeronave modelo EMB 711 que colidiu com uma árvore e posteriormente contra o solo durante a aproximação para o pouso, não foram aprofundados os fatores humanos psicológicos, tendo sido estabelecidos, dessa forma, com base nos textos, os fatores "Humanos - Psicológicos - Individuais - Invulnerabilidade", "Humanos - Psicológicos - Individuais - Processo Decisório", e "Humanos - Psicológicos Individuais - Atitude". No entanto, categorizaram-se esses fatores como "indeterminado", conforme indicado no relatório. Nesse mesmo acidente, notou-se a indicação dos ferimentos causados pelo acidente como fator contribuinte para agrava-lo, pelo fato do piloto ter vindo a falecer por essa razão. No entanto, entende-se que essa condição médica é consequência do acidente, e não fator contribuinte do mesmo, não tendo sido, portanto, considerada.

\subsubsection{6 - EXPERIÊNCIA DO PILOTO}

A variável de experiência do piloto foi dividida em três tipos considerando, sempre, a experiência dos pilotos medida em quantidade de horas de voo. A primeira variável representa a "Quantidade de Horas Totais", ou seja, quantas horas de voo o piloto possui desde o início de sua carreira; a segunda representa a "Experiência recente", que trata da quantidade de horas de voo nos últimos 30 dias antes do acidente; e a terceira representa a "Quantidade de Horas no Modelo de Aeronave do Acidente", que é a experiência de voo no tipo de aeronave específico do acidente.

Consideraram-se apenas os valores de horas inteiras, desprezando-se os minutos. Nas situações em que não havia exatidão na quantidade de horas, indicando, por exemplo, "mais de X horas", sendo X a quantidade de horas, foi adotado o valor do qual se havia garantia, como foi, por exemplo, o caso do Relatório Final do PT-HSM, uma aeronave modelo 210M que perdeu partes em voo devido a condições meteorológicas adversas.

Nos casos em que existia presença de copiloto, foram somados os dados de horas do copiloto e do comandante. Esse foi o caso dos Relatórios de Acidente: PT-CTL, uma aeronave modelo V-35 que perdeu controle em voo devido a condições meteorológicas adversas; PT-VDA uma aeronave modelo EMB810-D que perdeu controle em voo durante a decolagem; N313PC uma aeronave de matrícula estrangeira de modelo PA-42-1000 que perdeu o controle em solo após o pouso; PT-AQO uma aeronave modelo Cessna 170 A com falha de motor em voo após uma arremetida; e PT-VHK uma aeronave modelo EMB 711 ST que colidiu em voo com a encosta de uma serra encoberta por nuvens após a decolagem (já mencionada anteriormente). No relatório desse último acidente (PT-VHK), as informações referentes à quantidade de horas dos pilotos estavam desatualizadas (comandante) ou não foram encontradas (copiloto). Sendo assim foi considerada a quantidade de horas totais desatualizadas do comandante tanto na "Quantidade de Horas Totais" quanto na "Quantidade de Horas no Modelo de Aeronave do Acidente", não se preenchendo a "Experiência recente". No relatório do PT-VLC, uma aeronave modelo EMB-810D que executou voo controlado para o terreno ${ }^{7}$, foi considerada a

\footnotetext{
${ }^{7}$ Conhecido por Controlled Flight Into Terrain (CFIT), trata-se de voo controlado para o solo com todos os seus sistemas e comandos funcionando em perfeitas condições. Costuma ocorrer por falha ativa do piloto.
} 
experiência na aeronave que foi identificada no Diário de Bordo durante o ano do acidente (2007) e o ano anterior, totalizando 111 horas.

É importante ressaltar que de todos os Relatórios analisados, 22 não continham os dados sobre a quantidade de horas, o que limita as análises com essas variáveis de experiência a uma amostra de 71 relatórios de acidentes, ou seja, $77 \%$ do total de relatórios disponíveis.

\subsubsection{7 - QUALIFICAÇÃO DO PILOTO}

Além da experiência do piloto, levantou-se a qualificação do Piloto quanto a possuir respectivamente "Licença de Piloto Privado", "Licença de Piloto Comercial", "Habilitação de Voo por Instrumentos (IFR)”, e "Curso Específico da Aeronave”, significando:

- Licença de Piloto Privado (PP): A licença de Piloto Privado é a primeira necessária para que o envolvido seja considerado Piloto. Ela é necessária para que se obtenham quaisquer umas das explicadas a seguir e não permite que seja exercida atividade remunerada.

- Licença de Piloto Comercial (PC): A licença de Piloto Comercial é o que garante o direito de exercer função remunerada, garantindo a profissionalização do piloto. Nos casos em que o piloto possuía habilitação PLA (Piloto de Linha Aérea), foi considerado como "PC", pelo fato de ser pré-requisito para a obtenção da carteira de "PLA".

- Habilitação de Voo por Instrumentos (IFR): Essa habilitação indica que o piloto está apto a voar em condições meteorológicas adversas, utilizando apenas os instrumentos de bordo. Apesar de também poder ser realizada por Piloto Privado, esse não foi o caso de nenhum dos pilotos analisados, tendo todos pelo menos a licença de Piloto Comercial.

- Curso Específico da Aeronave: Considerada aos pilotos que tenham realizado curso específico da aeronave, semelhante ao que é obrigatório para aeronaves que exigem a habilitação "Tipo". Não foi considerado como tal, habilitações MLTE (para aeronaves multimotoras), nem Anfíbio (como o caso do PT-ONN, aeronave modelo M-7-235 MAULE que perdeu o controle em voo após a decolagem na água), por se tratarem de habilitações que permitem aos pilotos operarem mais de um modelo de aeronave diferente. Todos os pilotos que possuíam algum tipo de curso específico, também possuíam acumuladas as licenças de PC e IFR.

Em casos como o do PT-RYC, aeronave modelo EMB-711ST que perdeu controle em voo e colidiu com uma serra logo após a decolagem, em que o piloto possuía a habilitação IFR, mesmo que vencida, considerou-se como IFR pelo fato do próprio Cenipa descrever que "o piloto não estava qualificado, mas, considerando as horas de voo registradas, possuía experiência suficiente para realizar o tipo de voo" (Brasil, 2015f, p. 8). 
No caso de acidentes com presença de copiloto, foram mantidos os dados de licença daquele que possuía maior quantidade de licenças, como foi o caso dos Relatórios de Acidente já mencionados anteriormente: PT-CTL, uma aeronave modelo V-35 que perdeu controle em voo devido a condições meteorológicas adversas; PT-VDA uma aeronave modelo EMB810-D que perdeu controle em voo durante a decolagem; N313PC uma aeronave de matrícula estrangeira de modelo PA-42-1000 que perdeu o controle em solo após o pouso; PT-AQO uma aeronave modelo Cessna 170A com falha de motor em voo após uma arremetida; e PTVHK uma aeronave modelo EMB 711 ST que colidiu em voo com a encosta de uma serra encoberta por nuvens após a decolagem.

Houve dois casos em que se tratava de acidentes com aeronaves utilizadas no transporte de paraquedistas. No acidente da aeronave PT-OQR, modelo C208 que colidiu com paraquedistas, o piloto estava com a habilitação de "piloto lançador de paraquedistas" vencida, enquanto que no acidente do PT-BXQ, uma falha de motor em voo de uma aeronave modelo Cessna $180 \mathrm{~F}$, o piloto possuía a habilitação válida. No entanto, essas particularidades não interferem nas análises do presente trabalho.

\subsubsection{8 - FATALIDADE}

Levantaram-se também os dados sobre a fatalidade dos acidentes, considerando a tripulação, os passageiros, e os terceiros. Se, por exemplo, apenas um passageiro faleceu em decorrência do acidente, mesmo que todos os outros tenham sobrevivido, o acidente foi considerado como fatal.

\subsubsection{9 - MOTORIZAÇÃO}

Considerando os Relatórios, buscaram-se no Registro Aeronáutico Brasileiro (RAB) informações quanto ao número de motores da aeronave de acordo com sua matrícula, tendo todos os acidentes analisados acontecido em aeronaves monomotoras ou bimotoras.

\subsubsection{0 - PRESENÇA DE COPILOTO}

Copiloto ou segundo piloto em comando é um piloto, membro da tripulação de uma aeronave, cuja função é auxiliar o piloto em comando durante a operação da aeronave. A presença de copiloto não é obrigatória na operação de aviões "classe" como os analisados nesse trabalho.

Foram encontrados apenas cinco relatórios com a presença de copiloto, todos citados anteriormente, sendo eles os acidentes: PT-CTL, uma aeronave modelo V-35 que perdeu controle em voo devido a condições meteorológicas adversas; PT-VDA uma aeronave modelo EMB810-D que perdeu controle em voo durante a decolagem; N313PC uma aeronave de matrícula estrangeira de modelo PA-42-1000 que perdeu o controle em solo após o pouso; PT-AQO uma aeronave modelo Cessna 170A com falha de motor em voo após uma 
arremetida; e PT-VHK uma aeronave modelo EMB 711 ST que colidiu em voo com a encosta de uma serra encoberta por nuvens após a decolagem.

\section{2 - TRATAMENTO ESTATÍSTICO}

O tratamento estatístico dos dados com instrumentos descritivos e analíticos foram realizados por meio do software IBM Statistical Package for Social Sciences (SPSS) (2010).

Para as análises que não contemplam a experiência do piloto, a amostra deste estudo é constituída por 93 relatórios de acidentes, enquanto que para as análises relacionadas à experiência dos pilotos, encontrou-se um número inferior de relatórios disponíveis devido ao fato de 22 dos relatórios não possuírem essas informações, sendo a amostra dessas análises, portanto, de 71 acidentes.

Para possibilitar as análises da experiência, foram agrupadas e codificadas as três variáveis de tempo relacionadas à experiência do piloto - experiência recente, experiência na aeronave do acidente e experiência total - por meio de uma análise da distribuição das mesmas na amostra disponível.

Escolheu-se dividir esses dados de experiência (em quantidade de horas de voo) em três classes conforme o Quadro 3.1, sendo elas "pouca experiência", "média experiência", "elevada experiência", agrupando-as levando em conta os percentis, neste caso $33 \%$ e 66\%, sem excluir os outliers.

Quadro 3.1 - Categorias de experiência (elaborado pelo autor).

\begin{tabular}{|c|c|c|}
\hline Experiência recente & $\begin{array}{c}\text { Experiência na aeronave } \\
\text { do acidente }\end{array}$ & Experiência total \\
\hline$<10 \mathrm{~h}=$ pouca experiência & $<100 \mathrm{~h}=$ pouca experiência & $\begin{array}{c}<1000 \mathrm{~h}=\text { pouca } \\
\text { experiência }\end{array}$ \\
\hline $\begin{array}{c}10 \mathrm{~h}-23 \mathrm{~h}=\text { média } \\
\text { experiência }\end{array}$ & $\begin{array}{c}100 \mathrm{~h}-356 \mathrm{~h}=\text { média } \\
\text { experiência }\end{array}$ & $\begin{array}{c}1000 \mathrm{~h}-4600=\text { média } \\
\text { experiência }\end{array}$ \\
\hline $23 \mathrm{~h}>=$ elevada experiência & $\begin{array}{c}356 \mathrm{~h}>=\text { elevada } \\
\text { experiência }\end{array}$ & $\begin{array}{c}4600 \mathrm{~h}>\text { elevada } \\
\text { experiência }\end{array}$ \\
\hline
\end{tabular}

É importante destacar que essas classes são válidas apenas para essa amostra, ou seja, dos acidentes da aviação geral no Brasil com relatórios disponíveis, não podendo ser consideradas representativas em outras categorias como aviação agrícola, instrução ou linha aérea regular, ou na aviação geral de países diferentes do Brasil, por exemplo.

Também foi realizada a análise de normalidade da amostra, para que se pudessem definir quais os testes estatísticos a serem aplicados com o objetivo de obter as correlações entre as variáveis quantitativas da base de dados. Optou-se por analisar todas as relações possíveis, considerando que se trata de uma base de dados relativamente pequena. 
Esse teste objetiva verificar se as variáveis quantitativas (tanto ordinal quanto scale) possuíam uma distribuição normal, para que se pudessem definir alguns dos testes estatísticos que poderiam ou não ser utilizados. Para tal, existem os testes de Shapiro-Wilk (para amostras inferiores a 30) e de Kolmogorov-Smirnov (que foi o utilizado no presente trabalho). No teste de Kolmogorov-Smirnov, o nível de significância deve ser superior a 0,05 para que se considerasse que os dados têm uma a distribuição normal, sendo que nesse teste, foi realizada a correção de Lilliefors. Ao se aplicar o teste Kolmogorov-Smirnov às variáveis quantitativas, verificou-se que as variáveis não possuem uma distribuição normal (Apêndice A1), o que direcionou esse estudo a usar testes não paramétricos, totalizando 36 análises.

Buscou-se utilizar alguns testes para medir a relação sempre entre duas variáveis, indicando a sua força e direção. Considerando isso, foi necessário escolher um coeficiente, sendo os mais comuns o Coeficiente de Pearson, usado quando as variáveis são quantitativas e têm uma distribuição normal e o Coeficiente de Spearman, usado quando as variáveis são ordinais ou quando não têm uma distribuição normal. Neste estudo, como os dados não estão em uma distribuição normal, utilizou-se o Coeficiente de Spearman, para as comparações entre as variáveis quantitativas: total de fatores contribuintes; total de fatores indeterminados; nível de qualificação dos pilotos; experiência (total, recente, e na aeronave do acidente).

As correlações que possuem interesse para o trabalho em questão são apresentadas da seguinte forma: RS [N] = "Correlation Coefficient", $p=$ Sig, sendo que se Sig < 0,05 significa que existe uma correlação estatisticamente significativa com um grau de confiança de $95 \%$. O valor do coeficiente de correlação (que pode ser negativo ou positivo) fornece o peso da correlação. Por exemplo, se RS $=0,442$ pode-se dizer que " $44,2 \%$ dos resultados podem ser explicados por esta correlação". Se o coeficiente é negativo, não se deve levar em conta o sinal, ou seja, se RS = - 0,530 considera-se o valor de 53,0\%, pois o sinal representa somente a orientação da reta da relação. Os resultados desses testes podem ser encontrados no Apêndice E, nas Figs. E.1, E.2 e E.3.

O coeficiente de Spearman foi utilizado para analisar as correlações entre várias variáveis entre si: total de fatores; total de fatores indeterminados; nível de qualificação dos pilotos; e experiência (total, recente, e na aeronave do acidente), totalizando 15 análises (Apêndice B).

O Teste U de Mann-Whitney é usado quando a distribuição das variáveis não é normal, em substituição do teste $T$-Student para amostras independentes e compara a média de variáveis ordinais e quantitativas entre dois grupos independentes, que neste caso foram as respostas do tipo, por exemplo: 0 - Não e 1 - Sim (variáveis dicotômicas). Pode-se concluir que existe diferença de entre os grupos se $\mathrm{p}<0,05$. Esse teste foi aplicado nas variáveis copiloto, fatalidade, e quantidade de motores, relacionando-as com: total de fatores; total de fatores indeterminados; nível de qualificação de pilotos; e as de experiência total, recente, e na aeronave do acidente, totalizando 18 análises (Apêndice $\mathrm{C}$ ).

$\mathrm{O}$ teste de independência do $\mathrm{X}^{2}$ (Qui-quadrado de Pearson) permite confirmar se duas variáveis nominais estão estatisticamente relacionadas, quando $\mathrm{p}<0,005$. O coeficiente de $\mathrm{X}^{2}$ 
é um valor de dispersão entre duas variáveis nominais, que indica em que medida os valores observados desviam do valor esperado, sendo que quanto maior o valor, maior é a relação entre as variáveis analisadas. Pela leitura da tabela de cruzamento de variáveis que o teste apresenta é possível verificar qual a variação de respostas obtida. Esse teste foi aplicado às três variáveis nominais, que também eram diatômicas: copiloto, fatalidades e motorização totalizando três análises (Apêndice D).

\section{4 - FLORESTA DE CAMINHOS ÓTIMOS (OPF)}

Para se conhecer os padrões de acidentes mais relevantes, foi aplicado um método indutivo de Aprendizado de Máquina, uma área da Inteligência Artificial (IA). A adoção desse método foi decidida por se tratar de uma análise complexa quanto à quantidade de variáveis, apesar do tamanho da amostra não ser considerado grande, por ser inferior a 100.

É importante esclarecer que a IA é um campo de estudo de agentes inteligentes, ou seja, um determinado sistema (nesse caso, um framework $^{8}$ ) percebe o ambiente e toma as devidas atitudes visando maximizar as chances de resultados de sucesso. A ferramenta baseada em Aprendizado de Máquina que foi utilizada é um classificador de padrões conhecido como Floresta de Caminhos Ótimos (Optimum-Path Forest - OPF). Nessa ferramenta, esses padrões são chamados de clusters de representatividade (Papa, 2008).

O algoritmo da ferramenta OPF foi proposto por Papa (2008) e tem base na IFT (Image Foresting Transform - Transformada-Imagem Floresta), criada por Falcão et al. (2004). O que diferencia o OPF da IFT é o fato do primeiro poder ser aplicado em diferentes tipos de conjuntos de dados, enquanto a aplicação da IFT se limita ao reconhecimento de padrões em imagens. A escolha do OPF se deu por ele ser um método de reconhecimento tanto eficiente quanto eficaz de padrões, inicialmente muito utilizado em análises de imagens, em que as amostras podem ser pixels, imagens ou objetos de imagens, como por exemplo, contornos ou regiões, e mais recentemente em outras aplicações.

Considerando essas outras aplicações do OPF, a ferramenta tem sido utilizada em diferentes áreas no meio acadêmico, como por exemplo, para reconhecimento de faces (Papa et al., 2009), detecção de intrusos em redes de computadores (Pereira et al., 2012), classificação de padrões de gêneros musicais (Marques et al., 2011), identificação de chuvas por meio de imagens de satélite (Papa et al., 2010), fraudes de perdas de energia por motivos não técnicos em companhias elétricas (Ramos et al., 2010, 2011), detecção de emoções por meio da fala (Iliev et al., 2010), detecção de patologias na laringe (Papa et al., 2008), e para classificar doenças (Pagnin, 2011).

Não se encontrou, no entanto, no início do desenvolvimento desse estudo, a sua aplicação a nenhuma área relacionada à aviação ou à segurança, o que tornou a aplicação do método neste

\footnotetext{
${ }^{8}$ Conjunto de códigos utilizados para resolver um problema de alguma área específica do conhecimento, compreendendo conjuntos de classes de alguma linguagem de programação específica, que podem ser utilizadas para auxiliar, por exemplo, no desenvolvimento de um software.
} 
trabalho uma análise exploratória, e de certa maneira, inovadora. Inicialmente, realizou-se uma pesquisa (Hespanhol et al., 2015) por meio da qual se verificou ser possível a aplicação do método, desde que fossem tomadas algumas precauções quanto à quantidade de possibilidades nas variáveis analisadas. Após essa aplicação do método e a análise dos seus resultados, verificou-se que análises do padrão de ocorrência de características isoladas ou de no máximo duas variáveis, permitiriam resultados mais robustos e consequentemente, análises de melhor qualidade.

Quanto à sua aplicação, o OPF tem sido muito utilizado para se encontrar padrões em diversos tipos de base de dados tanto de amostras quanto de populações, que podem estar totalmente rotuladas, parcialmente rotuladas ou não rotuladas. Essa rotulação define qual das três técnicas diferentes no OPF é utilizada, sendo elas: supervisionada (mais utilizada), semisupervisionada e não-supervisionada. As técnicas semi-supervisionada e supervisionada são utilizadas quando já se conhece o padrão que se busca encontrar, colocando o framework para aprender e reconhecer novos casos ou amostras quando os mesmos se relacionam com os rótulos da base de dados. No presente trabalho, foi utilizada a técnica não-supervisionada pelo fato de não desejar limitar os resultados e buscar saber quais são os possíveis padrões em cada uma das análises, ou seja, buscar-se-á analisar os seus resultados, que podem ser de classes diferentes que podem formar um mesmo cluster, ou uma classe dividida em vários clusters.

De acordo com de Souza et al. (2012), o algoritmo do OPF possui eficiência no processo de treinamento e eficácia na etapa de classificação dos dados. O autor ainda considera sua abordagem matemática como simples, explicando que a ferramenta fundamenta-se basicamente na Teoria dos Grafos ${ }^{9}$ e alguns algoritmos aplicados nesta Teoria, que são divididos em duas etapas, sendo elas, respectivamente: treinamento e testes.

De acordo com Souza et al. (2012), a ideia principal do método consiste em conectar as amostras analisadas como um grafo completo, para posteriormente buscar uma árvore geradora mínima, bem como os elementos mais representativos de cada classe do conjunto de treinamento, conhecidos como protótipos, que são os elementos de fronteiras entre cada classe. $\mathrm{O}$ autor ainda afirma que esses protótipos competem entre si, disputando as outras amostras por meio de ofertas de caminhos de menor custo ${ }^{10}$ e os rótulos que porventura possuam, para obterem um conjunto de treinamento particionado que gera uma coleção de árvores, que unidas são chamadas de floresta, dando nome ao classificador.

O OPF não-supervisionado permite que se encontre diferentes agrupamentos em um determinado conjunto de dados, sem que seja necessário definir a sua quantidade, encontrando os elementos mais significativos desses agrupamentos. De acordo com Afonso (2013), essa é uma das vantagens em relação a outras técnicas, "uma vez que o OPF nãosupervisionado pode encontrar melhores agrupamentos e em menor tempo quando comparado

\footnotetext{
${ }^{9}$ Ramo da matemática responsável pelas relações entre os rótulos de um determinado conjunto, por meio de estruturas chamadas grafos, que podem ser direcionados, orientados, dígrafos ou triviais (Feofiloff et al., 2011).

${ }^{10}$ Esse custo não se refere a vantagens financeiras, mas de vantagens relacionadas às semelhanças entre os relatórios, nos caso desse trabalho.
} 
à outras técnicas de agrupamento" (Afonso, 2013, p.4). O OPF não-supervisionado também possui uma etapa de treinamento, da mesma forma que a versão supervisionada. No entanto, o OPF não-supervisionado trabalha com conjuntos de amostras não rotuladas.

Esse método considera a distância entre as características, em que as amostras de dados são os nós de um grafo no espaço de características e os arcos são definidos por uma relação de adjacência. A minimização ou maximização de uma função de valor desses caminhos pelo algoritmo IFT emite uma floresta de caminhos ótimos, que é uma partição de dados em grupos ou classes. A formação consiste em encontrar protótipos e uma floresta de caminhos ótimos a partir de um determinado conjunto de treinamento. A classificação de uma nova amostra é feita considerando-a como parte do grafo original visando melhorar o caminho até ele. A amostra é então assumida como sendo do mesmo grupo ou turma da raiz que o conquistou por este caminho ideal.

Para compreender a lógica por traz do OPF, considerar-se-á como exemplo um conjunto de dados de acidentes representados em duas dimensões (2D) nas Figs. 3.8, 3.9 e 3.10, em que se encontraram os valores máximos relevantes sobre experiência dos pilotos, nas regiões mais brilhantes, sendo eles as amostras "A" e "B", podendo "A" ser "alta experiência" e "B" "baixa experiência", por exemplo. Considerando esses valores máximos, objetiva-se classificar as outras amostras do conjunto de dados e para exemplificar, selecionou-se a amostra " $C$ " na Fig. 3.8, que deverá ser alcançada por um caminho cujo valor mínimo de distância (considerando a similaridade com as máximas, deverá se aproximar de "A" ou "B" de acordo com a experiência do piloto). O OPF modela esse problema de reconhecimento de padrões por meio de um algoritmo de agrupamento baseado em um grafo em que as amostras são os nós e os arcos acabam por ser definidos por relação de adjacência.

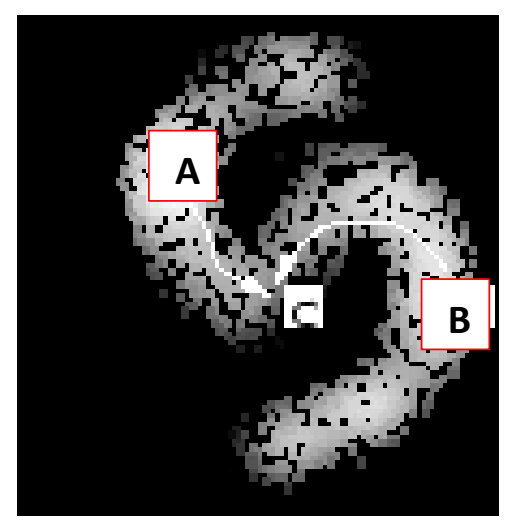

Figura 3.8 - Conjunto inicial de dados em 2D (Modificado - Rocha, 2009).

A partir disso, inicia-se o processo de competição entre as máximas ("A" e "B"), que oferecem caminhos de custo ótimo para todas as amostras da base de dados. Dessa forma, qualquer uma dessas máximas pode ser considerada representativa, e com isso conseguir alcançar outras amostras.

A Fig. 3.9 mostra uma situação posterior, considerando poucos caminhos disponibilizados, ou pouca força de conexão entre as amostras, resultando em quatro agrupamentos distintos, que 
poderiam ser quatros níveis diferentes de experiência - variando entre "alta", "média", "baixa" e "muito baixa", por exemplo - e não mais apenas duas máximas "A" e "B".

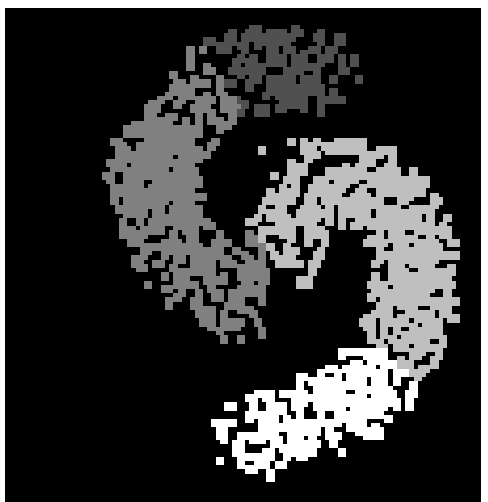

Figura 3.9 - Conjunto de dados em processamento em 2D (Rocha, 2009).

A Fig. 3.10 mostra uma situação de mais caminhos fornecidos, ou seja, mais possibilidades de conexão entre as amostras, ou maior força de conectividade entre as amostras, o que acaba por resultar em apenas dois agrupamentos. A Fig. 3.10 representa a maximização da função de conectividade de cada amostra, de maneira independente do seu nó de partida, dividindo o grafo no que é chamado floresta de caminhos ótimos, em que cada raiz (ou amostra mais representativa) define uma árvore de caminho ótimo (cluster) composta por amostras com maior poder de ligação entre elas. Essas amostras mais representativas são os "padrões" foco das análises do presente trabalho, que ser.

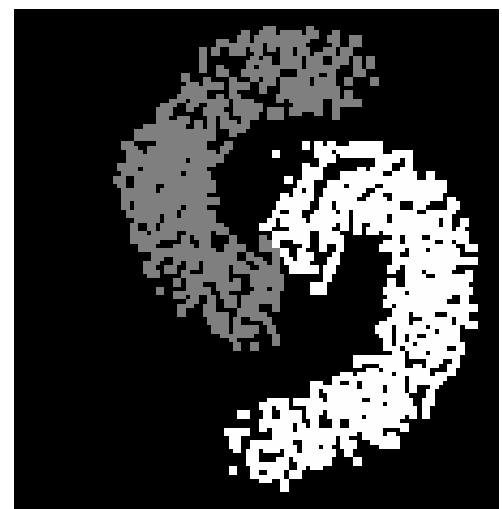

Figura 3.10 - Conjunto de dados processados em 2D (Rocha, 2009).

De maneira geral, o OPF não-supervisionado classifica primeiro uma amostra em uma das classes de amostras mais relevantes e, em seguida, define a zona de influência e robustez dessa amostra sobre as demais.

Nesse trabalho, foi utilizada a versão 2.1, mais recente disponível entre maio e outubro de 2015. Essa versão do framework, bem como o seu código fonte estão disponíveis desde junho de 2014 no website do LibOPF do Instituto de Computação da Unicamp (Unicamp, 2015). O LibOPF é uma biblioteca de funções e programas de uso livre dos classificadores OPF. De acordo com o website do LibOPF (Papa et al, 2008), essa segunda versão possui 
características adicionais à primeira tanto no framework supervisionado quanto na versão nãosupervisionada, que foi a utilizada no presente estudo.

Para as análises desse trabalho, foram consideradas cinco opções de caminhos, visando medir a conectividade entre as amostras, sendo elas: 1, 25, 50, 75 e 100 caminhos. A intenção é buscar os padrões e verificar se o OPF é capaz de relacioná-las segundo as suas classes, para confirmar características específicas de cada classe. Espera-se obter uma quantidade maior de resultados quanto menor for a quantidade de caminhos ( 1 e 25 , por exemplo), e os principais padrões representados conforme se aumente a quantidade de caminhos (75 ou 100, por exemplo). Apesar disso, sabe-se que esses resultados podem oscilar conforme a força de atratividade de cada amostra.

Apesar das vantagens do método, tem-se como limitação o fato de no OPF não poderem ser inseridos dados nulos relacionados aos acidentes. Portanto, os 22 relatórios em que faltavam dados correspondentes à experiência do piloto (em quantidade de horas de voo), não foram incluídos na análise, restando 71 relatórios que foram analisados e classificados no OPF.

\section{4 - RESULTADOS E ANÁLISES}

Foram conduzidas 49 análises de resultados com o método OPF nos relatórios disponíveis, sendo que 22 desses resultados foram robustos o suficiente para serem analisados e 27 não tiveram resultados satisfatórios considerando o âmbito do presente trabalho.

Para melhor compreender as análises realizadas: inicia-se demonstrando e analisando os resultados em que se obteve robustez na aplicação do método de Floresta de Caminhos Ótimos e as observações sobre os resultados estatísticos das análises; seguido por análises sobre possíveis melhorias na utilização do método e da ferramenta, também os comparando com os resultados estatísticos das análises; e por fim, são realizadas análises complementares considerando o que foi verificado nos relatórios de acidentes analisados durante a extração dos dados que compuseram o banco de dados analisado no método do OPF. A organização dos resultados pode ser compreendida por meio do mapa mental da Fig. 4.1. 


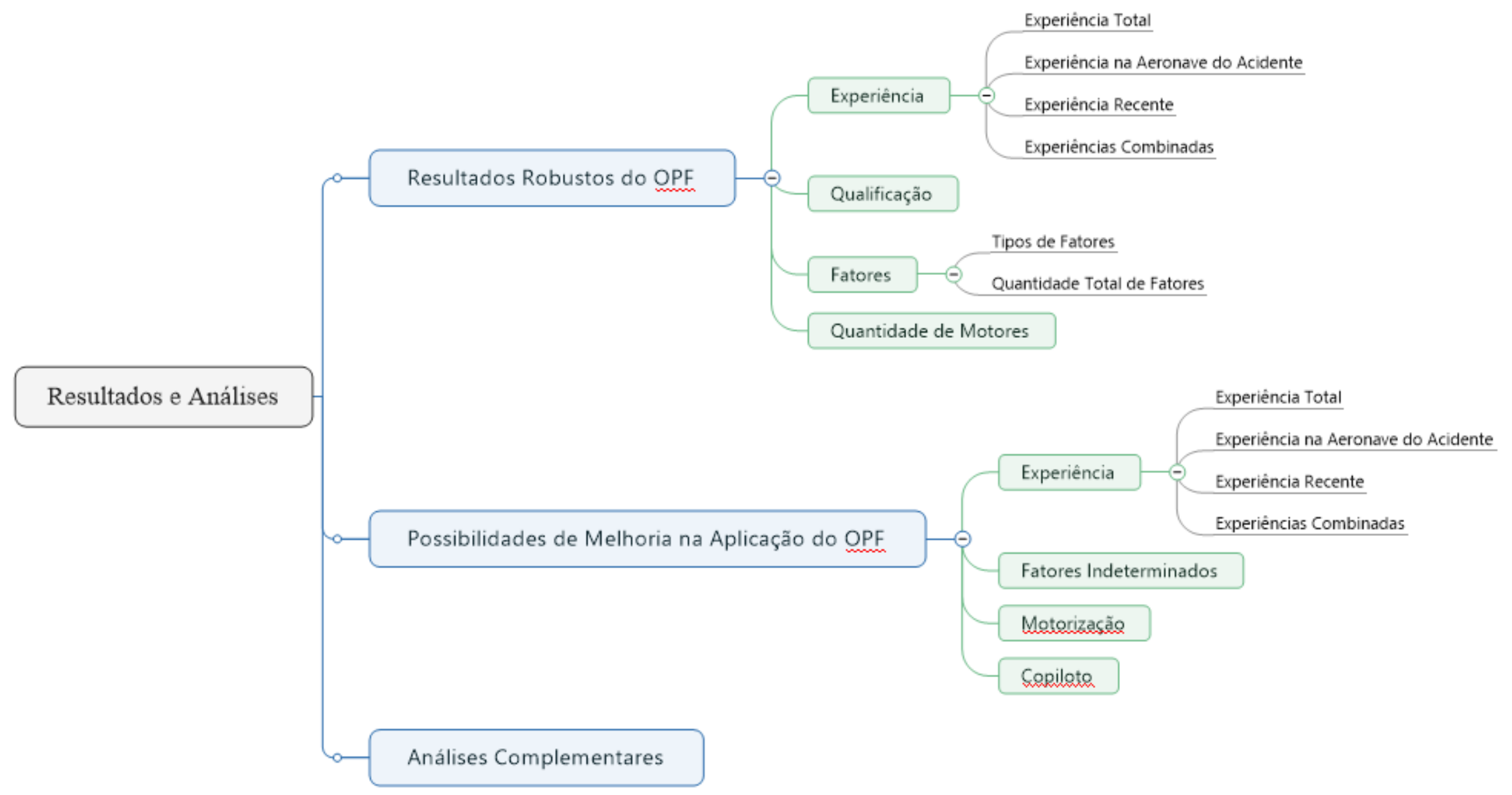

Figura 4.1 - Mapa mental dos resultados e análises (elaborada pelo autor) 


\section{1 - RESULTADOS ROBUSTOS DO OPF}

\subsection{1 - EXPERIÊNCIA}

\subsubsection{1 - EXPERIÊNCIA TOTAL}

Analisando a experiência total e sua relação com a fatalidade, não se encontrou relação por meio da estatística, em que se utilizou o teste $U$ de Mann Whitney. No entanto, no OPF obtiveram-se, com um, 25 e 50 caminhos, dois padrões, sendo um com média experiência total sem fatalidades, e outro com baixa experiência total com fatalidade. Quando se fornecem 75 e 100 caminhos, o padrão que se mantém é o de média experiência total sem fatalidade.

Isso significa que a experiência total foi confirmada como tendo influência sobre a fatalidade de um acidente, pois baixa experiência total está relacionada à fatalidade enquanto que média experiência total já mostra um padrão de acidentes sem fatalidades. Um bom indicativo do panorama da aviação geral brasileira é que apesar da baixa experiência aparecer como padrão, conforme se aumentam os caminhos, o padrão que se mostra mais representativo dessa amostra é de acidentes sem vítimas fatais - com pilotos de média experiência total.

Considerando os tipos de fatores, por se tratar de 57 possibilidades de variáveis, não se utilizou análise estatística. Com o OPF, não se teve robustez para análise com um caminho, no entanto, com 25 e 50 caminhos, são mostrados três padrões distintos - portanto, não analisáveis - para pilotos de elevada experiência total e um padrão para pilotos com baixa experiência total, demonstrado no Quadro 4.1, enquanto que se aumentando a quantidade de caminhos para 75 e 100, o padrão que se revela mais representativo é de pilotos de média experiência total com o único fator, sendo esse fator o "esquecimento", conforme possível verificar no Quadro 4.2. 
Quadro 4.1 - Padrões para nível baixo de experiência total com 25 caminhos (elaborado pelo autor).

\begin{tabular}{|l|l|}
\hline \multicolumn{2}{|c|}{ Baixa (25 caminhos) } \\
\hline \multirow{4}{*}{ Humano - Operacional } & Julgamento de pilotagem \\
\cline { 2 - 2 } & Planejamento gerencial \\
\cline { 2 - 2 } & Pouca experiência do piloto \\
\cline { 2 - 2 } & Indisciplina de voo* \\
\cline { 2 - 2 } & Aplicação de comandos* \\
\hline \multirow{4}{*}{ Humano - Psicológico - Individual } & Condições Meteorológicas Adversas* \\
\hline \multirow{3}{*}{ Humano - Psicológico - Psicossocial } & Atitude \\
\cline { 2 - 2 } & Motivação \\
\cline { 2 - 2 } & Processo Decisório* \\
\hline * Fatores Indeterminados & Dinâmica de Equipe \\
\cline { 2 - 2 } & Formação, Capacidade e Treinamento \\
\cline { 2 - 2 } & Relações Interpessoais* \\
\hline
\end{tabular}

É importante ressaltar que no Quadro 4.1 constam também os fatores indeterminados, que só aparecem no padrão referente à baixa experiência total (com 25 caminhos).

Quadro 4.2 - Padrão para nível médio de experiência total com 75 e 100 caminhos (elaborado pelo autor).

\begin{tabular}{|l|l|}
\hline & \multicolumn{2}{c|}{ Média (75 e 100 caminhos) } \\
\hline Humano - Operacional & Esquecimento \\
\hline
\end{tabular}

Quando se analisa a experiência total e sua relação com a quantidade total de fatores por meio da estatística, utilizando Spearman, não se obtém resultados robustos, o que também acontece com apenas um caminho no OPF. Entretanto, tanto com 25 quanto 50 caminhos, têm-se como padrão pilotos com elevada experiência total e três fatores contribuintes, e com 75 e 100 caminhos, têm-se média experiência total e apenas um fator contribuinte.

Esse resultado sobre a quantidade total de fatores contribuintes não permite maiores conclusões senão que quanto maior a experiência total do piloto, maior a quantidade total de fatores para a ocorrência de um acidente - o que pode ser um indício de complemento à Teoria de Reason, considerando a aviação geral.

\subsubsection{2 - EXPERIÊNCIA NA AERONAVE DO ACIDENTE}

Utilizando o teste $U$ de Mann Whitney para analisar a relação entre a experiência na aeronave do acidente e a fatalidade, não se obteve resultados robustos que permitissem análise. No 
entanto, a relação entre essas duas características se mostrou tão forte que o resultado do OPF com um, 25 e 50 caminhos foi de pilotos com elevada experiência na aeronave do acidente e sem fatalidades, enquanto que pilotos com baixa experiência na aeronave possuem grande ligação com fatalidades nos acidentes. Um resultado tranquilizador, no entanto, é que, considerando os acidentes estudados, com 75 e 100 caminhos verificou-se que o padrão mais representativo de acidente é aquele em que se possui piloto altamente experiente na aeronave sem fatalidades no acidente.

Isso significa que a experiência na aeronave do acidente mostra resultados relevantes e que podem servir de embasamento para recomendações aos envolvidos com a filosofia Sipaer (Anac, Cenipa, proprietários de aeronaves e pilotos), pois ao notar-se que pilotos com maior experiência na aeronave possuem menos fatalidades como sendo um padrão, enquanto que pilotos menos experientes na aeronave costumam possuir maior fatalidade nos acidentes, deve-se buscar fortalecer a experiência na aeronave específica operada pelo piloto.

Quanto ao tipo de fatores e a experiência na aeronave do acidente, considerando o grande número de variáveis (57), não se utilizou estatística para analisar tal correlação. Com um caminho, os resultados do OPF não permitiram análise, no entanto, com 25 caminhos, a ferramenta indicou dois padrões para baixa experiência na aeronave (Quadro 4.3), e um padrão tanto para média experiência na aeronave (Quadro 4.4) quanto para elevada experiência na aeronave (Quadro 4.5).

Quadro 4.3 - Padrões dos tipos de fatores para baixa experiência na aeronave do acidente com 25 caminhos (elaborado pelo autor).

\begin{tabular}{|l|l|l|}
\hline \multicolumn{2}{|c|}{ Baixa } \\
\hline Padrão 1 & Humano - Operacional & Supervisão Gerencial (outros) \\
\hline \multirow{4}{*}{ Padrão 2 } & \multirow{4}{*}{ Humano - Operacional } & Supervisão Gerencial (outros) \\
\cline { 3 - 3 } & & Planejamento Gerencial \\
\cline { 3 - 3 } & \multirow{4}{*}{ Humano - Psicológico - Individual } & Instrução (outros) \\
\cline { 3 - 3 } & & Regulação \\
\cline { 3 - 3 } & & Pessoal de Apoio \\
\cline { 3 - 3 } & & Manutenção da Aeronave \\
\cline { 3 - 3 } & \multirow{2}{*}{ Humano - Psicológico - Organizacionais } & Percepção (outros) \\
\cline { 3 - 3 } & & Passividade \\
\cline { 3 - 3 } & & Hábito Adquirido (outros) \\
\hline
\end{tabular}


Quadro 4.4 - Padrão dos tipos de fatores para média experiência na aeronave do acidente com 25 caminhos (elaborado pelo autor).

\begin{tabular}{|c|c|c|}
\hline \multicolumn{3}{|c|}{ Média } \\
\hline \multirow{12}{*}{ Padrão 1} & \multirow{6}{*}{ Humano - Operacional } & Julgamento de Pilotagem \\
\hline & & Aplicação de Comandos* \\
\hline & & Condições Meteorológicas Adversas* \\
\hline & & Indisciplina de voo* \\
\hline & & Planejamento Gerencial \\
\hline & & Pouca Experiência do Piloto \\
\hline & \multirow{3}{*}{ Humano - Psicológico - Individual } & Atitude \\
\hline & & Processo Decisório* \\
\hline & & Motivação \\
\hline & \multirow{2}{*}{ Humano - Psicológico - Psicossocial } & Relações Interpessoais* \\
\hline & & Dinâmica de Equipe \\
\hline & $\begin{array}{l}\text { Humano - Psicológico - } \\
\text { Organizacionais }\end{array}$ & Formação, Capacidade e Treinamento \\
\hline
\end{tabular}

É importante ressaltar que no Quadro 4.4 constam também os fatores indeterminados.

Quadro 4.5 - Padrão dos tipos de fatores para elevada experiência na aeronave do acidente com 25 caminhos (elaborado pelo autor).

\begin{tabular}{|l|l|l|}
\hline \multicolumn{2}{|c|}{ Elevada } \\
\hline \multirow{4}{*}{ Padrão 1} & Humano - Operacional & Julgamento de Pilotagem \\
\cline { 3 - 3 } & \multirow{2}{*}{ Humano - Psicológico - Individual } & Supervisão Gerencial \\
\cline { 2 - 3 } & & Atenção \\
\cline { 2 - 3 } & Humano - Psicológico - Psicossocial & Atitude \\
\cline { 2 - 3 } & \multirow{2}{*}{ Humano - Psicológico - Organizacionais } & Processo Decisório \\
\cline { 2 - 3 } & & Comunicação \\
\cline { 2 - 3 } & & Clima Organizacional \\
\cline { 2 - 3 } & & Organização do Trabalho \\
\hline
\end{tabular}

Conforme se aumentou a quantidade de caminhos, no entanto, os padrões mais representativos diminuíram, sendo que com 50 caminhos, o padrão de experiência média na aeronave do acidente deixa de ser representativo, e com 75 e 100 caminhos, o padrão de elevada experiência na aeronave do acidente se torna o mais representativo de toda a população de dados analisada. 
Buscando relacionar a experiência na aeronave do acidente com a quantidade total de fatores por meio da estatística, utilizou-se o coeficiente de Spearman, que não permitiu maiores análises, da mesma forma que com um caminho no OPF. No entanto, com 25 e 50 caminhos, são indicados como padrão, pilotos com baixa experiência na aeronave do acidente com três fatores contribuintes, e com 75 e 100 caminhos, são indicados pilotos com elevada experiência na aeronave do acidente e apenas um fator contribuinte. Isso significa que quanto mais experiência na aeronave, menor a quantidade total de fatores contribuintes, que complementa a Teoria de Reason na população escolhida ressaltando que a quantidade de falhas latentes pode ser diminuída quanto maior for a experiência na aeronave específica.

\subsubsection{3 - EXPERIÊNCIA RECENTE}

Como em todas as análises dos tipos de fatores, nessa também não se realizou análise estatística devido à grande quantidade de variáveis (57). Com um caminho, os resultados também não permitiram análise, já com 25 caminhos, nota-se um padrão tanto para pilotos com elevada experiência recente (Quadro 4.6) quanto com baixa experiência recente (Quadro 4.8), e dois padrões para pilotos com média experiência recente (Quadro 4.7).

Quadro 4.6 - Padrão dos tipos de fatores para elevada experiência recente com 25 caminhos (elaborado pelo autor).

\begin{tabular}{|l|l|l|}
\hline \multicolumn{2}{|c|}{ Elevada } \\
\hline \multirow{4}{*}{\multicolumn{1}{|c|}{ Humano - Operacional }} & Julgamento de Pilotagem \\
\cline { 2 - 3 } Padrão 1 & \multirow{3}{*}{ Humano - Psicológico - Individual } & Supervisão Gerencial \\
\cline { 2 - 3 } & \multirow{3}{*}{ Humano - Psicológico - Psicossocial } & Atenção \\
\cline { 2 - 3 } & & Atitude \\
\cline { 2 - 3 } & Humano - Psicológico - Organizacional & Comunicação \\
\cline { 2 - 3 } & & Cultura do grupo de trabalho \\
\cline { 2 - 3 } & Cultura organizacional \\
\cline { 2 - 3 } & Clima Organizacional* \\
\hline * Fatores Indeterminados & Organização do Trabalho* \\
\hline
\end{tabular}


Quadro 4.7 - Padrões dos tipos de fatores para média experiência recente com 25 caminhos (elaborado pelo autor).

\begin{tabular}{|c|c|c|}
\hline \multicolumn{3}{|c|}{ Média } \\
\hline \multirow{2}{*}{ Padrão 1} & \multirow{2}{*}{ Humano - Operacional } & Supervisão Gerencial (outros) \\
\hline & & Manutenção da Aeronave \\
\hline \multirow{10}{*}{ Padrão 2} & \multirow{5}{*}{ Humano - Operacional } & Supervisão Gerencial (outros) \\
\hline & & Planejamento Gerencial \\
\hline & & Instrução (outros) \\
\hline & & Regulação \\
\hline & & Pessoal de Apoio \\
\hline & \multirow{4}{*}{ Psicológico - Individual } & Percepção (outros) \\
\hline & & Complacência \\
\hline & & Passividade \\
\hline & & Hábito Adquirido (outros) \\
\hline & Psicológico - Organizacionais & Cultura Organizacional \\
\hline
\end{tabular}

Quadro 4.8 - Padrão dos tipos de fatores para baixa experiência recente com 25 caminhos (elaborado pelo autor).

\begin{tabular}{|c|c|c|}
\hline \multicolumn{3}{|c|}{ Baixa } \\
\hline \multirow{12}{*}{ Padrão 1} & \multirow{6}{*}{ Humano - Operacional } & Julgamento de Pilotagem \\
\hline & & Aplicação de comandos* \\
\hline & & Condições Meteorológicas Adversas* \\
\hline & & Indisciplina de voo* \\
\hline & & Planejamento gerencial \\
\hline & & Pouca Experiência do piloto \\
\hline & \multirow{3}{*}{ Humano - Psicológico - Individual } & Atitude \\
\hline & & Processo Decisório* \\
\hline & & Motivação \\
\hline & \multirow{3}{*}{ Humano - Psicológico - Psicossocial } & Relações Interpessoais* \\
\hline & & Dinâmica de Equipe \\
\hline & & Formação, Capacidade e Treinamento \\
\hline
\end{tabular}

Conforme se aumenta para 50 caminhos, nota-se o padrão de pilotos com baixa experiência recente se dissolver entre os outros e se manterem os dois padrões de média experiência recente e o padrão de elevada experiência recente. Quando se aumenta o número de caminhos 
para 75 e 100, o único padrão que se mantém como mais representativo é de média experiência recente, mas que é diferente dos dois demonstrados no Quadro 4.7 (com 25 caminhos), possuindo este padrão apenas um fator contribuinte, sendo ele o esquecimento do piloto.

Apesar do resultado robusto com o método OPF, notou-se que essa informação possui pouco valor no sentido de prevenir novos acidentes, por acabar sendo representado pela experiência recente média. Isso pode ser resultado inclusive do limitado tempo analisado (últimos 30 dias antes do acidente), que podem variar muito em um mesmo piloto dependendo do mês ou até mesmo ano do acidente, visto que na aviação executiva, as aeronaves não são utilizadas em sua capacidade máxima como ocorre na aviação regular, ficando paradas por meses, em alguns casos.

\subsubsection{4 - EXPERIÊNCIAS COMBINADAS}

Inicialmente, foram relacionadas as três variáveis de experiência com os níveis de qualificação, sendo elas a experiência total do piloto, a experiência recente do piloto e a experiência do piloto na aeronave do acidente. Para essas três análises, utilizou-se o coeficiente de correlação de Spearman, que apresentou resultado positivo ao se analisar a experiência total, não apresentando correlação em nenhum dos outros dois casos (experiência recente e experiência na aeronave do acidente).

A análise da experiência total teve resultado positivo utilizando Spearman, sendo que o nível de qualificação dos pilotos tem uma relação positiva com o número total de horas de experiência $(R S[71]=0,281, p=0,018)$, que significa que quanto maior a qualificação de um piloto, maior o número total de horas de experiência, o que já era esperado. Utilizando o OPF para analisar a experiência total do piloto quanto ao seu nível de qualificação, com um caminho não se encontrou resultado que permitisse análise, mas com 25 caminhos, tem-se como padrão o nível alto de qualificação ("Tipo") para pilotos com média experiência total, e qualificação baixa ("Piloto Privado") para pilotos com baixa experiência. No entanto, encontrou-se como padrão mais representativo (com 50, 75 e 100 caminhos) o de pilotos altamente qualificados ("Tipo") com média experiência total.

O resultado da análise do OPF quanto ao nível de qualificação e a experiência na aeronave do acidente - sem resultado utilizando Spearman - indica alta similaridade entre os protótipos, pois com um caminho já se teve como padrão pilotos altamente qualificados ("Tipo") e de elevada experiência na aeronave do acidente, pilotos de média qualificação ("PC IFR") e de média experiência na aeronave do acidente, e pilotos de baixa qualificação ("PP") e baixa experiência na aeronave do acidente. Conforme se aumenta o número de caminhos (para 25, 50, 75 e 100), o padrão que se manteve foi de pilotos altamente qualificados e de elevada experiência na aeronave do acidente.

Analisando a experiência recente e o nível de qualificação - sem resultado utilizando Spearman - com o OPF, tem-se com um caminho o padrão de baixa experiência recente para 
pilotos com baixa qualificação ("PP"), elevada experiência recente para pilotos de nível médio de qualificação ("PC") e média experiência recente para pilotos de alto nível de qualificação ("Tipo"). Quando se aumentou o número de caminhos para 25, não se encontrou qualquer resultado que permita análise, mas conforme se aumentou o número de caminhos para 50, 75 e 100 caminhos, teve-se como padrão mais representativo o de pilotos de alto nível de qualificação ("Tipo”) e média experiência recente.

\subsection{2 - QUALIFICAÇÃO}

Utilizando o teste $U$ de Mann Whitney para se relacionar o nível de qualificação e a fatalidade nos acidentes não se encontrou resultados que permitissem análise. No entanto o OPF encontrou relação para a fatalidade para os níveis "Piloto Comercial IFR" (com 25 caminhos) e "Piloto Privado" (com 50 caminhos), sendo este padrão a ocorrência de falecimentos, enquanto que para o nível de qualificação mais alto ("Tipo") o padrão é de nenhum falecimento independente da quantidade de caminhos (um, 25, 50, 75 e 100).

Esses resultados significam que, considerando a qualificação dos pilotos e a sua relação com a fatalidade, percebeu-se que os extremos possuem relação, ou seja, quanto menor a qualificação (apenas "Piloto Privado"), maior a probabilidade do mesmo ser fatal, enquanto que quanto mais qualificados os pilotos ("Tipo"), menor a probabilidade de o acidente ser fatal.

Quanto à correlação com os tipos de fatores, que não foram analisados estatisticamente (57 variáveis), o OPF não apresentou resultados robustos para um, 25 e 50 caminhos, mas encontrou um padrão com 75 caminhos para o nível "Piloto Privado" (Quadro 4.9) e dois padrões para o nível “Tipo”, sendo um deles com 75 caminhos (Quadro 4.10) e outro com 100 caminhos (Quadro 4.11).

Quadro 4.9 - Padrão dos tipos de fatores para qualificação "Piloto Privado" com 75 caminhos (elaborado pelo autor).

\begin{tabular}{|l|l|}
\hline \multicolumn{2}{|c|}{ Piloto Privado (75 caminhos) } \\
\hline Humano - Operacional & Julgamento de Pilotagem \\
\hline
\end{tabular}


Quadro 4.10 - Padrão dos tipos de fatores para qualificação "Tipo" com 75 caminhos (elaborado pelo autor).

\begin{tabular}{|l|l|}
\hline \multicolumn{2}{|c|}{ TIPO (75 Caminhos) } \\
\hline \multirow{4}{*}{ Humano - Operacional } & Supervisão Gerencial \\
\cline { 2 - 2 } & Planejamento Gerencial \\
\cline { 2 - 2 } & Instrução \\
\cline { 2 - 2 } & Regulação \\
\cline { 2 - 2 } & Pessoal de Apoio \\
\hline \multirow{4}{*}{ Humano - Psicológico - Individual } & Percepção (não ligada ao piloto) \\
\cline { 2 - 3 } & Complacência \\
\cline { 2 - 3 } & Passividade (não ligada ao piloto), \\
\cline { 2 - 2 } & Hábito Adquirido \\
\hline Humano - Psicológico - Organizacional & Cultura Organizacional. \\
\hline
\end{tabular}

Quadro 4.11 - Padrão dos tipos de fatores para qualificação "Tipo" com 100 caminhos (elaborado pelo autor).

\begin{tabular}{|l|l|}
\hline & TIPO (100 Caminhos) \\
\hline Humano - Operacional & Esquecimento do piloto \\
\hline
\end{tabular}

Para se relacionar a quantidade total de fatores com o nível de qualificação, utilizou-se Spearman, sem resultados possíveis de serem analisados (da mesma forma que com um caminho o OPF). Com 25, 50 e 75 caminhos, o padrão de qualificação encontrado foi de "Piloto Comercial" com três fatores contribuintes por acidente, e com 100 caminhos o padrão encontrado foi de qualificação "Piloto Comercial IFR TIPO" e apenas um fator contribuinte nos relatórios finais. Esse foi um resultado relevante considerando a qualificação, pois significa que quanto maior a qualificação do piloto, menos fatores contribuintes acontecem, ou seja, o número de falhas latentes necessárias para um acidente é menor, o que torna a falha ativa como grande diferencial entre acontecer um acidente ou não quando em comparação com qualificações de níveis menores (como "Piloto Privado", por exemplo).

Considerando todas as análises em que se encontrou resultado robusto utilizando o OPF quanto ao nível de qualificação dos pilotos, a única variável que teve resultado positivo quanto à estatística, foi a presença de copiloto, em que se utilizou o teste $U$ de Mann Whitney. Nesse teste, encontrou-se que o nível de qualificação dos pilotos e a presença de copiloto possui $\mathrm{p}=0,035$, o que permite concluir, pela tabela Rank, que acidentes com presença de copiloto costumam ter maior nível de qualificação do piloto. No entanto, é importante destacar que na população estudada existiam apenas cinco relatórios de acidentes em que o copiloto estava presente. Para a análise do nível de qualificação e a presença de copiloto com o OPF, não se teve resultados com um, 50, 75 e 100 caminhos. O único resultado que se teve 
ocorreu com 25 caminhos, em que se teve como padrão o nível de qualificação média (PC) para os acidentes com copiloto, e nível de qualificação baixa (PP) para os acidentes sem copiloto, que vão ao encontro das conclusões que se teve com a análise estatística.

Ainda sobre essa relação de presença de copiloto e nível de qualificação, considerando que nas categorias de aeronaves estudadas a sua presença não é obrigatória, pode-se concluir que esses resultados representam o perfil de proprietário de aeronave quanto ao nível de preocupação e exigência referente à tripulação, sendo esse perfil de proprietários que preferem pilotos com maior nível de qualificação e com a presença de um copiloto, muito provavelmente por se preocuparem mais com a segurança de seus voos.

\subsection{3 - FATORES}

\subsubsection{1 - TIPOS DE FATORES}

Para as duas análises relacionadas aos tipos de fatores, não se utilizou nenhuma teoria estatística devido ao fato de serem muitas as possibilidades dentro da categoria (57 ao todo). As duas análises realizadas foram: dos tipos de fatores contribuintes isolados, a fim de verificar se existiu padrão na ocorrência dos mesmos, independente de outras variáveis; e dos fatores contribuintes e as fatalidades nos acidentes, para ver se existiu um padrão de ocorrência dos tipos de fatores que possa ser considerado como mais fatal e outro padrão de ocorrência dos tipos de fatores que seja menos fatal.

Quanto aos fatores contribuintes isolados para análise do OPF, não se obteve resultados com um, 25 e 50 caminhos, mas quando se aumentou a quantidade de caminhos para 75 e 100 caminhos, percebeu-se que o padrão foi representado por um acidente com apenas um fator contribuinte, sendo esse fator o "esquecimento".

Por meio do OPF, não se encontraram resultados robustos com um, 25 e 50 caminhos, mas encontraram-se dois padrões em relação à fatalidade com os tipos de fatores contribuintes ao se fornecer 75 caminhos. Um padrão representou os tipos de fatores que ocorreram em acidentes com vítimas fatais e outro os acidentes sem vítimas fatais, possíveis de serem visualizados no Quadro 4.12. 
Quadro 4.12 - Padrões dos tipos de fatores em relação à fatalidade do acidente com 75 caminhos (elaborado pelo autor).

\begin{tabular}{|c|c|}
\hline Com Fatalidade & Sem Fatalidade \\
\hline Humano - Operacional - Supervisão Gerencial & \multirow{10}{*}{$\begin{array}{l}\text { Humano - } \\
\text { Operacional - } \\
\text { Julgamento de } \\
\text { Pilotagem }\end{array}$} \\
\hline Humano - Operacional - Planejamento Gerencial & \\
\hline Humano - Operacional - Instrução & \\
\hline Humano - Operacional - Regulação & \\
\hline Humano - Operacional - Pessoal de Apoio & \\
\hline $\begin{array}{l}\text { Humano - Psicológico - Individual - Percepção (não ligada ao } \\
\text { piloto) }\end{array}$ & \\
\hline Humano - Psicológico - Individual - Complacência & \\
\hline $\begin{array}{l}\text { Humano - Psicológico - Individual - Passividade (não ligada ao } \\
\text { piloto) }\end{array}$ & \\
\hline Humano - Psicológico - Individual - Hábito Adquirido & \\
\hline Humano - Psicológico - Organizacional - Cultura Organizacional & \\
\hline
\end{tabular}

Ao se aumentar o número de caminhos para 100, verificou-se um padrão diferente como sendo o mais representativo: o de acidente sem vítimas fatais, em que apenas o fator contribuinte "esquecimento do piloto" influenciou.

\subsubsection{2 - QUANTIDADE TOTAL DE FATORES}

Ao se analisar a quantidade total de fatores contribuintes e a fatalidade da população, obtevese resultado estatístico significativo $(\mathrm{p}=0,001)$ ao se aplicar o teste $U$ de Mann Whitney, pois ao se analisar a tabela Rank, verificou-se que a quantidade total de fatores é superior nos acidentes com vítimas fatais.

Quando se analisou a quantidade total de fatores e a fatalidade no OPF, com apenas um caminho têm-se muitos padrões demonstrados (totalizando 12), sendo possível notar que os acidentes com vítimas fatais possuem uma grande quantidade total de fatores contribuintes, enquanto que acidentes sem vítimas fatais são extremos - possuem quantidade muito grande ou muito pequena de fatores contribuintes. Com 25, 50, 75 e 100 caminhos - que denota maior robustez ao padrão - têm-se como padrão os acidentes sem vítimas fatais e com a quantidade total de três fatores contribuintes.

Esses resultados, tanto estatísticos quanto do OPF, são importantes e complementam a Teoria de Reason, pois, considerando a aviação geral, tem-se que além de um acidente acontecer pela ocorrência de mais de um fator contribuinte, quanto maior for a quantidade total de fatores contribuintes, maior a probabilidade de haver vítimas fatais.

Quanto à quantidade de fatores indeterminados em relação à quantidade total de fatores contribuintes, notou-se uma forte relação positiva $(\operatorname{RS}[93]=0,669, \mathrm{p}<0,0005)$, relação que 
já era esperada visto que as variáveis foram calculadas com base em dados semelhantes, pois: fatores "indeterminados" + fatores "contribuiu" = quantidade total de fatores. Nessa análise, com um caminho no OPF, não se encontrou resultado que permitisse análise, com 25 e 50 caminhos, teve-se como padrão a ocorrência de três fatores contribuintes e um fator indeterminado, e aumentando o número de caminhos para 75 e 100, teve-se que o padrão foi de um fator contribuinte e nenhum fator indeterminado.

Isso significa que a quantidade total de fatores aumenta conforme se amplia a quantidade de fatores indeterminados, mas que o padrão que melhor representa essa população foi de acidentes em que o investigador conseguiu afirmar com certeza os fatores contribuintes dos acidentes, o que é um bom indicador de qualidade nas investigações do Cenipa.

\subsection{4 - QUANTIDADE DE MOTORES}

Para analisar a relação entre a quantidade de motores de uma aeronave e a fatalidade dos acidentes, foi utilizado o teste do qui quadrado $\left(\mathrm{X}^{2}\right)$, que mostrou independência entre as duas populações. No entanto, o resultado dessa análise com o OPF se mostrou muito robusto, se mantendo o mesmo quando fornecidos um, 25 e 50 caminhos.

A maior parte dos acidentes da aviação geral acontece com aeronaves monomotoras, no entanto, o resultado encontrado foi que as pessoas tem maior probabilidade de falecer em acidentes com aeronaves bimotoras do que com aeronaves monomotoras, ou seja, acidentes com aeronaves bimotoras tendem a ser mais fatais.

Isso comprova algumas hipóteses levantadas e análises feitas internacionalmente pela Aircraft Owners and Pilots Association ${ }^{11}$ (AOPA, 2015) e o canal de comunicação independente aeronáutica Aviation Publication Group (AVWEB, 2015), ou análises nacionais, como Koch (2013), Rafael (2013), Para Ser Piloto (2013), Canal Piloto (2013), Abag (2013b), entre outros. Esse resultado vai ao encontro dessas análises que explicitam que a segurança de voo não é aumentada, considerando o aspecto material, pelo fato de se ter dois motores em bimotores e apenas um em aeronaves monomotoras.

Enquanto as análises norte-americanas sejam de uma proporção de acidentes muito semelhante para monomotores e bimotores, percebe-se, nas análises brasileiras, a necessidade de atenção para a diferença no treinamento nacional em relação ao norte-americano, em que se ressalta a falta de foco na operação da aeronave bimotora especialmente em situação de pane em um dos motores. Essas análises, apesar de não científicas, são reforçadas pelo resultado encontrado pelo OPF no presente trabalho, pois o resultado comprova que, ao contrário do que muitos pilotos imaginam, aeronaves bimotoras não possuem dois motores por questões de prevenção, mas pela necessidade de dois motores para sua operação em situação normal. Isso significa que em caso de pane em um motor, geralmente se ganha apenas maior tempo e abrangência de área para um pouso de emergência, e não a garantia de

\footnotetext{
${ }^{11}$ Equivalente à Associação de Pilotos e Proprietários de Aeronaves (APPA)
} 
continuar em voo reto (controlado) e nivelado (quanto à altitude) até a pista de destino, por exemplo.

Nesse sentido, ficou evidente a necessidade de aprofundar os estudos nessa área de treinamentos para aeronaves bimotoras "classe", como por exemplo, buscar maneiras de melhorar o treinamento dos pilotos dessas aeronaves, pois a probabilidade de falecimento em caso de acidente, considerando a população analisada (a aviação geral brasileira), foi superior à de uma aeronave monomotora.

Apesar dessas observações, considerando a população analisada, o OPF indica que o padrão mais comum de acidentes, considerando os dois tipos de motorização analisados, foi de acidentes com aeronaves monomotoras e sem fatalidades, muito provavelmente por representarem a maior quantidade de acidentes.

Considerando a quantidade de motores e os fatores indeterminados, observou-se resultado positivo na aplicação do teste $U$ de Mann Whitney, com relação estatisticamente significativa na tabela Rank $(\mathrm{p}=0,034)$. Essa constatação significa que é mais difícil para o investigador afirmar e constatar a presença de fatores contribuintes em aeronaves bimotoras do que em aeronaves monomotoras. Considerando a mesma análise com o OPF, com um caminho não se encontrou resultado que permitisse análise, mas com 25 caminhos, percebe-se um padrão de quatro fatores indeterminados para acidentes com aeronaves bimotoras e de um ou nenhum fator indeterminado para aeronaves monomotoras (o que vai fortalece o que foi encontrado pelo teste $U$ de Mann Whitney), sendo que o padrão sem fatores indeterminados para aeronaves monomotoras foi o mais representativo com 50, 75 e 100 caminhos.

\section{2 - POSSIBILIDADES DE MELHORIA NA APLICAÇÃO DO OPF}

Considerando os trabalhos estudados em que se utilizou o OPF anteriormente, percebeu-se que a maior parte deles se concentrou na parte operacional da ferramenta, por isso buscou-se contribuir de maneira secundária com trabalhos futuros que visem a melhorar a programação o framework, mas, sobretudo com outros pesquisadores que venham a utilizar o mesmo framework, pois durante a utilização do OPF, verificou-se que os resultados obtidos possibilitaram análises consistentes, mas necessitam de cuidado por parte de quem os analisa.

Foi observado, durante as análises dos fatores contribuintes, em que se tinha 57 variáveis possíveis, algo muito importante de ser mais profundamente estudado. Considerando que em cada acidente tem-se em média de quatro a cinco fatores contribuintes - o que equivale a uma média de $8 \%$ dos fatores contribuintes possíveis - esses acidentes necessariamente não possuem 52 dos fatores contribuintes possíveis (o que equivale a 92\% dos outros fatores). Essa observação se faz importante por significar que, na verdade, o fator de mais forte relação entre os acidentes nesses casos foi de negação dos fatores contribuintes e não de sua presença, ou seja, acidentes com a menor quantidade de fatores contribuintes possíveis tenderão a ser escolhidos pelo OPF como mais representativos de um cluster a ser determinado. 
Isso pode ser notada ao analisar a presença constante de acidentes com total de apenas um fator contribuinte. Entende-se que esse resultado foi indicado tantas vezes como padrão não por ser o que oferece a quantidade mais semelhante de fatores em comum, mas pela quantidade de fatores que também não incidem em outros acidentes, o que, matematicamente e computacionalmente, faz sentido.

Outro fator que se considera como limitante à utilização da ferramenta pela comunidade acadêmica de uma maneira geral, é a maneira como é disponibilizada a ferramenta. $\mathrm{O}$ framework, da maneira como é disponibilizado atualmente, acaba por limitá-lo a usuários com conhecimento avançado de computação para programá-la em ambiente Windows, por estar "pronta" para instalação e utilização apenas em sistemas de operação Linux. Acredita-se que sua utilização seria maior se a interface da ferramenta fosse mais "user friendly", considerando a dificuldade por parte de pesquisadores de outras áreas que não sejam a ciência da computação.

Nos subitens seguintes, são realizadas considerações sobre os resultados que não permitiram análises mais profundas, para que se saibam as limitações da ferramenta e do escopo de análises do presente trabalho.

\subsection{1 - EXPERIÊNCIA}

\subsubsection{1 - EXPERIÊNCIA TOTAL}

Considerando experiência total e a quantidade de motores, em que se utilizou o teste $\mathrm{U}$ de Mann Whitney (sem resultado significativo), com 50, 75 e 100 caminhos no OPF, o padrão mais representativo foi de acidentes com aeronaves monomotoras em que o piloto possuía média experiência total, o que não permitiu maiores análises e com um e 25 caminhos não se encontrou resultado que propiciasse a realização de análise consistente.

Utilizando o coeficiente de correlação estatística de Spearman para analisar a quantidade total de fatores indeterminados em relação à experiência total do piloto, não se teve resultados robustos, bem como com um e 25 caminhos do OPF. No entanto, com 50, 75 e 100 caminhos, o padrão demonstrado foi de pilotos de média experiência total e apenas um fator indeterminado, o que também não permitiu maiores análises.

\subsubsection{2 - EXPERIÊNCIA NA AERONAVE DO ACIDENTE}

Com a quantidade de motores e a experiência na aeronave do acidente, utilizando $U$ de Mann Whitney não se encontrou resultado significativo, assim como com um caminho no OPF. Apesar disso, com 25, 50, 75 e 100 caminhos, o padrão encontrado foi de aeronaves monomotoras e com piloto com elevada experiência no equipamento, o que fornece algo semelhante a uma "média", mas não permitiu maiores análises.

\footnotetext{
${ }^{12}$ Expressão da informática para um software de simples ou fácil utilização, amigável para o usuário.
} 
Quanto à quantidade de fatores indeterminados e a experiência na aeronave do acidente, utilizou-se Spearman para testar a correlação estatística, mas não se obteve resultado relevante, assim como com um e 25 caminhos no OPF. Com 50, 75 e 100 caminhos, o padrão mais representativo foi de elevada experiência na aeronave do acidente e um fator contribuinte indeterminado por relatório final de acidente, o que também não permitiu maiores análises.

\subsubsection{3 - EXPERIÊNCIA RECENTE}

Considerando a fatalidade e a experiência recente, não se obteve correlação com o teste $U$ de Mann Whitney e o OPF não permitiu análises profundas, pois com qualquer quantidade de caminhos, os padrões foram sempre de pilotos com experiência média tendo, com 1, 25 e 50 caminhos, um padrão com fatalidades e outro sem, e com 75 e 100 caminhos um padrão sem fatalidades.

Quanto à quantidade de fatores e a experiência recente, não se encontrou relação utilizando Spearman, e com um caminho no OPF, os resultados não permitiram análise. Com 25 e 50 caminhos o OPF indicou como padrão experiência média e três fatores contribuintes, enquanto que para 75 e 100 caminhos, indicou apenas um fator contribuinte como sendo o padrão.

Em relação à quantidade de motores e a experiência recente do piloto utilizando o teste $U$ de Mann Whitney, não se encontrou correlação e com o OPF, nota-se apenas que o padrão mais representativo foi de acidentes com aeronaves monomotoras em que o piloto possuía média experiência recente.

Para se analisar a correlação estatística da quantidade de fatores indeterminados e a experiência recente, utilizou-se Spearman, que não mostrou correlação nas análises, bem como um e 25 caminhos no OPF. Já com 50, 75 e 100 caminhos, o OPF indica como padrão, média experiência recente e a presença de apenas um fator contribuinte indeterminado em cada relatório final, o que também não permite análises profundas.

De maneira geral, com os resultados da pesquisa sobre experiência recente, não se encontrou nada que possibilite maior análise que contribua para a prevenção de acidentes, a não ser que a maior parte dos pilotos envolvidos nos acidentes possuía experiência média.

\subsubsection{4 - EXPERIÊNCIAS COMBINADAS}

Para iniciar o estudo dos padrões relacionados à experiência, buscou-se analisar a existência de um padrão de experiência ou de qualquer relação entre os níveis dos três tipos de experiência de maneira combinada. Nessa análise, teve-se resultado positivo na estatística ao se utilizar o coeficiente de Spearman, em que se encontrou uma relação (RS [71] = 0,370, p = 0,002) existente entre o número de horas de experiência na aeronave acidentada e o número 
total de horas de experiência, isto é, quanto maior o número de horas do piloto na aeronave do acidente, maior o número total de horas de experiência.

Isso permitiu deduzir que na maioria dos casos, quanto mais experiente o piloto, menor a chance do mesmo voar uma mesma aeronave por pouco tempo, como acontece em empregos freelance ou de ocasião, ou seja, significa que pilotos mais experientes costumam voar aeronaves que já conhecem quando se acidentam, e não aeronaves estranhas/desconhecidas para o profissional.

Considerando a análise do OPF dos níveis das três variáveis de experiência combinadas dos pilotos mais relevantes na população estuda, com 25 caminhos, verificou-se o padrão demonstrado no Quadro 4.13.

Quadro 4.13 - Padrões de experiência dos pilotos com 25 caminhos (elaborado pelo autor).

\begin{tabular}{|c|c|c|c|}
\hline & Experiência total & Experiência recente & $\begin{array}{c}\text { Experiência na aeronave do } \\
\text { acidente }\end{array}$ \\
\hline Padrão 1 & Baixa & Média & Baixa \\
\hline Padrão 2 & Alta & Alta & Alta \\
\hline Padrão 3 & Média & Baixa & Alta \\
\hline
\end{tabular}

Considerando o exposto no Quadro 4.13, o Padrão 2 confirma o que foi encontrado pelo coeficiente de Spearman. No entanto, ao se aumentar a quantidade de caminhos (para 50, 75 e 100), verifica-se que o padrão mais representativo da população foi o Padrão 3. Isso significa que o padrão de experiência combinada que se encontrou, foi de pilotos com média experiência total, média experiência recente, e com elevada experiência na aeronave do acidente, o que permite complementar a análise estatística da seguinte forma: pilotos com média e elevada experiência total tendem a voar as mesmas aeronaves com maior frequência, enquanto que pilotos com baixa experiência total acabam por voar as mesmas aeronaves com menor frequência. Apesar dessa análise, optou-se por ressaltar que não seria possível chegar a essa conclusão apenas com o OPF, por isso categorizou-se essa análise como uma possibilidade de melhoria na ferramenta.

Comparando os níveis das três variáveis de experiência combinadas e sua relação com a fatalidade, não se utilizou a estatística. Com o OPF e um caminho os resultados não permitiram análise e com 25, 50, 75 e 100 caminho teve-se como padrão a não ocorrência de fatalidades, mas sem relação com a experiência de uma maneira geral - ou seja, sem possibilidade de análises relevantes no ponto de vista da prevenção.

Ao se analisar os níveis das três variáveis de experiência combinadas com a quantidade total de fatores contribuintes, em que também não se utilizou estatística, com um caminho os resultados também não permitiram análise. Com 25 e 50 caminhos, teve-se como padrão a 
quantidade três fatores contribuintes e com 75 e 100 caminhos apenas um fator contribuinte, mas nenhuma relação desses padrões com as experiências combinadas, o que limitou as análises.

Quanto à análise dos tipos de fatores e os níveis das três variáveis de experiência combinadas, também não se utilizou estatística. No OPF, com um, 25 e 50 caminhos, os resultados não permitiram análise e com 75 e 100 caminhos, teve-se como padrão, pilotos com média experiência total, média experiência recente e elevada experiência na aeronave do acidente tendo apenas um fator contribuinte, sendo esse fator o "esquecimento".

A conclusão a que se chegou é que considerando os níveis das três variáveis de experiência combinadas com a quantidade total de fatores contribuintes, com os tipos de fatores contribuintes e com a fatalidade, verificou-se que os resultados não proporcionam maiores análises, tendo-se como resultado apenas que, considerando essas variáveis nessa população definida, o padrão mostra acidentes pouco fatais como sendo os que melhor representam, e o padrão tendendo à ocorrência de apenas um fator contribuinte, sendo esse fator $\mathrm{o}$ esquecimento.

\subsection{2 - FATORES INDETERMINADOS}

A fim de analisar a relação entre fatalidade e a dificuldade do investigador em estabelecer os fatores contribuintes para verificar se o investigador possui mais dificuldade em afirmar a contribuição do fator nos casos em que pessoas faleceram no acidente, colocando os fatores contribuintes como indeterminados, utilizou-se o teste $U$ de Mann Whitney. No entanto, tanto nessa análise estatística quanto nos resultados obtidos do OPF com qualquer número de caminhos, o método mostrou que não existe relação.

Para analisar a relação entre a qualificação dos pilotos e a quantidade de fatores indeterminados, utilizou-se o coeficiente de Spearman, sem resultados estatisticamente significativos. No OPF, com um caminho não se encontrou resultado que permitisse análise, com 25 caminhos, teve-se como padrão a quantidade de dois fatores indeterminados para pilotos comerciais (PC), cinco fatores indeterminados para pilotos comerciais IFR (PC IFR) e um fator para pilotos com curso da aeronave (Tipo). Esse último padrão de um fator para pilotos com curso da aeronave se repetiu com 50, 75 e 100 caminhos e em nenhuma quantidade de caminhos houve padrão na ocorrência de fatores indeterminados para pilotos privados.

\subsection{3 - MOTORIZAÇÃO}

Quanto à quantidade de motores e a qualificação dos pilotos, encontrou-se relação estatisticamente significativa $(\mathrm{p}=0,001)$ na tabela Rank utilizando U de Mann Whitney. Essa constatação é relevante, pois significa que, na população considerada, os pilotos de aeronaves bimotoras costumam ser mais qualificados do que os de monomotoras, ou seja, a tripulação de 
uma aeronave bimotora costuma ser mais bem selecionada considerando o nível de qualificação. No entanto, chama a atenção o fato do OPF não ter encontrado nenhum resultado possível de ser analisado.

Em relação à quantidade total de fatores e a quantidade de motores, verificou-se que os resultados tendem a ser de três fatores para aeronaves bimotoras e de quatro fatores para monomotoras, o que não permite maiores análises desses resultados. Portanto, mesmo com um resultado robusto, não se verificou particularidades específicas à motorização da aeronave. Esse resultado surpreendeu, pois se esperava alguma relação como, por exemplo, aeronaves bimotoras possuírem maior número de fatores contribuintes, ou seja, mais falhas seriam necessárias para que um acidente viesse a ocorrer com estas aeronaves, o que não foi demonstrado nos resultados.

\subsection{4 - COPILOTO}

Para as análises de correlação entre a presença de copiloto e a experiência da tripulação experiência total do piloto, experiência recente do piloto e experiência do piloto na aeronave do acidente - foram conduzidos os testes $U$ de Mann Whitney em que não se encontrou resultado que indicasse correlação. $\mathrm{O}$ mesmo teste foi conduzido para analisar a presença de copiloto e a quantidade total de fatores contribuintes, e a presença de copiloto e a quantidade de fatores indeterminados, igualmente sem resultado analisável. Para todas essas análises, não se obteve resultados robustos com o OPF independente da quantidade de caminhos (um, 25, 50, 75 e 100). A única observação a ser feita se refere à quantidade total de fatores contribuintes e a presença de copiloto, em que ao se fornecer apenas um caminho na análise, verifica-se que acidentes com copiloto tendem a possuir seis fatores contribuintes.

Em relação à quantidade de motores e a presença de copiloto, bem como à fatalidade e a presença de copiloto, optou-se por utilizar o teste de qui quadrado $\left(\mathrm{X}^{2}\right)$, em que não se encontrou correlação, assim como não se encontrou resultado robusto com qualquer quantidade de caminhos (um, 25, 50, 75 e 100) do OPF.

Independente do número de caminhos estabelecidos, também não se encontrou resultado robusto no OPF para a presença de copiloto e a análise dos tipos de fatores, em que não foi utilizada a estatística.

Acredita-se que a baixa quantidade de relatórios de acidentes em que existia copiloto (apenas cinco) pode ter influenciado no resultado não robusto dessas análises, o que pode ser levado em conta em estudos futuros de aplicação do OPF em amostras relativamente pequenas como a desse trabalho. 


\section{3 - ANÁLISES COMPLEMENTARES}

Durante a extração dos dados foi realizado estudo e análise de alguns relatórios finais, em que foram notadas algumas características que são consideradas importantes de serem observadas com maior atenção, podendo ser, inclusive, tema de estudos futuros.

Considerando os relatórios levantados, nos dois casos em que se tratava de acidentes com aeronaves de lançamento de paraquedistas houve divergência na categorização dos paraquedistas. No acidente da aeronave PT-OQR os paraquedistas foram categorizados como "terceiros", enquanto no acidente da aeronave PT-BXQ, os paraquedistas foram classificados como "passageiros". Acredita-se que seja necessário explicitar o critério para se categorizar os paraquedistas como terceiros ou passageiros, sendo que, na opinião do autor do presente trabalho, a princípio, pareceu mais adequado categorizá-los como passageiros, visto que foram passageiros durante um determinado período da operação.

Uma observação também pode ser feita quanto às informações do relatório final do acidente PT-VMG, de uma aeronave modelo EMB-720 D que teve falha de motor em voo após a decolagem, em que se verificou discrepância com relação ao número de passageiros e tripulantes. No texto do histórico, foi mencionada a presença de um piloto e quatro passageiros, totalizando cinco pessoas, enquanto que no quadro de danos pessoais, foi apresentado o número de dois tripulantes e um passageiro. Esse tipo de discrepância, apesar de raro, cria desconfiança nos dados apresentados pelos relatórios, o que pode diminuir a sua credibilidade e assim, prejudicar a sua utilização para fins de prevenção.

Outro aspecto observado diz respeito ao relatório final do acidente da aeronave PT-KYD, que tratava de uma colisão de duas aeronaves em rota. No caso desse acidente, no presente trabalho, foram consideradas apenas as informações referentes à aeronave PT-KYD, modelo U206G, desprezando os fatores do PP-XIG, modelo Regente, pelo fato desta segunda ser uma aeronave de categoria experimental e, portanto, não investigada pelo Cenipa. Levanta-se a relevância de discussões sobre a maneira como são conduzidas investigações de acidentes entre aeronaves da categoria "avião" e aeronaves da categoria "experimental", ou até mesmo como serão tratados acidentes envolvendo os VANTs ${ }^{13}$, cada vez mais comuns no espaço aéreo mundial e ainda com grande expectativa de aumento em sua frota.

Notou-se também que, dos 146 acidentes levantados inicialmente como sendo da aviação geral, apenas três aconteceram com aeronaves turboélices, sendo elas dos modelos C208 (dois acidentes) e TBM700B (um acidente). Como não se conseguiu dados sobre a quantidade de aeronaves dividida por tipo de motor no Brasil nos anos estudados, não foi possível analisar se esse número pequeno se explica por serem mais seguras do que aeronaves à pistão ou por sua quantidade ser inferior à de aeronaves à pistão. No entanto, consideram-se relevantes estudos futuros que abordem a diferença de segurança oferecida pelo tipo de motorização, bem como relacionados à quantidade de motores das aeronaves.

\footnotetext{
${ }^{13}$ Veículos Aéreos Não Tripulados
} 
Nos relatórios finais, uma boa prática foi encontrada no relatório do acidente do PR-IAO, aeronave modelo SR22 que perdeu potência e colidiu contra o solo após ser abastecida com o combustível errado. Nesse relatório, foi realizada uma descrição completa de cada um dos envolvidos no acidente, algo não notado em muitos dos outros relatórios analisados nesse trabalho. No item "1.13.3 Aspectos Psicológicos" (Brasil, 2015g), por exemplo, foi feita a explicação do procedimento adotado nessa análise específica do relatório, que pode ser considerada como uma prática a ser repetida em futuras investigações de acidentes: "Visando melhor abrangência e descrição dos dados da investigação, por meio de entrevistas, foram obtidas informações acerca do proprietário da aeronave, do piloto da aeronave e do operador de abastecimento" (Brasil, 2015g, p. 14).

Se o próprio investigador considerou que essa prática possibilitaria melhor abrangência e descrição, ela deve ser recomendada a todos os relatórios - e não apenas a esse específico para que se tenha a maior quantidade de informações e dados possível sobre os acidentes a fim de evitar novas ocorrências.

Ainda quanto ao trabalho do investigador na elaboração dos relatórios finais, algumas observações realizadas pelo Cenipa nesses relatórios parecem confusas quando se considera a legislação aeronáutica vigente. Esse foi o caso do relatório final do acidente da aeronave PTJKU, de uma aeronave modelo V-35B que colidiu com o solo, em que o investigador afirma que o piloto, possuidor de licença de Piloto Comercial, possuía experiência suficiente apenas para voar no Estado de Minas Gerais, o que não faz sentido. Licenças de Piloto Comercial abrangem todo o território nacional, e não apenas um Estado da Federação ou região específica. Além disso, nesse relatório, o Cenipa indica a falta de copiloto como um possível fator, mesmo não sendo obrigatório para esse modelo de aeronave, bem como essa característica não ser destacada em outros relatórios similares.

Outro aspecto observado ocorreu no acidente da aeronave PT-DON, uma aeronave modelo PA-24-260 que arremeteu na reta final e realizou curva à esquerda, perdendo altura até colidir com o solo, em que se questionou a imparcialidade ou subjetividade na avaliação dos fatores. O que motivou esse questionamento foi a afirmação "o piloto estava qualificado para realizar o tipo de voo" (Brasil, 2015e, p. 7), justificada no relatório pela afirmação "o fato de o piloto ser oficial aviador da reserva da Força Aérea Brasileira (FAB) sugere uma experiência suficientemente adequada na atividade aérea" (Brasil, 2015e, p. 7), pois apenas o fato de ser oficial aviador da reserva da Força Aérea Brasileira não poderia ser considerado suficiente, visto que nesse relatório não são divulgados dados sobre a quantidade de horas totais, experiência recente ou quantidade de horas no mesmo modelo de aeronave do acidente. Ainda em se tratando desse relatório e considerando que houve uma sobrevivente nesse acidente, fica difícil compreender porque todos os fatores contribuintes apontados foram considerados como "indeterminados", sem ser indicado um único fator "contribuiu".

Questionamentos sobre a imparcialidade também surgiram ao analisar o relatório final do acidente da aeronave PT-JAY, de uma aeronave Cessna modelo $337 \mathrm{G}$ que realizou pouso forçado após corte involuntário dos motores por outro piloto formado pela Aeronáutica. O que 
motivou a dúvida foi o piloto possuir 2.612 horas de voo no tipo de aeronave sem possuir habilitação para tal. Seguindo o padrão dos outros relatórios, isso poderia ser considerado, por exemplo, ao menos como fator "indeterminado", encaixando-se como fator "Humano Operacional - Supervisão Gerencial" por parte do órgão que recebeu o plano de voo, bem como o fator "Humano - Hábito adquirido" pelo fato do número de horas na aeronave que o piloto possuía voando sem ter a licença adequada. Acredita-se também que o fator "Humano Operacional - Instrução" não deveria ser apenas "indeterminado", mas um fator constatado como "contribuiu", visto que o piloto não a realizou formalmente.

\section{5 - CONCLUSÕES E RECOMENDAÇÕES}

Foi possível identificar e também analisar os padrões de ocorrência dos fatores contribuintes e de diversas outras características ligadas aos acidentes, sendo possível, portanto, se basear nos resultados expostos no presente trabalho para alterar e adicionar exigências ligadas tanto ao treinamento e certificação dos pilotos, quanto de sua experiência. A consideração e utilização desses resultados por órgãos como o Cenipa e a Anac revelariam empenho e dedicação quanto à melhoria na capacitação dos recursos humanos, em especial dos pilotos, uma medida simples, se comparada a outras, e essencial para aumentar consideravelmente a segurança da operação na aviação geral.

Nesse trabalho, descobriu-se que tanto a experiência total do piloto quanto a qualificação influenciam na fatalidade dos acidentes da aviação geral, ou seja, pilotos menos experientes (com menos horas de voo na carreira) ou com menor qualificação (apenas Piloto Privado, por exemplo), quando se envolvem em acidentes, acabam por ter uma incidência maior de vítimas fatais do que pilotos mais experientes ou mais bem qualificados (com curso específico da aeronave, por exemplo). Ainda sobre as fatalidades, notou-se que pilotos com maior experiência na aeronave do acidente também diminuem a probabilidade do acidente ter vítimas fatais. A experiência recente (dos últimos 30 dias) mostrou não ter influenciado em nenhuma característica dos acidentes analisados, podendo ser menos considerada nas análises pelos investigadores. A quantidade de motores da aeronave também mostrou ter relação com as fatalidades, visto que os acidentes com aeronaves bimotoras tendem a ser mais bem representados por aqueles com vítimas fatais. A estatística mostrou ainda, que é mais difícil determinar fatores contribuintes em aeronaves bimotoras, o que dificulta um pouco mais descobrir elementos que poderiam ser motivo de foco para futuros treinamentos de prevenção de acidentes em bimotores.

Quanto à Teoria de Reason, percebeu-se que se podem adicionar alguns elementos à mesma, em se tratando da aviação geral brasileira. Primeiro, quanto maior a experiência total do piloto, maior a quantidade total de fatores para a ocorrência de um acidente. No entanto, quanto maior a sua experiência na aeronave do acidente e a sua qualificação, menos fatores contribuintes são necessários para que aconteça um acidente, ou seja, menos falhas latentes são necessárias para que ocorra um acidente com um piloto altamente qualificado ou com grande experiência, sendo a falha ativa de extrema importância nesses casos. Ainda em se 
tratando da Teoria de Reason, percebeu-se que quanto mais fatores contribuintes, maior a probabilidade do acidente ter vítimas fatais.

Quanto à presença de copiloto, a única relação encontrada foi com o nível de qualificação por meio da estatística. Considerando que a presença de copiloto em aeronaves da aviação geral não é obrigatória, pode-se concluir que existe um perfil de proprietários de aeronaves mais preocupados quanto à tripulação, preferindo pilotos com maior nível de qualificação e com a presença de um copiloto.

O fator contribuinte "esquecimento" apareceu como sendo o que melhor representa os fatores contribuintes, no entanto, cogita-se que esse resultado seja enviesado devido à quantidade de negações (56) de outros fatores serem a principal característica, e não pela semelhança com fatores contribuintes de outros acidentes.

Percebeu-se, nas análises complementares, que é necessário que o órgão investigador esclareça os critérios utilizados pelos investigadores quanto à contabilização das pessoas envolvidas em acidentes, especialmente nos casos de voos que transportam paraquedistas. Também se consideram importantes, discussões sobre como serão conduzidas e analisadas as investigações envolvendo mais de uma aeronave, especialmente acidentes envolvendo aeronaves da categoria "avião" com aeronaves da categoria "experimental" ou com VANTs.

Sugere-se também ao órgão investigador que procure utilizar-se da boa prática adotada no acidente PR-IAO quanto à riqueza de informações e análises realizada, bem como melhores explicações sobre o que é abordado sem profundidade quanto à legislação vigente nos relatórios para evitar questionamentos como os existentes no acidente do PT-JKU em que não ficam claros os limites da aplicação da lei. Além disso, considera-se necessária a participação de membros do Sipaer que não sejam da Força Aérea Brasileira como responsável por relatórios envolvendo pilotos que já tenham sido da FAB para que se evitem casos de aparente imparcialidade como dos acidentes das aeronaves PT-DON e PT-JAY, em que sentiu-se falta de melhores explicações quanto ao infringir de leis e regulamentos dos pilotos em questão. Esse é um indício de que seria de grande valia que o Cenipa buscasse uma característica cada vez mais distante do órgão militar ao qual está vinculado, para que possa ser mais conhecido como um órgão de investigação ligada à prevenção do que um órgão militar de investigação, o que pode inibir resultados que seriam proveitosos à prevenção de novos acidentes aeronáuticos.

\section{1 - LIMITAÇÕES E RECOMENDAÇÕES}

Perceberam-se algumas limitações na utilização do OPF para algumas análises, as quais devem ser levadas em conta em estudos futuros utilizando o método em pequenas amostras:

- Considerando experiência total, não foi possível relacioná-la com a quantidade de motores e com a quantidade total de fatores indeterminados. Quanto à experiência na aeronave do acidente, não se encontrou resultados analisáveis relacionando-a tanto 
- com a quantidade de fatores indeterminados como com quantidade de motores. As informações sobre a experiência recente não demonstraram resultados quando analisadas em relação à fatalidade, e às quantidades de fatores, motores e fatores indeterminados. Ao se conduzir a análise dos fatores contribuintes indeterminados, não se encontrou relação com a qualificação dos pilotos nem com as fatalidades. Também ao se considerar a quantidade de motores, não foi encontrada relação com a qualificação dos pilotos, a quantidade total de fatores.

- A existência de um padrão de experiência ou de qualquer relação entre os níveis dos três tipos de experiência de maneira combinada não permitiria maiores análises caso tivesse sido utilizado apenas o OPF sem a complementação estatística, motivo pelo qual se ressalta essa análise como uma possibilidade de melhoria na utilização do método. Essa sugestão se dá também por não terem sido possíveis análises sobre a relação dessas três variáveis de experiência combinadas com outras características (fatalidade, quantidade total de fatores contribuintes, e tipos de fatores).

- Quanto à presença de copiloto, não se pôde analisá-la com a experiência da tripulação, a quantidade total de fatores contribuintes, quantidade de fatores indeterminados, a quantidade de motores, a fatalidade, e os tipos de fatores. Acredita-se que a baixa quantidade de relatórios de acidentes em que existia copiloto (cinco) influenciou nessa limitação.

Outra limitação do presente estudo se deu devido à dificuldade em se encontrar dados tabelados com a quantidade de aeronaves dividida por modelo de aeronave ou tipo de motor. Considera-se que essas informações seriam importantes para uma análise conjunta com as características dos acidentes, para se refletir sobre as medidas de prevenção específicas às aeronaves à pistão ou turboélices, monomotoras ou bimotoras.

\section{REFERÊNCIAS BIBLIOGRÁFICAS}

AFONSO, L. C. S. (2013) Composição de dicionários visuais utilizando agrupamento de dados por flores de caminhos ótimos / Luis Claudio Sugi Afonso. - São José do Rio Preto: [s.n.], 2013

AIR TRACTOR (2015) Modelo AT-802A. Disponível em: <http://www.airtractor.com> Acesso em 08 jul. 2015.

AMALBERTI, R. (1996) La conduite de systemes à risques. Paris. Press Universitaires de France.

ANAC (2003) Registro Brasileiro de Homologação Aeronáutica - RBHA 47 Funcionamento e atividades do sistema de registro aeronáutico brasileiro. Disponível em: <http://www2.anac.gov.br/biblioteca/rbha/rbha047.pdf> Acesso em 30 Abr. 2015. 
ANAC (2013) Resolução No 293, de 19 de novembro de 2013. Dispõe sobre o Registro Aeronáutico Brasileiro $e$ dá outras providências. Disponível em: http://www2.anac.gov.br/biblioteca/resolucao/2013/RA2013-0293.pdf Acesso em 08 dez. 2015.

AIRCRAFT OWNERS AND PILOTS ASSOCIATION. AOPA. (2015) Single vs Twin: Which is Safer? Disponível em: <http://www.aopa.org/Pilot-Resources/PIC-archive/FlightTraining-Ratings-and-Proficiency/Single-vs-Twin.aspx> Acesso em 16 dez. 2015

ARAUJO, M. A. A. BEZERRA, R. S. M. (2007) Redução dos Acidentes no Brasil Ocasionados por Fenômenos Meteorológicos. Monografia de Especialização em Aviação Civil. Centro de Formação de Recursos Humanos em Transportes. Universidade de Brasília. Brasília, DF.

ASSOCIAÇÃO BRASILEIRA DE AVIAÇÃO GERAL (ABAG). (2013a) Anuário Brasileiro de Aviação Geral - 2013. Disponível em: 〈http://www.abag.org.br> Acesso em 11 jul. 2014.

ASSOCIAÇÃO BRASILEIRA DE AVIAÇÃO GERAL (ABAG) (2013b) Disponível em: $<$ http://www.abag.org.br/assets/seg_voo-falha_de_motor_em_bimotor_leve.pdf> Acesso em 14 dez. 2015.

ASSOCIAÇÃO BRASILEIRA DE AVIAÇÃO GERAL (ABAG). (2015) Anuário Brasileiro de Aviação Geral - 2015. Disponível em: <http://www.abag.org.br> Acesso em 11 jan. 2016.

AVIATION PUBLICATION GROUP. AVWEB (2015). Do You Really Want a Twin? Disponível em <http://www.avweb.com/news/usedacft/182809-1.html> Acesso em 14 dez. 2015.

AXELROD, R; COHEN, M. (2001) Harnessing Complexity. Prentes Hall.

BARRETO, M. R. M. (2008) A contribuição da psicologia para a segurança da atividade aeronáutica. XXVIII Encontro Nacional de Engenharia de Produção (ENEGEP).

BENSON, A. J. (1998) Spatial Disorientation - common ilusions. Aviation Medicine.

BEECHCRAFT (2015) Beechcraft Corporation. Textron Aviation. Disponível em: $<$ http://beechcraft.txtav.com/> Acesso em 04 mai. 2015

BRASIL. (1946) Decreto 21.713, de 27 de agosto de 1946. Promulga a Convenção sobre Aviação Civil Internacional, concluída em Chicago a 7 de dezembro de 1944 e firmado pelo Brasil, em Washington, a 29 de maio de 1945. Disponível em: <http://www.planalto.gov.br/ccivil_03/decreto/1930-1949/D21713.htm> Acesso em: 22 jun. 2014.

BRASIL. (1971) Decreto $\mathrm{n}^{\circ}$ 69.565, de 19 de Novembro de 1971. Institui o Sistema de Investigação e Prevenção de Acidentes Aeronáutica, e dá outras providências. Coleção de Leis do Brasil - 1971. p. 221. Vol. 8. 
BRASIL. (1982) Decreto $\mathrm{n}^{\circ}$ 87.249, de 7 de Junho de 1982. Dispõe sobre o Sistema de Investigação e Prevenção de Acidentes Aeronáuticos e dá outras providências. Coleção de Leis do Brasil - 1982. p. 189. Vol. 4.

BRASIL. (1986) Lei no 7.565, de 19 de dezembro de 1986. Código Brasileiro de Aeronáutica $-C B A$. Brasília, DF.

BRASIL. (2005) Lei $\mathrm{n}^{\circ}$ 11.182, de 27 de setembro de 2005. Cria a Agência Nacional de Aviação Civil - ANAC, e dá outras providências. Diário Oficial [da] República Federativa do Brasil, Brasília, DF. N 187, S/1, p.1-8.

BRASIL. (2011) Manual de Investigação do Sipaer (MCA) 3-6. Comando da Aeronáutica. Centro de Investigação e Prevenção de Acidentes Aeronáuticos. <http://www.cenipa.aer.mil.br/cenipa/index.php/legislacao/category/7-mca-manual-docomando-da-aeronautica> Acesso em 31. jul. 2014.

BRASIL. (2012a) Anuário do Transporte Aéreo 2012. Disponível em: <http://www2.anac.gov.br/estatistica/anuarios.asp> Acesso em: 07 jun. 2014.

BRASIL. (2012b) Regulamento Brasileiro da Aviação Civil (RBAC) $n^{o}$ 61: Licenças, habilitações e certificados. Disponível em: <http://www2.anac.gov.br/biblioteca/rbac/> Acesso em: 31 jul. 2014.

BRASIL. (2013) Folheto do Comando da Aeronáutica (FCA) 58-1. Panorama Estatístico da Aviação Civil Brasileira em 2012. Disponível em http://www.cenipa.aer.mil.br/ Acesso em 31 jul. 2014.

BRASIL. (2014a) Demanda e Oferta do Transporte Aéreo - Empresas Brasileiras. Abril de $2014 . \quad$ Disponível em: <http://www2.anac.gov.br/estatistica/demandaeoferta/DemandaeOferta.asp> Acesso em: 21 jun. 2014.

BRASIL. (2014b) Comando da Aeronáutica. Centro de Investigação e Prevenção de Acidentes Aeronáuticos. Histórico. Disponível em: <http://www.cenipa.aer.mil.br/cenipa/index.php/o-cenipa/historico> Acesso em 16. abr. 2014.

BRASIL. (2014c) Folheto do Comando da Aeronáutica (FCA) 58-1. Panorama Estatístico da Aviação Civil Brasileira em 2013. Disponível em http://www.cenipa.aer.mil.br/ Acesso em 11 jan. 2016.

BRASIL. (2015a) Centro de Investigação e Prevenção de Acidentes Aeronáuticos - Comissão de Investigação de Acidente Aeronáutico. Disponível em: <http://www.cenipa.aer.mil.br/cenipa/index.php/component/content/article/artigoscenipa/113-comissao-de-investigacao-de-acidente-aeronautico> Acesso em 01. mai. 2015.

BRASIL. (2015b) Comando da Aeronáutica. Centro de Investigação e Prevenção de Acidentes Aeronáuticos. Disponível em: <http://www.cenipa.aer.mil.br> Acesso em 01. mai. 2015. 
BRASIL. (2015c) Comando da Aeronáutica. Centro de Investigação e Prevenção de Acidentes Aeronáuticos - Relatórios Finais. Disponível em: <http://www.cenipa.aer.mil.br/cenipa/paginas/relatorios/relatorios-finais> Acesso em 13. dez. 2015.

BRASIL (2015d) Relatório do acidente PT-LKH. Disponível em: <http://www.cenipa.aer.mil.br/cenipa/paginas/relatorios/relatorios-finais> Acesso em 13. dez. 2015.

BRASIL (2015e) Relatório do acidente PT-DON. Disponível em: <http://www.cenipa.aer.mil.br/cenipa/paginas/relatorios/relatorios-finais> Acesso em 13. dez. 2015.

BRASIL (2015f) Relatório do acidente PT-RYC. Disponível em: <http://www.cenipa.aer.mil.br/cenipa/paginas/relatorios/relatorios-finais> Acesso em 13. dez. 2015.

BRASIL (2015g) Relatório do acidente PR-IAO. Disponível em: <http://www.cenipa.aer.mil.br/cenipa/paginas/relatorios/relatorios-finais> Acesso em 13. dez. 2015.

CANAL PILOTO (2013) Bimotores leves: ilusão fatal. Disponível em: <http://canalpiloto.com.br/bimotores-leves-ilusao-fatal/> Acesso em: 14 dez. 2015

CARDELLA, B. (1999) Segurança no Trabalho e Prevenção de Acidentes: Uma Abordagem Holística. São Paulo: Editora Atlas.

CASTLES, S. (2002) Migration und Community Formation under Conditions of Globalization. International Migration Review. v. 36. $\mathrm{n}^{\circ}$ 4. Center for Migration Studies of New York.

CESSNA (2015) Cessna Aircraft Company. Textron Aviation. Disponível em: $<$ http://cessna.txtav.com/> Acesso em 04 mai. 2015

CUNHA, A. G. (1997) Dicionário etimológico nova fronteira da Língua Portuguesa. $2^{\mathrm{a}}$

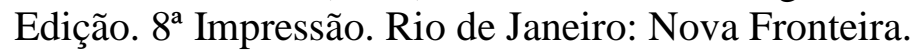

DA SILVA, T. H. C. (2008) Re-regulação no mercado de aviação civil: necessária ou não? Monografia da Secretaria de Acompanhamento Econômico. III Prêmio SEAE, Monografias em defesa da concorrência e regulação econômica. Distrito Federal. Disponível em: <http://www.seae.fazenda.gov.br/conheca_seae/premio-seae/iiipremioseae/estudantes/monografia22.pdf/view>. Acesso em: 20 mar. 2015.

DEKKER, S. W. A. (2002) The field guide to understanding human error. Aldershot, UK. Ashgate Publishing.

DOD HFACS. (2005) A mishap investigation and data analysis tool. Department of Defense Human Factors Analysis and Classification System. Disponível em: <http://www.uscg.mil/safety/docs/ergo_hfacs/hfacs.pdf> Acesso em: 31 jul. 2014. 
FALCÃO, A. X., STOLFI, J., LOTUFO R. A. (2004) The image foresting transform: Theory, algorithms, and applications. IEEE Transactions on Pattern Analysis and Machine Intelligence, 26.19-29, Jan 2004.

FANGUEIRO, A. F. A. (2008) Avaliação do contributo da evolução tecnológica para a segurança no transporte aéreo. Dissertação de Mestrado. Universidade da Beira Interior. Covilhã, Portugal.

FEOFILOFF, P. KOHAYAKAWA, Y. WAKABAYASHI, Y. (2011) Uma introdução sucinta à Teoria dos Grafos. Disponível em http://www.ime.usp.br/ pf/teoriadosgrafos/texto/TeoriaDosGrafos.pdf> Acesso em 03 abr. 2015

FLICKR (2015) Usuário brucek68. Disponível em: <https://www.flickr.com/photos/brucek68> Acesso em 09 jul. 2015

GILlingHAM, K. K. PREVIC, F. H. (1996) Spatial orientation in flight. In RL DeHart (Ed.), Fundamentals of aerospace medicine. Philadelphia: Lea \& Febiger.

GRABOWSKI, F. STRZALKA, D. (2008) Simple, complicated and complex systems - the brief introduction. Rzeszow University of Technology, Department of Distributed Systems, Rzeszow, Poland. IEEE.

HAWKINS, F. H. (1984) Human factors education in european air transport operations. In: Breakdown in human adaptation to stress. v.1. Netherlands: Martinus Nijhoff.

HAWKINS, F. H. (1993) Human factors in flight. Aldershot: Ashgate.

HELIBRAS (2015) Helibras: Airbus Helicopters. Modelo Dauphin AS365. Disponível em: <http://www.helibras.com.br> Acesso em 07 jul. 2015

HELMREICH, R. L. (1998) Error management as organizational strategy. In: Proceedings of the IATA. Human Factors Seminar. Bangkok, Thailandia.

HESPANHOL, R. M. PEREIRA, D. R. FORTES, J. A. A. S. (2015) Padrões nos Acidentes na Aviação Geral Brasileira utilizando Floresta de Caminhos Ótimos. Air Transportation Symposium. Sitraer 2015. São José dos Campos, SP.

ILIEV, A. I. SCORDILIS, M. S. PAPA, J. P. FALCÃO, A. X. (2010) Spoken emotion recognition through optimum-path forest classification using glottal features, Computer Speech \& Language, Volume 24, Issue 3, July 2010, Pages 445-460, ISSN 0885-2308.

KOCH, S. (2013) Asas do Conhecimento (Blog). Monomotor em bimotor leve. Disponível em: <https://sites.google.com/site/invacivil/temas-ja-discutidos/monomotor-em-bimotorleve> Acesso em 14 dez. 2015.

LET MODEL (2015) Modelo ASH 26. Disponível em: 〈http://www.letmodel.cz> Acesso em 07 jul. 2015 
LEVESON, N. G. (2002) A new approach to system safety engineering. Massachussets: Institute of Technology.

MADEIRA, V. C. (2008) O que o Sipaer tem feito para diminuir os riscos de acidentes aeronáuticos do país. $7^{\circ}$ Simpósio de Transporte Aéreo. Rio de Janeiro.

MARQUES, C., GUILHERME, I., NAKAMURA, R., PAPA, J. (2011). New Trends in Musical Genre Classification Using Optimum-Path Forest. In Proceedings of the 12th International Society for Music Information Retrieval Conference. Miami (Florida), USA. October 24-28. pp. 699-704.

MARQUES, E. (2004) Fator humano. In: Instituto de fomento e coordenação industrial (IFI). Seminário Internacional de Fator Humano, São José dos Campos, Anais. São José dos Campos, SP. CTA, 6/7 out. 2004.

MARTINS, D. A., GUIMARÃES, L. A. M., LANGE FILHO, R., SIQUEIRA, L. da V. R. O (2006) Conceito de Fatores Humanos na Aviação. Qualidade de Vida e Fadiga Institucional, Campinas, p.203-218. Disponível em:

www.bibliotecadigital.unicamp.br/document/?down=000360590 >. Acesso em: 08 dez. 2015.

MCKINSEY \& COMPANY DO BRASIL (2010) Estudo do setor de transporte aéreo do Brasil: relatório consolidado. Rio de Janeiro, Disponível em: <http://www.bndes.gov.br/SiteBNDES/export/sites/default/bndes_pt/> Acesso em: 02 jun. 2014.

ORGANIZAÇÃO DA AVIAÇÃO CIVIL INTERNACIONAL (OACI). (2003) Human Factors Guidelines for Aircraft Maintenance Manual. Doc. 9824. Montreal, Canada. OACI. Disponível em: <http://www.icao.int/ANB/humanfactors/Documents.html> Acesso em jun. 2014.

ORGANIZAÇÃO DA AVIAÇÃO CIVIL INTERNACIONAL (OACI). (2013) Safety Management Manual (SMM). Doc. 9859. Montreal, Canada. Disponível em: <http://www.icao.int/safety/SafetyManagement/Documents/> Acesso em jun. 2014.

PAGNIN, A. F. (2011) Identificação e caracterização de pterígio utilizando floresta de caminhos ótimos e técnicas de otimização. 2011. 70 f. Dissertação (mestrado) - Universidade Estadual Paulista, Instituto de Biociências, Letras e Ciências Exatas, 2011. Disponível em: <http://hdl.handle.net/11449/108385>.

PAPA, J. P. (2008) Classificação Supervisionada de Padrões Utilizando Florestas de Caminhos Ótimos. Tese de Doutorado, Unicamp. Campinas, SP. Brasil

PAPA, J. P.; FALCAO, A. X.; DE FREITAS, G. M.; DE AVILA, A. (2010) Robust Pruning of Training Patterns for Optimum-Path Forest Classification Applied to Satellite-Based Rainfall Occurrence Estimation. Geoscience and Remote Sensing Letters, IEEE, vol. 7, no. 2, pp. 396, 400, April 2010. doi: 10.1109/LGRS.2009.2037344. 
PAPA, J. P. SPADOTTO, A. A. FAlCAO, A. X. PEREIRA, J. C. (2008) Optimum path forest classifier applied to laryngeal pathology detection. Systems, Signals and Image Processing, IWSSIP 2008. 15th International Conference on vol., no., pp.249, 252, 25-28 June 2008. doi: 10.1109 .

PAPA, J. P. FALCÃO, A. X. LEVADA, A. M. CORRÊA, D. SAlVADEO, D. MASCARENHAS N. D. A. (2009) Fast and accurate holistic face recognition using optimum-path forest. 16th Intl. Conf. on Digital Signal Processing, Santorini, Greece, 2009.

PAPA J. P. SUZUKI C. T. N. FALCÃO, A. X. (2008) LibOPF: A library for the design of optimum-path forest classifiers. Software version 2.0. Disponível em: http://www.ic.unicamp.br/ afalcao/LibOPF

PARA SER PILOTO (Blog). (2013). Bimotores leves: ilusão fatal. Disponível em: <http://paraserpiloto.appa.org.br/> Acesso em: 14 dez. 2015.

PEREIRA, C. R. NAKAMURA, R. Y. M. COSTA, K. A. P., PAPA, J. P. (2012) An Optimum-Path Forest framework for intrusion detection in computer networks. Engineering Applications of Artificial Intelligence. Volume 25, Issue 6, September 2012. Pages 12261234, ISSN 0952-1976.

PEREIRA, M. C., RIBEIRO, S. (2001) Os voos da psicologia no Brasil: Estudos e Práticas na aviação. DAC. NUICAF. Rio de Janeiro.

PERROW, C. (1984) Normal acidentes: living with high-risk Technologies. Princeton, NJ. United States. Princeton University Press.

PIPER (2015) Piper Aircraft, Inc. Disponível em: <http://www.piper.com/> Acesso em 04 mai. 2015

RAFAEL, E. (2013). Bimotores leves: ilusão fatal. Disponível em: <http://www.endersonrafael.com.br/> Acesso em 14 dez. 2015.

RAMOS, C. DE SOUSA, A. N., PAPA, J., FALCAO, A. (2010) A new approach for nontechnical losses detection based on optimum-path forest. IEEE Transactions on Power Systems.

RAMOS, C. C. O. DE SOUZA, A. N. GASTALDELLO, D. S. NAKAMURA, R. Y. M. PAPA, J. P. (2011) Identificação de Perdas Não-Técnicas Utilizando Agrupamento de Dados por Floresta de Caminhos Ótimos. In: X Simpósio Brasileiro de Automação Inteligente. São João del-Rei. X Simpósio Brasileiro de Automação Inteligente.

REASON, J. (1990) Human error. Cambridge University Press.

REASON, J. (1992) Managing the risks of organization accidents. Burlington, UK. Ashgate.

REASON, J. (1995) Understanding adverse events: human factors. Qual. Saf. Health Care. v4. $n^{\circ} 2$. 
REASON, J. (2002) Combating omission errors through task analysis and good reminders. Qual. Saf. Healthcare. $\mathrm{n}^{\mathrm{o}} 11$.

REASON, J. (2005) Safety in the operating thatre - Part 2: Human error and organizational failure. Qual. Saf. Healthcare.

ROCHA, L. M. CAPPABIANCO, F. A. M. FALCÃO, A. X. (2009) Data Clustering as an Optimum-Path Forest Problem with Applications in Image Analysis. Intl. Journal of Imaging Systems and Technology, Wiley, Special Issue: Contemporary Challenges in Combinatorial Image Analysis, Vol. 19, No. 2, pp. 50-68, Jun 2009.

SALGADO, L. H. (2009) Texto para discussão ${ }^{\circ}$ 1388, Estado de uma nação: textos de Apoio, Caos Aéreo e Tragédia dos Comuns: falhas de mercado e de governo, IPEA.

SALGADO, L. H. VASSALLO, M. D. OLIVEIRA, A. V. M. (2010) Regulação, Políticas Setoriais, Competitividade e Formação de Preços: considerações sobre o transporte aéreo no Brasil, Journal of Transport Literature, Vol 4, n.1, pp. 7-48.

SANTI, S. (2009) Fatores Humanos Como Causas Contribuintes Para Acidentes e Incidentes Aeronáuticos na Aviação Geral. Monografia de Especialização. Centro de Formação de Recursos Humanos em Transportes. Universidade de Brasília. Brasília, DF.

SHAPPELL, S. DETWILER, C. HOLCOMB, K. HACKWORTH, C. BOQUET, A. WIEGMANN, D. A. (2007) Human error and commercial aviation accidents: an analysis using the human factor analysis and classification system.

SOUZA, W. A. ALENCAR LOTUFO, R. DE RITTNER L. (2012) Análise comportamental da Optimum-Path Forest em diferentes funções métricas. Monografia.

SPSS. (2010). Statistical package for social sciences, Versão 19.0.0. Chicago, IL: IBM.

STOLT, R. ENSSLIN, L. (2009) Avaliação de pilotos de very light jets utilizando-se a MCDA-C. Rev. Conexão SIPAER. v. 1. n 1. Edição de Lançamento.

UNICAMP (2015) Instituto de Computação. Disponível em: <http://www.ic.unicamp.br/> Acesso em 01 jul. 2015

VIDAL, M. C. (1999) Introdução à ergonomia. Apostila utilizada pelo curso de especialização em Ergonomia Contemporânea da UFRJ.

WOODS, D. D., HOLLNAGEL, E. (2006) Joint Cognitive Systems: patterns in cognitive systems engineering. Boca Raton, United States: CRC Taylor \& Francis.

WIEGMANN, D.; SHAPPELL, S. (1997) Human factors analysis of post-accident data: applying theoretical taxonomies of human error. International Journal of Aviation Psychology.

WIEGMANN, D. A. \& SHAPPEL, S. A. (2001) Human error analysis of commercial aviation accidents: application of the Human Factors Analysis and Classification Systems (HFACS). Aviation, Space, and Environmental Medicine (ASEM). v.72. $\mathrm{n}^{\circ} 11$. 
WIEGMANN, D. A.; SHAPPELL, S. A. (2003) A human error approach to aviation accident analysis: the human factors analysis and classification system. Cornwall: MPG Books Bodmin. 


\section{ANEXO A - Fatores Contribuintes}

Quadro A.1.a - Fatores contribuintes (modificado - Brasil, 2013).

\begin{tabular}{|c|c|c|c|}
\hline $\begin{array}{c}\text { Fatores } \\
\text { Materiais }\end{array}$ & $\begin{array}{c}\text { Fatores } \\
\text { Humanos } \\
\text { Médicos } \\
\end{array}$ & $\begin{array}{l}\text { Fatores Humanos } \\
\text { Psicológicos }\end{array}$ & $\begin{array}{c}\text { Fatores Humanos } \\
\text { Operacionais }\end{array}$ \\
\hline Fabricação & Álcool & Atitude & $\begin{array}{l}\text { Aplicação de } \\
\text { Comandos }\end{array}$ \\
\hline $\begin{array}{l}\text { Manuseio do } \\
\text { Material }\end{array}$ & Ansiedade & Estado Emocional & $\begin{array}{l}\text { Condições } \\
\text { Meteorológicas } \\
\text { Adversas }\end{array}$ \\
\hline Projeto & Desorientação & Motivação Atenção & $\begin{array}{l}\text { Coordenação de } \\
\text { Cabine }\end{array}$ \\
\hline Console & Dieta Inadequada & Percepção & Desvio de Navegação \\
\hline Radar & Disbarismo & Memória & $\begin{array}{l}\text { Esquecimento do } \\
\text { Piloto }\end{array}$ \\
\hline $\begin{array}{l}\text { Serviço } \\
\text { Móvel }\end{array}$ & Dor & Processo Decisório & Indisciplina de voo \\
\hline Tratamento & Enfermidade & Indícios de Estresse & $\begin{array}{l}\text { Influência do meio } \\
\text { ambiente }\end{array}$ \\
\hline \multirow[t]{15}{*}{ Visualização } & Enjoo Aéreo & Comunicação & $\begin{array}{l}\text { Infraestrutura } \\
\text { Aeroportuária }\end{array}$ \\
\hline & Fadiga & Liderança & Instrução \\
\hline & Gravidez & Relações Interpessoais & $\begin{array}{l}\text { Julgamento de } \\
\text { Pilotagem }\end{array}$ \\
\hline & Hiperventilação & Dinâmica de Equipe & $\begin{array}{l}\text { Manutenção de } \\
\text { Aeronave }\end{array}$ \\
\hline & Hipóxia & Influências Externas & Pessoal de Apoio \\
\hline & Ilusões Visuais & $\begin{array}{l}\text { Cultura do Grupo de } \\
\text { Trabalho }\end{array}$ & $\begin{array}{l}\text { Planejamento } \\
\text { Gerencial }\end{array}$ \\
\hline & Inconsciência & Características da Tarefa & Planejamento de Voo \\
\hline & Insônia & Organização do Trabalho & $\begin{array}{l}\text { Pouca Experiência do } \\
\text { Piloto }\end{array}$ \\
\hline & $\begin{array}{l}\text { Intoxicação } \\
\text { Alimentar }\end{array}$ & $\begin{array}{l}\text { Formação, Capacitação e } \\
\text { Treinamento }\end{array}$ & Supervisão Gerencial \\
\hline & $\begin{array}{l}\text { Intoxicação por } \\
\text { CO }\end{array}$ & $\begin{array}{l}\text { Condições Físicas do } \\
\text { Trabalho }\end{array}$ & Carga de Trabalho \\
\hline & Medicamento & $\begin{array}{l}\text { Equipamento - } \\
\text { Características Ergonômicas }\end{array}$ & $\begin{array}{l}\text { Conhecimento de } \\
\text { Normas ATS }\end{array}$ \\
\hline & Obesidade & Sistemas de Apoio & $\begin{array}{l}\text { Coordenação de } \\
\text { Tráfego }\end{array}$ \\
\hline & Próteses & Processos Organizacionais & $\begin{array}{l}\text { Emprego de Meios } \\
\text { (ATS) }\end{array}$ \\
\hline & Ressaca & Clima Organizacional & Equipamento de Apoio \\
\hline & $\begin{array}{l}\text { Sobrecarga de } \\
\text { Tarefas }\end{array}$ & Cultura Organizacional & $\begin{array}{l}\text { Fraseologia da } \\
\text { Tripulação }\end{array}$ \\
\hline
\end{tabular}




\begin{tabular}{|l|l|l|l|}
\hline & $\begin{array}{l}\text { Uso Ilícito de } \\
\text { Drogas }\end{array}$ & $\begin{array}{l}\text { Fraseologia do Órgão } \\
\text { ATS }\end{array}$ \\
\hline & Vertigem & Habilidade de Controle \\
\hline $\begin{array}{l}\text { Vestimenta } \\
\text { Inadequada }\end{array}$ & & Limite de Autorização \\
\hline & & $\begin{array}{l}\text { Planejamento de } \\
\text { Tráfego }\end{array}$ \\
\hline & & Publicações ATS \\
\hline
\end{tabular}




\section{APENDICE A - Teste de Normalidade}

Quadro A.1.b - Teste de Normalidade Kolmogorov-Smirnov ${ }^{14}$ (elaborado pelo autor)

\begin{tabular}{|l|c|c|c|}
\hline & Estatística & df & Sig. \\
\hline Total de Fatores &, 205 & 71 & 0 \\
\hline Total de fatores indeterminados &, 241 & 71 & 0 \\
\hline Nível de qualificação dos pilotos &, 239 & 71 & 0 \\
\hline Experiência recente &, 154 & 71 & 0 \\
\hline Experiência na aeronave do acidente &, 282 & 71 & 0 \\
\hline Experiência total &, 215 & 71 & 0 \\
\hline Experiência recente &, 215 & 71 & 0 \\
\hline Experiência na aeronave do acidente &, 215 & 71 & 0 \\
\hline Experiência total &, 215 & 71 & 0 \\
\hline
\end{tabular}

${ }^{14}$ Após a correção de Lilliefors 


\section{APENDICE B - Coeficiente de Spearman}

Quadro B.1 - Variáveis analisadas pelo Coeficiente de Spearman (elaborado pelo autor)

\begin{tabular}{|c|c|}
\hline Quantidade de Fatores & Fatores Indeterminados \\
\hline Quantidade de Fatores & Qualificação \\
\hline Quantidade de Fatores & Experiência recente \\
\hline Quantidade de Fatores & Experiência na aeronave do acidente \\
\hline Quantidade de Fatores & Experiência Total \\
\hline Fatores Indeterminados & Qualificação \\
\hline Fatores Indeterminados & Experiência recente \\
\hline Fatores Indeterminados & Experiênciência recente \\
\hline Fatores Indeterminados & Experiência Total \\
\hline Qualificação & Experiência na aeronave do acidente \\
\hline Qualificação & Experiência na aeronave do acidente \\
\hline Qualificação & Experiência Total \\
\hline Experiência recente & Experiência Total \\
\hline Experiência recente & \\
\hline Experiência na aeronave do acidente &
\end{tabular}




\section{APENDICE C - Teste U de Mann-Whitney}

Quadro C.1 - Variáveis analisadas pelo Teste U de Mann-Whitney (elaborado pelo autor)

\begin{tabular}{|c|c|}
\hline Copiloto & Quantidade de Fatores \\
\hline Copiloto & Fatores Indeterminados \\
\hline Copiloto & Qualificação \\
\hline Copiloto & Experiência recente \\
\hline Copiloto & Experiência na aeronave do acidente \\
\hline Copiloto & Quantidade de Fatores \\
\hline Fatalidade & Fatores Indeterminados \\
\hline Fatalidade & Qualificação \\
\hline Fatalidade & Experiência recente \\
\hline Fatalidade & Experiência Total \\
\hline Fatalidade & Quantidade de Fatores \\
\hline Fatalidade & Fatores Indeterminados \\
\hline Quantidade de Motores & Qualificação \\
\hline Quantidade de Motores & Experiência recente \\
\hline Quantidade de Motores & Experiência Total \\
\hline Quantidade de Motores & Experiência na aeronave do acidente \\
\hline Quantidade de Motores & Quantidade de Motores \\
\hline
\end{tabular}




\section{APENDICE D - Teste de Qui Quadrado}

Quadro D.1 - Variáveis analisadas pelo Teste de Qui Quadrado (elaborado pelo autor)

\begin{tabular}{|c|c|}
\hline Copiloto & Fatalidade \\
\hline Copiloto & Quantidade de Motores \\
\hline Fatalidade & Quantidade de Motores \\
\hline
\end{tabular}




\section{APENDICE E - Resultados Estatísticos}

Quadro E.1 - Resultados com o Coeficiente de Spearman (elaborado pelo autor)

\begin{tabular}{|c|c|c|c|c|c|c|c|}
\hline & & $\begin{array}{l}\text { Total de } \\
\text { Fatores }\end{array}$ & $\begin{array}{l}\text { Total de Fatores } \\
\text { Indeterminados }\end{array}$ & $\begin{array}{c}\text { Nível de qualificação } \\
\text { dos pilotos }\end{array}$ & $\begin{array}{l}\text { Horas últimos } \\
\text { trinta dias }\end{array}$ & $\begin{array}{c}\text { Experiência na } \\
\text { aeronave do acidente }\end{array}$ & $\begin{array}{l}\text { Experiência } \\
\text { Total - Horas }\end{array}$ \\
\hline \multirow{3}{*}{ Total de Fatores } & Coef. de Correlação & 1,000 &, $669^{* * *}$ & ,078 &,- 076 & ,078 &,- 084 \\
\hline & Sig. (2 caudas) & . &, 000 &, 457 &, 527 &, 515 &, 484 \\
\hline & $\mathrm{N}$ & 93 & 93 & 93 & 71 & 71 & 71 \\
\hline \multirow{3}{*}{$\begin{array}{l}\text { Total de Fatores } \\
\text { Indeterminados }\end{array}$} & Coef. de Correlação &, $669^{* *}$ & 1,000 & ,021 &,- 206 & ,172 &,- 042 \\
\hline & Sig. (2 caudas $)$ &, 000 & . &, 841 &, 084 &, 151 &, 731 \\
\hline & $\mathrm{N}$ & 93 & 93 & 93 & 71 & 71 & 71 \\
\hline \multirow{3}{*}{$\begin{array}{l}\text { Nível de qualificação } \\
\text { dos pilotos }\end{array}$} & Coef. de Correlação & ,078 & ,021 & 1,000 &, 023 &, 042 &, $281^{*}$ \\
\hline & Sig. (2 caudas $)$ & ,457 & ,841 & . & ,846 & ,726 &, 018 \\
\hline & $\mathrm{N}$ & 93 & 93 & 93 & 71 & 71 & 71 \\
\hline \multirow{3}{*}{$\begin{array}{l}\text { Horas últimos trinta } \\
\text { dias }\end{array}$} & Coef. de Correlação &,- 076 &,- 206 &, 023 & 1,000 &,- 022 &,- 022 \\
\hline & Sig. (2 caudas) &, 527 &, 084 & ,846 & . &, 857 &, 857 \\
\hline & $\mathrm{N}$ & 71 & 71 & 71 & 71 & 71 & 71 \\
\hline \multirow{3}{*}{$\begin{array}{c}\text { Experiência na } \\
\text { aeronave do acidente }\end{array}$} & Coef. de Correlação & ,078 &, 172 &, 042 &,- 022 & 1,000 & $370^{* *}$ \\
\hline & Sig. (2 caudas) & ,515 & , 151 & ,726 &, 857 & . &, 002 \\
\hline & $\mathrm{N}$ & 71 & 71 & 71 & 71 & 71 & 71 \\
\hline \multirow{3}{*}{$\begin{array}{c}\text { Experiência Total - } \\
\text { Horas }\end{array}$} & Coef. de Correlação &,- 084 &,- 042 &, $281^{*}$ &,- 022 &, $370^{* *}$ & 1,000 \\
\hline & Sig. (2 caudas) &, 484 &, 731 &, 018 &, 857 &, 002 & . \\
\hline & $\mathrm{N}$ & 71 & 71 & 71 & 71 & 71 & 71 \\
\hline
\end{tabular}

** Correlação é significante com o nível 0.01 (2 caudas)

* Correlação é significante com o nível 0.05 (2 caudas) 
Quadro E.2 - Resultados com o Teste U de Mann-Whitney (elaborado pelo autor)

\begin{tabular}{|c|c|c|c|c|c|c|c|c|c|c|c|c|c|c|c|}
\hline & Copiloto & $\mathbf{N}$ & $\begin{array}{c}\text { Posição } \\
\text { média }\end{array}$ & $\begin{array}{c}\text { Soma } \\
\text { das } \\
\text { posições } \\
\end{array}$ & $\begin{array}{c}\text { Mann- } \\
\text { Whitney } \\
\text { U } \\
\end{array}$ & Fatalidade & $\mathbf{N}$ & $\begin{array}{c}\text { Posição } \\
\text { média }\end{array}$ & $\begin{array}{c}\text { Soma } \\
\text { das } \\
\text { posições } \\
\end{array}$ & $\begin{array}{c}\text { Mann- } \\
\text { Whitney } \\
\text { U } \\
\end{array}$ & $\begin{array}{c}\mathrm{N}^{\circ} \text { de } \\
\text { motores }\end{array}$ & $\mathbf{N}$ & $\begin{array}{l}\text { Posição } \\
\text { média }\end{array}$ & $\begin{array}{c}\text { Soma } \\
\text { das } \\
\text { posições } \\
\end{array}$ & $\begin{array}{c}\text { Mann- } \\
\text { Whitney } \\
\text { U }\end{array}$ \\
\hline \multirow{3}{*}{$\begin{array}{l}\text { Total de } \\
\text { Fatores }\end{array}$} & Não & 88 & 46,02 & 4050,00 & \multirow{3}{*}{134,000} & Não & 55 & 39,15 & 2153,00 & \multirow{3}{*}{613,00} & Mono & 68 & 44,76 & 3044,00 & \multirow{3}{*}{698} \\
\hline & Sim & 5 & 64,20 & 321,00 & & Sim & 38 & 58,37 & 2218,00 & & $\mathrm{Bi}$ & 25 & 53,08 & 1327,00 & \\
\hline & Total & 93 & & & & Total & 93 & & & & Total & 93 & & & \\
\hline \multirow{3}{*}{$\begin{array}{c}\text { Total de } \\
\text { Fatores } \\
\text { Indeterminados }\end{array}$} & Não & 88 & 45,88 & 4037,50 & \multirow{3}{*}{121,50} & Não & 55 & 42,65 & 2346,00 & \multirow{3}{*}{806,00} & Mono & 68 & 43,50 & 2958,00 & \multirow{3}{*}{612} \\
\hline & Sim & 5 & 66,70 & 333,50 & & Sim & 38 & 53,29 & 2025,00 & & $\mathrm{Bi}$ & 25 & 56,52 & 1413,00 & \\
\hline & Total & 93 & & & & Total & 93 & & & & Total & 93 & & & \\
\hline \multirow{3}{*}{$\begin{array}{c}\text { Nível de } \\
\text { qualificação } \\
\text { dos pilotos }\end{array}$} & Não & 88 & 45,67 & 4019,00 & \multirow{3}{*}{103,00} & Não & 55 & 46,33 & 2548,00 & \multirow{3}{*}{1008,00} & Mono & 68 & 41,49 & 2821,50 & \multirow{3}{*}{475,5} \\
\hline & Sim & 5 & 70,40 & 352,00 & & $\mathrm{Sim}$ & 38 & 47,97 & 1823,00 & & $\mathrm{Bi}$ & 25 & 61,98 & 1549,50 & \\
\hline & Total & 93 & & & & Total & 93 & & & & Total & 93 & & & \\
\hline \multirow{3}{*}{$\begin{array}{l}\text { Horas últimos } \\
\text { trinta dias }\end{array}$} & Não & 68 & 36,71 & 2496,00 & \multirow{3}{*}{54,00} & Não & 51 & 33,65 & 1716,00 & \multirow{3}{*}{390,00} & Mono & 50 & 36,48 & 1824,00 & \multirow{3}{*}{501} \\
\hline & Sim & 3 & 20,00 & 60,00 & & $\mathrm{Sim}$ & 20 & 42,00 & 840,00 & & $\mathrm{Bi}$ & 21 & 34,86 & 732,00 & \\
\hline & Total & 71 & & & & Total & 71 & & & & Total & 71 & & & \\
\hline \multirow{3}{*}{$\begin{array}{l}\text { Experiência na } \\
\text { aeronave do } \\
\text { acidente }\end{array}$} & Não & 68 & 35,65 & 2424,00 & \multirow{3}{*}{78,00} & Não & 51 & 35,53 & 1812,00 & \multirow{3}{*}{486,00} & Mono & 50 & 35,04 & 1752,00 & \multirow{3}{*}{477} \\
\hline & Sim & 3 & 44,00 & 132,00 & & Sim & 20 & 37,20 & 744,00 & & $\mathrm{Bi}$ & 21 & 38,29 & 804,00 & \\
\hline & Total & 71 & & & & Total & 71 & & & & Total & 71 & & & \\
\hline \multirow{3}{*}{$\begin{array}{l}\text { Experiência } \\
\text { Total - Horas }\end{array}$} & Não & 68 & 35,29 & 2400,00 & \multirow{3}{*}{54,00} & Não & 51 & 35,53 & 1812,00 & \multirow{3}{*}{486,00} & Mono & 50 & 34,08 & 1704,00 & \multirow{3}{*}{429} \\
\hline & Sim & 3 & 52,00 & 156,00 & & Sim & 20 & 37,20 & 744,00 & & $\mathrm{Bi}$ & 21 & 40,57 & 852,00 & \\
\hline & Total & 71 & & & & Total & 71 & & & & Total & 71 & & & \\
\hline
\end{tabular}


Quadro E.3 - Resultados com o Teste de Qui Quadrado (X²) (elaborado pelo autor)

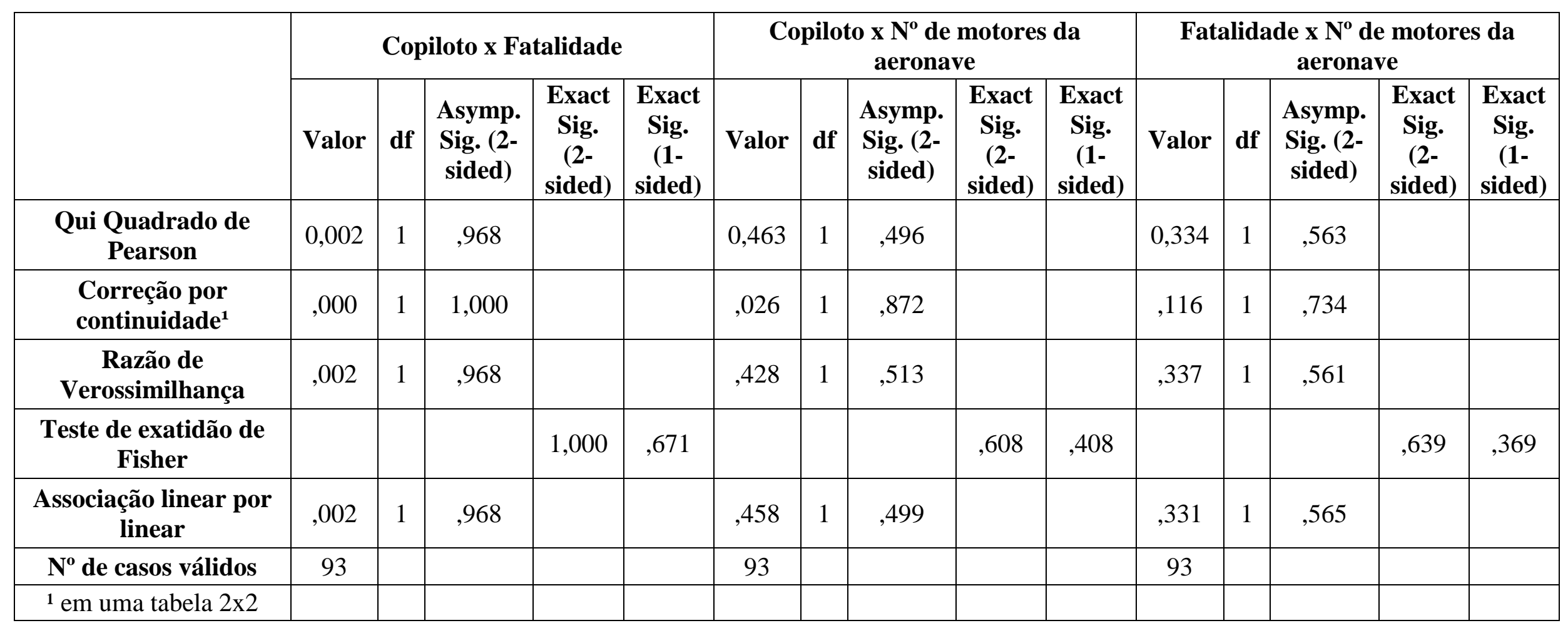

